UNIVERSIDADE DE SÃO PAULO

FACULDADE DE ECONOMIA, ADMINISTRAÇÃO E CONTABILIDADE DE RIBEIRÃO PRETO DEPARTAMENTO DE ADMINISTRAÇÃO

PROGRAMA DE PÓS-GRADUAÇÃO EM ADMINISTRAÇÃ̃O DE ORGANIZAÇÕES

THALES ANDRÉ SILVEIRA SALVETTI

A qualidade do ensino na dimensão da gestão escolar democrática: um estudo de caso na EMEB Alfredo Naime a partir do INDIQUE 
Prof. Dr. João Grandino Rodas

Reitor da Universidade de São Paulo

Prof. Dr. Sigismundo Bialoskorski Neto

Diretor da Faculdade de Economia, Administração e Contabilidade de Ribeirão Preto

Prof. Dr. Marcos Fava Neves

Chefe do Departamento de Administração 


\title{
A qualidade do ensino na dimensão da gestão escolar democrática: um estudo de caso na EMEB Alfredo Naime a partir do INDIQUE
}

\begin{abstract}
Dissertação apresentada ao Programa de PósGraduação em Administração de Organizações da Faculdade de Economia, Administração e Contabilidade de Ribeirão Preto da Universidade de São Paulo como requisito para obtenção do título de Mestre em Ciências.
\end{abstract}

Orientadora: Profa. Dra . Cláudia Souza Passador

* Versão corrigida da Dissertação. A original encontra-se disponível no Serviço de Pós-Graduação da FEA-RP/USP. 
Autorizo a reprodução e divulgação total ou parcial deste trabalho, por qualquer meio convencional ou eletrônico, para fins de estudo e pesquisa, desde que citada a fonte.

FICHA CATALOGRÁFICA

Salvetti, Thales André Silveira

A qualidade do ensino na dimensão da gestão escolar democrática: um estudo de caso na EMEB Alfredo Naime a partir do INDIQUE. Ribeirão Preto, 2011.

98 p.: il. ; $30 \mathrm{~cm}$

Dissertação de Mestrado apresentada à Faculdade de Administração, Economia e Contabilidade de Ribeirão Preto/USP. Área de concentração: Administração de Organizações.

Orientadora: Passador, Cláudia Souza.

1. Administração. 2. Gestão escolar democrática. 3. Qualidade de ensino. 4. Estudos Organizacionais Críticos. 5. Indicadores da Qualidade na Educação. 
Dedico este trabalho à minha mãe, Vera, e meu pai, Antônio Paulo, em memória, por tudo o que foram capazes de fazer por mim e pelo orgulho que sentiriam ao ver este meu trabalho realizado 


\section{FOLHA DE APROVAÇÃO}

Nome: SALVETTI, Thales André Silveira

Título: A qualidade do ensino na dimensão da gestão escolar democrática: um estudo de caso na EMEB Alfredo Naime a partir do INDIQUE.

Dissertação apresentada ao Programa de PósGraduação em Administração de Organizações da Faculdade de Economia, Administração e Contabilidade de Ribeirão Preto da Universidade de São Paulo como requisito para obtenção do título de Mestre em Ciências.

Aprovada em: $\underline{31}$ / 10 / 2011

Banca Examinadora

Prof. Dr. Instituição:

Julgamento: Assinatura:

Prof. Dr. Instituição:

Julgamento: Assinatura:

Prof. Dr. Instituição: Assinatura: 


\section{AGRADECIMENTOS}

À minha professora e orientadora Cláudia Souza Passador, pela enorme liberdade que me permitiu na elaboração deste trabalho, pelo apoio da bolsa, fundamental num momento tão delicado e importante da minha vida e pela paciência comigo.

Ao Zé Marcelino e ao grupo GEG, de pessoas tão especiais, que muito me ajudaram na busca e discussão de conteúdos para este trabalho e para a vida.

À Teise Oliveira, por sua correção minuciosa e contribuição crítica, que foram essenciais a esta dissertação.

Aos integrantes do grupo de estudos GPublic, pelas contribuições e altruísmo.

À minha esposa Maisa, por suas maneiras inegoístas de me amar, sem as quais este trabalho não teria sido.

À minha família, que me apoia e torce por mim.

Aos meus amigos, marcantes na minha vida.

Aos profissionais e à comunidade da EMEB Alfredo Naime, que me receberam muito bem e fazem naquela escola um trabalho admirável.

Ao Observatório Nacional da Educação (MEC/CAPES/INEP), pelo imprescindível suporte financeiro a este estudo. 


\section{RESUMO}

SALVETTI, T.A.S. A qualidade do ensino na dimensão da gestão escolar democrática: um estudo de caso na EMEB Alfredo Naime a partir do INDIQUE. 2011. 98f. Dissertação (Mestrado) - Faculdade de Economia, Administração e Contabilidade de Ribeirão Preto, Universidade de São Paulo, Ribeirão Preto, São Paulo, 2011.

A gestão escolar democrática é tida como elemento imprescindível à qualidade do ensino por vários autores e profissionais da educação. Entretanto, há também por parte deles o reconhecimento da enorme distância entre um ideal democrático de administração escolar e a realidade, especialmente neste caso, a brasileira. Tendo em vista a notória relevância desse tema para o cenário nacional de educação e ensino, este estudo teve por objetivo analisar essa dimensão da qualidade a partir do estudo de caso na Escola Municipal de Educação Básica Alfredo Naime, do município de Bebedouro, a qual passou pelos processos de avaliação propostos no INDIQUE (2009), elaborados pela parceria entre: Ação Educativa, UNICEF, PNUD, INEP e MEC, os quais correspondiam científica e metodologicamente aos anseios desta pesquisa. Para a análise foram utilizadas informações do Plano Gestor da escola e principalmente do relatório gerado pelo processo do INDIQUE na escola. Também foram feitos acompanhamentos de atividades escolares assim como entrevistas semi-estruturadas e não-estruturadas a todos os principais atores da instituição de ensino (alunos, pais, professores, gestores e funcionários) a fim de colher opiniões e perspectivas dos entrevistados sobre o tema. Concluiu-se que, apesar de restrições principalmente externas, mas também internas, a uma gestão escolar democrática, os atores escolares da EMEB Alfredo Naime mostraram que rumam a uma gestão democratizante. A outra principal conclusão diz respeito ao INDIQUE, que se mostrou um rico instrumento de avaliação coletiva efetivamente democrático e contribuidor para a escola em diversas dimensões educacionais.

Palavras-chave: Administração. Gestão escolar democrática. Qualidade de ensino. Estudos Organizacionais Críticos. Indicadores da Qualidade na Educação (INDIQUE). 


\begin{abstract}
SALVETTI, T.A.S. The educational quality in democratic school management dimension: a case study in Municipal School Alfredo Naime from INDIQUE. 2011. $98 f$. Dissertation (Master's Program) - Faculdade de Economia, Administração e Contabilidade de Ribeirão Preto, Universidade de São Paulo, Ribeirão Preto, São Paulo, 2011.

The democratic school management is seen as an indispensable element of educational quality by several authors and education professionals. However, they also recognize the enormous gap between a democratic ideal and the reality of school administration, especially in this case, the Brazilian situation. Given the evident importance of this issue to the national arena of education and teaching, this study aimed to analyze this dimension of quality from the case study at the Municipal School of Basic Education Alfredo Naime, from the city of Bebedouro, which has passed by the assessment procedures proposed in the INDIQUE (2009), prepared by the partnership: Educational Action, UNICEF, UNDP, INEP and MEC, which corresponded to the scientifically and methodologically perspectives of this research. For the analysis were used information of the Plan Manager of the school and especially the report generated by the Educational Quality Indicators process in the school. Were also made follow-school activities as well as semi-structured and unstructured interviews to all major actors from the school (students, parents, teachers, managers and employees) in order to collect opinions and perspectives of those interviewed on the subject. It was concluded that, despite restrictions mainly external, but internal too, to a democratic school management, the school actors of Municipal School Alfredo Naime showed that tend to a democratizing management. The other main finding relates to Educational Quality Indicators, that proved to be a rich collective assessment tool, effectively democratic and contributor to the school in various dimensions of education.
\end{abstract}

Key words: Administration. Democratic school management. Educational quality. Critical Organization Studies. Educational Quality Indicators (INDIQUE). 


\section{LISTA DE QUADROS}

Quadro 1 - Dados da Escola Municipal de Educação Básica "Alfredo Naime". .15

Quadro 2 - Organização da escola .................................................................16

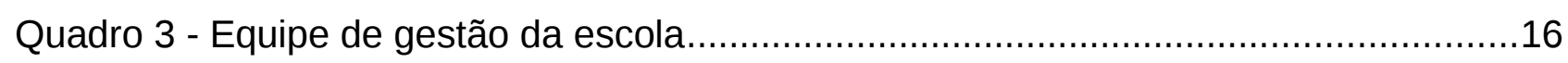

Quadro 4 - Dependências da escola..........................................................17

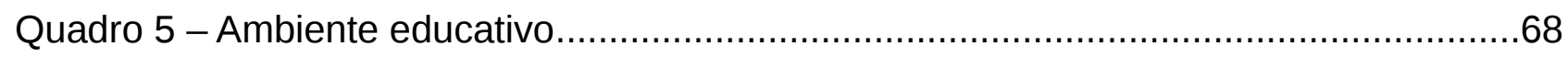

Quadro 6 - Ensino e aprendizagem da escrita e da leitura ....................................70

Quadro 7 - Prática pedagógica e avaliação......................................................... 71

Quadro 8 - Gestão escolar democrática........................................................... 72

Quadro 9 - Formação de condições de trabalho dos profissionais da escola...................73

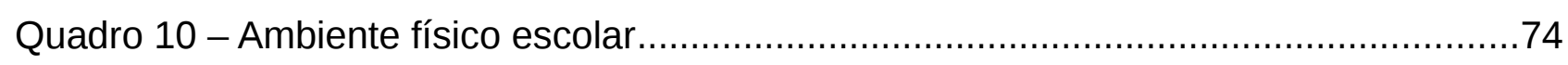




\section{GLOSSÁRIO}

APM Associação de pais e mestres

CAPES Coordenação de Aperfeiçoamento de Pessoal de Nível Superior

CAQi Custo Aluno Qualidade inicial

CENPEC Centro de Estudos e Pesquisas em Educação, Cultura e Ação Comunitária

DEMEC Departamento Municipal de Educação e Cultura

EMEB Escola Municipal de Educação Básica

EOC Estudos Organizacionais Críticos

FUNDEB Fundo de Manutenção e Desenvolvimento da Educação Básica

FUNDEF Fundo de Manutenção e Desenvolvimento do Ensino Fundamental

GPublic Centro de Estudos em Gestão e Políticas Públicas Contemporâneas

HTPC Horário de trabalho pedagógico coletivo

INDIQUE Indicadores da Qualidade na Educação

INEP Instituto Nacional de Estudos e Pesquisas Educacionais Anísio Teixeira

LDB Lei de Diretrizes e Bases da Educação Nacional

MEC Ministério da Educação

OEP Oficina de Ensino e Pesquisa

PCN Parâmetros Curriculares Nacionais

PDE Plano de Desenvolvimento da Educação

PDDE Programa Dinheiro Direto na Escola

PNUD Programa das Nações Unidas para o Desenvolvimento

PNE Plano Nacional da Educação

PPP Projeto Político Pedagógico

SAEB Sistema de Avaliação da Educação Básica

SARESP Sistema de Avaliação do Rendimento Escolar do Estado de São Paulo

SEADE Fundação Sistema Estadual de Análise de Dados

SP São Paulo

Unicef Fundo das Nações Unidas para a Infância 


\section{Sumário}

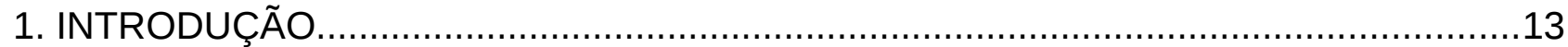

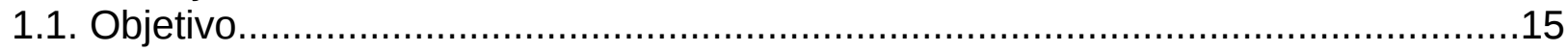

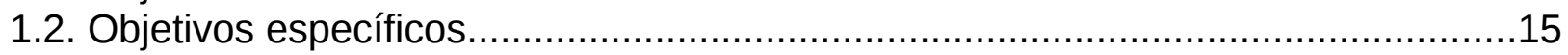

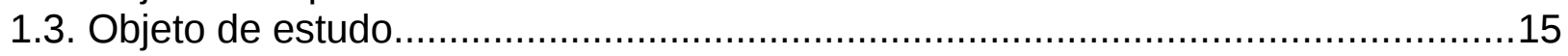

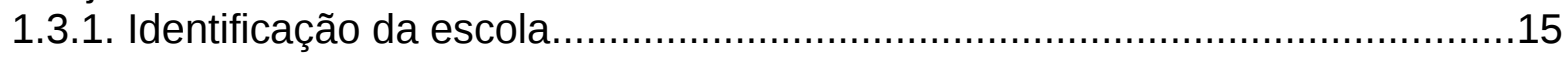

1.3.2. Breve histórico da escola............................................................... 18

1.3.3. Perfil municipal de Bebedouro.................................................... 19

Quadro 5 - Perfil Municipal de Bebedouro................................................................. 19

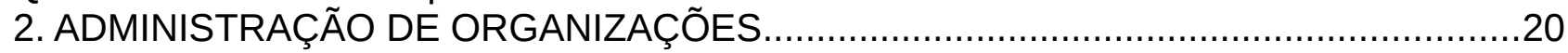

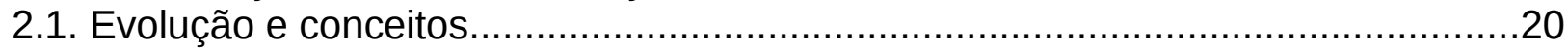

2.2. Gestão Pública - ênfase Brasil.............................................................. 29

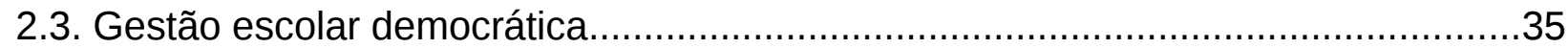

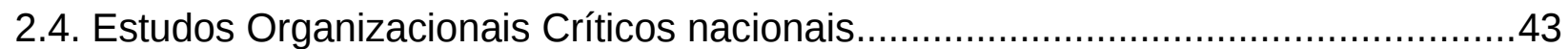

3. QUALIDADE EM EDUCAÇÃO ESCOLAR - ÊNFASE BRASIL $\ldots \ldots \ldots \ldots \ldots \ldots \ldots \ldots \ldots \ldots . \ldots \ldots$

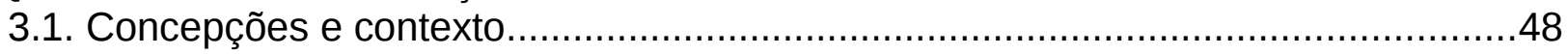

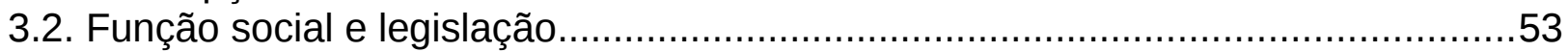

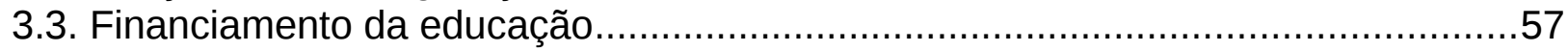

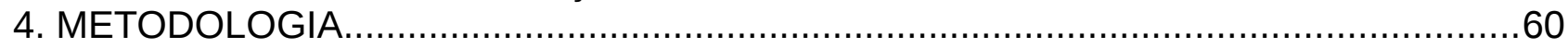

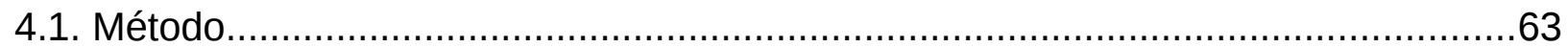

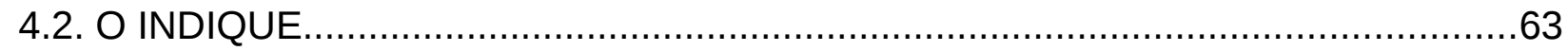

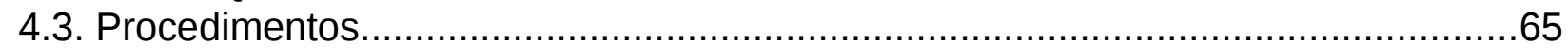

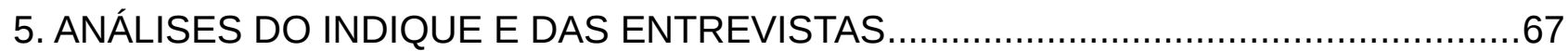

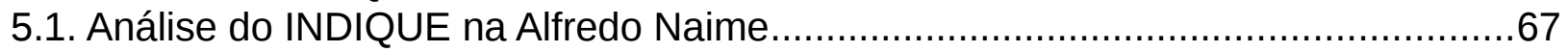

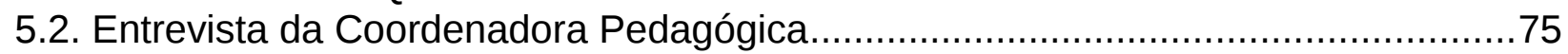

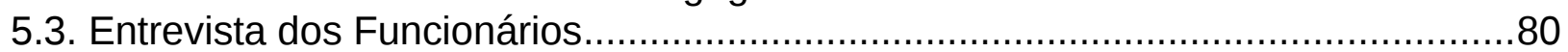

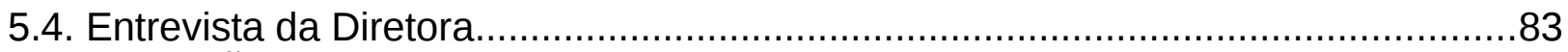

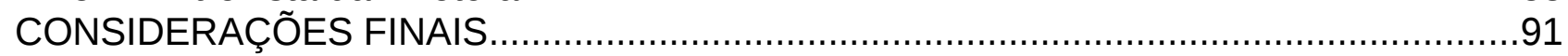

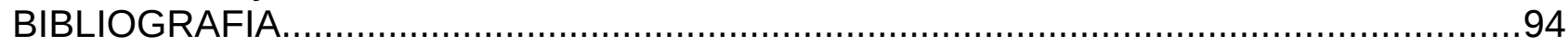

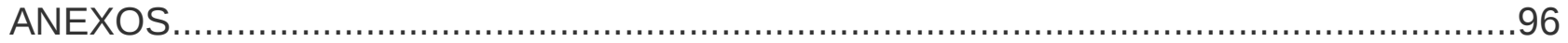




\section{INTRODUÇÃO}

As escolhas contidas neste trabalho se apresentam entre razões pragmáticas e angústias teórico-práticas para os campos da administração e da educação, resguardadas as circunstâncias acadêmicas.

No que se refere a motivos mais objetivos, a decisão pelo tema procura se inserir num projeto maior, do qual fazem parte a docente orientadora e o discente autor deste estudo (na área de "indicadores de desempenho dos sistemas de ensino; determinantes da qualidade de ensino"), proveniente de um programa de fomento "que visa ao desenvolvimento de estudos e pesquisas na área de educação" chamado "Observatório da Educação", fruto de uma parceria entre o Ministério da Educação (MEC), a Coordenação de Aperfeiçoamento de Pessoal de Nível Superior (CAPES) e o Instituto Nacional de Estudos e Pesquisas Educacionais Anísio Teixeira (INEP) (INEP, 2010).

Já em relação às angústias foram duas as questões aqui problematizadas: a primeira vem da tentativa de levantar e estabelecer relações teóricas consistentes, entre determinadas teorias da administração de organizações e da qualidade da educação escolar, que embasem e deem corpo à compreensão sobre as significações e entendimentos aqui almejados para o tema "gestão escolar democrática", o qual se constitui em foco da pesquisa, é inseparável da questão da qualidade no ensino e tem por característica esse hibridismo, essa interdisciplinaridade entre os já citados campos da administração e da educação, lembrando Paro (2007). A segunda diz respeito aos anseios pela possibilidade de interferência no processo e objeto de pesquisa, que permita ao trabalho possuir um caráter de projeto de pesquisa e extensão, para fugir do que é comum para muitos cursos universitários, onde as academias diplomam todos os anos centenas de novos bacharéis que só excepcionalmente farão uso, na vida prática, dos ensinamentos recebidos durante o curso, interpretando Holanda (1986, p.115).

Assim, o segundo capítulo intitulado "administração de organizações", em seu primeiro tópico "evolução e conceitos", procurou percorrer os trajetos históricos das teorias da administração, demonstrando postura crítica a seus conteúdos mais difundidos ao longo do tempo e sugerindo uma visão coletivista, efetivamente participativa e politizada a ser adotada pelas organizações em detrimento da visão produtivista amplamente em vigor no mundo, resumindo Motta (2001). E foi essa a ideia sobre administração que acompanhou este trabalho sobre o elemento "gestão" do seu título. O outro tópico de nome "gestão pública - ênfase Brasil" buscou fazer uma contextualização 
histórica ligando-se ao capítulo seguinte no sentido de trazer à tona o fato de que a atual conjuntura do sistema educacional brasileiro é indissociável de sua herança cultural, de sua evolução econômica e da estruturação de seu poder político (Romanelli, 1978). O terceiro tópico desse capítulo tratou da questão mais específica da gestão escolar, numa perspectiva democrática, de modo também a definir a acepção desses termos para este estudo, deixando ainda mais evidentes ao leitor os pontos de vista sob os quais se fizeram as análises sobre a qualidade do ensino na dimensão da gestão escolar democrática. No quarto tópico almejou-se suscitar a relação entre as teorias organizacionais e as teorias educacionais sobre gestão escolar democrática apresentadas até então.

No terceiro capítulo sobre a qualidade em educação procurou-se o aprofundamento na questão da qualidade educacional e suas dimensões. Nele, além de se ter pretendido explicar a ideia sobre qualidade de ensino que será conduzida neste estudo, salientaramse dois elementos de sua composição, os objetivos e os subjetivos. As questões consideradas mais subjetivas encontram-se nos dois primeiros tópicos ("concepções e contexto" e "função social e legislação"), em que o intento foi de enquadrar o assunto ao cenário nacional entre concepções, institucionalidade legal e função (ou finalidade) social, tomados por fundamentais a essa tarefa. O outro tópico desse capítulo, "financiamento da educação", abordou algumas das condições objetivas do ensino - tidas como pertinentes à pesquisa - visto que são também essenciais à gestão escolar e à qualidade educacional, conforme visto em Demo (2007).

O quarto capítulo tem a intenção de prover sustentação científico-metodológica para o estudo e também justificar e caracterizar rumos e escolhas, assim como detalhar os métodos e procedimentos que foram utilizados nesta pesquisa.

O quinto capítulo contém as análises das entrevistas feitas durante a pesquisa, com os respectivos atores escolares, e a análise sobre o relatório do Plano de Ação resultante do processo do INDIQUE na EMEB Alfredo Naime.

\subsection{Objetivo}

O objetivo deste trabalho foi analisar a qualidade da educação escolar, na dimensão da gestão democrática, por meio de um estudo de caso na EMEB Alfredo Naime, do município de Bebedouro, a qual passou pelo INDIQUE. 


\subsection{Objetivos específicos}

O objetivo deste trabalho pode ser melhor visualizado a partir da seguinte ordenação sistemática de objetivos mais específicos, em que os propósitos foram de:

- Elaborar um referencial teórico de perspectivas convergentes sobre gestão, tanto para o campo da Administração quanto para a Educação.

- Analisar o relatório e os possíveis impactos na escola do processo gerado pelo INDIQUE.

- Captar e analisar compreensões e opiniões dos atores escolares sobre esses assuntos.

- Construir considerações conclusivas dessas análises, permeadas por aquilo que foi trazido no referencial teórico, que possam gerar contribuições para a escola.

\subsection{Objeto de estudo}

Este tópico informa o leitor a respeito dos dados e fornece um breve histórico da Escola Municipal de Educação Básica Alfredo Naime. Serve também para ilustrar algumas das características gerais da escola e da sua região visando melhor compreensão do objeto de estudo e seu contexto.

\subsubsection{Identificação da escola}

\begin{tabular}{|l|l|}
\hline \multicolumn{2}{|l|}{ Quadro 1 - Dados da Escola Municipal de Educação Básica “Alfredo Naime" } \\
\hline Endereço & Rua Luiz Mambelli 490, Povoado de Andes, Bebedouro/SP \\
\hline Telefone & (17) 3349-1110 - (17) 3349-1128 \\
\hline E-mail & $\underline{\text { alfredonaime@bebedouro.sp.gov.br }}$ \\
\hline Mantenedor & Prefeitura Municipal de Bebedouro \\
\hline
\end{tabular}




\begin{tabular}{|l|l|}
\hline Data de criação da escola & Decreto Estadual de 1982 \\
\hline Data de instalação da escola & Resolução SE de 1982 \\
\hline Patronímico/denominação & Decreto Estadual de 1982 \\
\hline Municipalização & Decreto Municipal de 2000 \\
\hline Transformação em EMEB & Decreto Municipal de 2003 \\
\hline Transformação em escola de tempo integral & Decreto Municipal de 2008 \\
\hline
\end{tabular}

Fonte: Plano Gestor 2008/2011 da EMEB Alfredo Naime. DEMEC, 2008.

\begin{tabular}{|l|l|}
\hline \multicolumn{2}{|c|}{ Quadro 2 - Organização da escola } \\
\hline Etapa & Educação Básica \\
\hline Níveis & Infantil e Fundamental \\
\hline Modalidades & Infantil, 1ํㅜ e $2^{a}$ etapas / Fundamental, Ciclo I e Ciclo II \\
\hline Período de atividade & Manhã (07:00h às 11:30h) e Tarde (12:30h às 17:50h) \\
\hline
\end{tabular}

Fonte: Plano Gestor 2008/2011 da EMEB Alfredo Naime. DEMEC, 2008.

\begin{tabular}{|l|l|}
\hline \multicolumn{2}{|c|}{ Quadro 3 - Equipe de gestão da escola } \\
\hline Diretora & Prof $^{a}$ Sueli Aparecida Occaso Latorre \\
\hline Coordenadora & Prof $^{\underline{a}}$ Luciana Felizardo Andrade \\
\hline
\end{tabular}

Fonte: Plano Gestor 2008/2011 da EMEB Alfredo Naime. DEMEC, 2008. 


\begin{tabular}{|c|c|c|}
\hline \multicolumn{3}{|c|}{ Quadro 4 - Dependências da escola } \\
\hline Qtde. & Tipo de dependência & $\mathrm{m}^{2}$ \\
\hline 1 & Almoxarifado & 11,85 \\
\hline 1 & Cantina & 7,5 \\
\hline 1 & Cozinha & 16,5 \\
\hline 1 & Despensa & 7,5 \\
\hline 1 & Diretoria & 21,8 \\
\hline 1 & Gabinete dentário & 9 \\
\hline 1 & Laboratório de informática & 36 \\
\hline 1 & Pátio coberto & 220,1 \\
\hline 1 & Pátio descoberto & 1232,5 \\
\hline 5 & Salas de aula & 36 \\
\hline 1 & Sala de leitura & 21,5 \\
\hline 1 & Sala de professores & 21,8 \\
\hline 1 & Sala de aula para Educação Infantil & 36 \\
\hline 2 & Sanitários Adm. & 8,91 \\
\hline 2 & Sanitários alunos & 5,4 \\
\hline 1 & Secretaria & 13,62 \\
\hline 2 & Vestiários & 13,62 \\
\hline
\end{tabular}

Fonte: Plano Gestor 2008/2011 da EMEB Alfredo Naime. DEMEC, 2008.

\subsubsection{Breve histórico da escola}

A citação a seguir consta no Plano Gestor 2008/2011, que é um conjunto de intenções, propostas e cursos de ações administrativas e pedagógicas para a escola num período de três anos, elaboradas principalmente pela diretoria a partir do levantamento de dados e pesquisas feitas detalhando as atividades pretendidas e em andamento na EMEB 
Alfredo Naime, registrado no Departamento Municipal de Educação e Cultura de Bebedouro, onde há também um recorte do levantamento da história que vem sendo feito pela escola com os alunos, junto de suas famílias, para resgatar as origens não apenas da escola, mas também do próprio Povoado de Andes e sua pequena população de aproximadamente 400 habitantes, o qual é um distrito do município de Bebedouro/SP.

Na década de vinte do século passado, havia no Povoado de Andes uma classe multisseriada de $1^{\mathrm{a}}$ e $2^{\mathrm{a}}$ série que funcionava onde, atualmente, é o bar do Gabriel Barbato. Neste local, as crianças da época estudavam e, quando podiam, prosseguiam seus estudos nas cidades vizinhas como Taiuva e Bebedouro e, para tanto, utilizavam como meio de transporte o trem.

Um dos comerciantes da época, o Sr. Alfredo Naime, percebendo que no lugar havia um grande número de analfabetos, verificou a necessidade da construção de um grupo escolar e saiu à luta para conseguí-lo.

(...) Em 1948, o grupo escolar da Estação de Andes recebeu sua primeira turma de formandos, vindo de escolas estaduais e cidades vizinhas e também seu $1^{\circ}$ diretor o Sr. Sérvulo Gonçalves Sobrinho. Neste mesmo ano concluiu-se a $1^{\text {a }}$ classe da $4^{a}$ série da escola e destes alunos, residem ainda no Povoado a Sra. Alice Bernardes e Inez Santos Bugalho.

Os anos passaram-se e houve uma diminuição do número de crianças da região matriculadas na escola e devido a isso as classes foram organizadas em multisseriadas e também não mais contava com direção, permanecendo assim por um bom tempo.

No ano de $1982 \ldots$ o grupo passou a ter novamente o serviço de direção escolar... e passou a ter a denominação de E.E.P.G. (Agrupada) Alfredo Naime... Neste mesmo ano foi criada uma classe de $5^{\text {a }}$ série contava com 17 (dezessete) alunos, dentre os quais fazem parte do corpo docente atual desta escola a diretora Sueli Aparecida Occaso e a professora Elisabete de Cássia Vechiato dos Santos que responde pelo Projeto Adote uma Escola.

(...) Em 2000, o município assumiu o ensino fundamental da várias Unidades escolares dentre elas a escola Alfredo Naime...

(...) Hoje atendemos a Educação Básica, na modalidade de Ensino Fundamental de 9 anos de duração, implantando progressivamente a partir de 2006... hoje com $1^{\circ}, 2^{\circ}$ e $3^{\circ}$ anos (Ciclo I - A) e Ensino Fundamental de 8 anos com $3^{\mathrm{a}}$ e $4^{\mathrm{a}}$ séries do ciclo I - B e $5^{\mathrm{a}}, 6^{\mathrm{a}}, 7^{\mathrm{a}}$ e $8^{\mathrm{a}}$ séries do ciclo II, e contamos ainda com uma classe multisseriada ( $1^{\mathrm{a}}$ e $2^{\mathrm{a}}$ etapa) da Educação Infantil. Temos 16 professores, sendo um de educação infantil, cinco de ensino fundamental I e 10 de ensino fundamental II. Contamos ainda com três funcionários que cuidam da limpeza e fazem refeições e merendas dos alunos, com três estagiários que auxiliam na secretaria e salas de aula, um escriturário, um coordenador pedagógico e um diretor.

(...) Formamos uma comunidade heterogênea e atendemos alunos do Povoado, mas a maioria é da zona rural, filhos de trabalhadores e para chegarem à escola utilizam transporte escolar, o qual é realizado pelo Departamento de Transporte da Prefeitura Municipal de Bebedouro (DEMEC, 2008).

\subsubsection{Perfil municipal de Bebedouro}

A seguir, um resumo com indicadores do município de Bebedouro para melhor situar o leitor a respeito das características da região do objeto de estudo. 


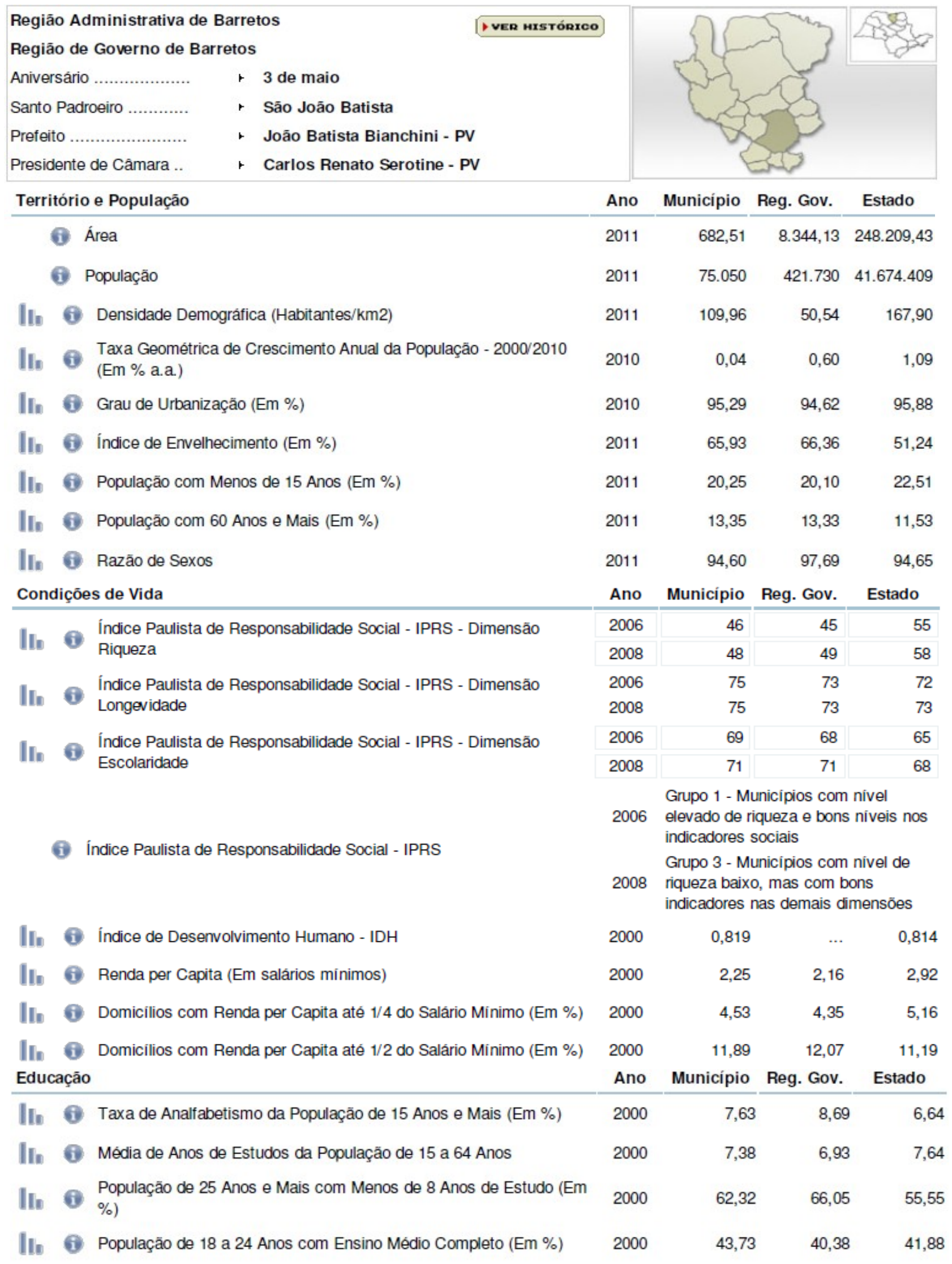

Fonte: Fundação Sistema Estadual de Análise de Dados. SEADE (2011) 


\section{ADMINISTRAÇÃO DE ORGANIZAÇÕES}

\subsection{Evolução e conceitos}

A identidade das teorias de administração, sejam elas observadas enquanto empresariais, públicas, educacionais ou de qualquer outro tipo, possui raízes num único elemento, que é a preocupação com a produtividade, característica esta que aparece com maior intensidade a partir do longo processo de Revolução Industrial, o qual implica em mudanças radicais na cultura material do Ocidente, transformando a relação do ser humano com a natureza, com o trabalho e consequentemente com todas as outras esferas de ação humana, em maior ou menor grau (Motta, 2001, p.3).

O pano de fundo dos eventos e teorias organizacionais do período que vai do século XIX à segunda guerra mundial deve incluir uma análise pautada na observação dos principais quadros institucionais dessa época, ou seja, aqueles que foram historicamente mais influentes tanto em âmbito nacional quanto em âmbito internacional para que se possa entender suas consequências no século $X X$ e $X X I$, explica Motta (2001). Essas instituições de base seriam "o sistema de equilíbrio de poder entre as então Grandes Potências, o padrão internacional de ouro como base de uma organização única, o mercado auto-regulável e o Estado liberal". Algumas ressalvas estão na passagem posterior do lastro ouro para o lastro dólar como parâmetro mundial, no distanciamento, em termos administrativos, entre os setores público e privado, em que este último ganha maior autonomia em relação ao outro, e na transformação do papel do Estado no que diz respeito ao trabalho, já que transmite a função de maior empregador de mão-de-obra para os industriais e mais adiante para todo o setor privado, sendo assim falsa a visão de liberdade de trabalhar, visto que os patrões são trocados, mas não a necessidade de trabalho sob as condições destes. A peça-chave desse sistema era o mercado autoregulável, que trazia consigo uma "contradição fundamental", já que contribuiu por certo tempo nas relações entre as grandes nações, mas não foi capaz de prolongar sua existência, pois implicava na "subordinação do homem ao mercado" e sua produtividade, o que causou uma "destruição das formas orgânicas de existência", substituindo-as por uma nova forma de organização, de "natureza individualista e atomizada" (Id. Ibid., p.54).

Todavia, lembrando Weber (2007, p.61), todas essas mudanças nas relações econômicas e institucionais decorrentes do capitalismo não teriam se firmado caso não 
houvesse condições culturais, morais e psicológicas que acompanhassem essas transformações. Para assumir trabalhos muito mais intensos, agora exigidos dos empresários e que raramente são compatíveis com um "fácil gozo da vida", são necessárias "qualidades éticas bem definidas e marcantes" que Ihes permitirão angariar a confiança indispensável de clientes e funcionários além de Ihes fornecer energia suficiente para superar inúmeras resistências, qualidades estas como clarividência, capacidade de ação, audácia, visão, ponderação e "princípios rigorosamente burgueses", reúnem-se em torno da aclamada determinação, ou devoção à causa, uma busca incansável por um objetivo distante, irracional, sem sentido, de conquistas sem fim, onde há uma inversão de valores de conduta de vida, em que "o ser humano existe para o seu negócio e não o contrário". Essas condições são fruto, em boa parte, de uma "ética protestante" que alicerça e incorpora o "espírito capitalista" à moral religiosa, notadamente na Inglaterra e nos Estados Unidos, onde se difundiram em maior escala e profundidade. A ética protestante será responsável por trazer novos valores fundamentais muito mais adequados à vida burguesa e à propagação desta em relação àqueles pregados pelo catolicismo, como a visão não pecaminosa, e até virtuosa, do lucro (Id. Ibid.).

Entre os precursores das teorias da administração, diz Motta (2001, p.5), estão Saint-Simon, cuja proposta de filosofia normativa em oposição à filosofia especulativa antecede os conceitos de planejamento e racionalização do trabalho. Outro que recebe destaque é Charles Fourier, que premedita uma reconstrução da sociedade ocidental para adequar sua cultura não-material, característica fortemente religiosa, aos avanços da cultura material. Já Robert Owen é enfatizado principalmente por suas experiências altamente inovadoras e prósperas, por certo tempo, à época, em termos de organização e regimentação de suas empresas, como a redução de jornada de trabalho, a abolição de crianças menores de dez anos nas suas fábricas e a substituição de castigos por advertências. Por fim Louis Blanc também aparece como precursor por suas obras e ideias, nas quais defendia ser possível a construção de uma sociedade igualitária a partir do Estado mesmo em moldes fabris de produção, o que inspirou futuras cooperativas de produtores em séculos seguintes.

Os autores apontados por Motta, entre outros de épocas próximas, como Karl Marx, além de precursores, dividem a característica de terem elaborado teorias de caráter totalizador e global, diferentemente dos teóricos tidos como clássicos da administração, entre eles Taylor e Fayol, os quais trazem à tona as "teorias microindustriais de alcance médio", acompanhando o aumento da dimensão da empresa e definindo a substituição do 
“capitalismo liberal pelos monopólios" (Tragtenberg, 1992, p.70).

Motta (2001, p.7) diz que os pioneiros da Administração Clássica, em especial Frederick Winslow Taylor, construíram conceitos fortemente voltados para a racionalização dos métodos e sistemas de trabalho em detrimento da organização do trabalho. O homem, nesse ínterim, seria um sujeito capaz de maximizar suas decisões, entendendo-se estas em termos de maiores ganhos econômicos, os quais norteavam seus valores. Assim sendo, o homem buscava "um máximo de ganhos com um mínimo de esforços". Cabia ao administrador, portanto, segundo Maximiano (2004a, p.49), direcionar esses esforços de maneira racional, conforme definiu Henry Fayol em suas famosas classificações micro-burocráticas das funções do administrador: "planejar, organizar, coordenar, comandar e controlar", salientando os princípios de unidade de comando, de divisão do trabalho, de especialização e de amplitude de controle. "Esses princípios referem-se às formas estruturais dominantes em nossa sociedade". Reforçam a argumentação do peso e influência desses princípios, ainda muito presentes nas organizações atuais, as afirmações encontradas em livros recentes de Teoria Geral de Administração, como as de Maximiano (2004a, p.26), de que em qualquer organização social, independentemente da sua complexidade ou essência, haverá um processo de administrar, já que este é inerente a qualquer situação onde haja pessoas que utilizam recursos para atingir algum tipo de objetivo. Ele ainda explica que esse processo administrativo fundamenta-se em tomar e colocar em prática decisões sobre objetivos (resultados esperados do sistema) e utilização de recursos (pessoas, informação, conhecimento, espaço, tempo, dinheiro e instalações). As decisões assinaladas pelo autor possuem quatro funções principais: "de planejamento, que definem as diretrizes e os recursos; de organização, que dispõem os recursos em uma estrutura; de execução, que realizam os planos e; de controle, que verificam resultados".

Vale lembrar, contudo, que esse descolamento com as realidades, essa ideologização da administração científica e sua repercussão não são de todo determinantes em termos organizacionais mundiais ou brasileiros, mas a ênfase e a escala de reprodução dadas a essas escolas de pensamento que justificam, em parte, a generalização do uso desses termos (Motta, 2001).

Tragtenberg (1992, p.89) é mais enfático em relação à ideologia das teorias administrativas, afirmando que:

A Teoria Geral da Administração é ideológica, na medida em que traz em si a ambiguidade básica do processo ideológico, que consiste no seguinte: vincula-se 
ela às determinações sociais reais, enquanto técnica (de trabalho industrial, administrativo, comercial) por mediação do trabalho; e afasta-se dessas determinações sociais reais, compondo-se num universo sistemático organizado, refletindo deformadamente o real, enquanto ideologia.

Freire (2006, p.106) aponta a contradição dos "mecanicistas dogmáticos, autoritários", em refutarem esse aspecto idealista da propagação do saber - aqui referente às teorias administrativas - pois essa postura também é ideológica, na medida em que é proibitiva à criticidade, em que se utiliza como saída a "sloganização" política, ou seja, uma simplificação pouco racional desta, que não é afeita ao debate, à curiosidade e, principalmente, à contestação e que, ao mesmo tempo, compõe-se como linguagem própria, desprovida da semântica dos grupos populares, mas carregada em leituras elitistas dos grupos dominantes.

O rompimento de paradigma da ciência social vigente pertinente às organizações ocorre com o funcionalismo, cujos postulados opõem: uma sociedade industrial como "sistema em mudança contínua" a uma sociedade cujas configurações são "relativamente estáveis"; a incorporação do conflito como "processo social básico que tende à institucionalização e determina a direção da mudança" a uma visão pejorativa do conflito. Outros autores apontados como estrutural-funcionalistas, dos quais o autor destaca Amitai Etzioni, citados como exemplo, foram os responsáveis também por uma transição da noção processual linear e ordenada da composição organizacional para outra visão menos retilínea da individualidade e dos conflitos entre o sistema e seus componentes, noções estas que irão criar condições para as teorias de sistemas (Motta, 2001, p.15)

Em se tratando de teoria das organizações é muito interessante a esta dissertação, notadamente em assuntos que serão tratados posteriormente tal qual conceitos de gestão democrática e autonomia, a introdução da ideia de participacionismo de orientação socialdemocrata, entendida neste trabalho como possibilidade de construção de caminhos para organizações sociais não autoritárias, visando ao ideal aqui defendido por efetivamente democrático, o de autogestão. Uma abordagem bastante ampla do tema feita por Motta et al (1987) e resumida pelo mesmo, em linhas gerais de pensamento, conforme segue:

a) há, em primeiro lugar, uma linha burocrática ou tecnoburocrática, que salienta os aspectos eficientistas na participação. A participação é vista como instrumental para a eficiência burocrática;

b) há, em segundo lugar, uma linha fundamentada na doutrina social da Igreja Católica, que sublinha os aspectos da participação relacionados à justiça social;

c) há, em terceiro lugar, uma linha de orientação social-democrata, gradualista, que salienta o papel das formas de participação na evolução social;

d) há, em quarto lugar, uma linha de orientação marxista, que concentra sua 
análise nas formas de participação como formas de organização do proletariado; e) há, em quinto lugar, uma linha de orientação anarquista ou libertária, que descarta as formas de participação e se concentra na auto-gestão como modelo de organização social anti-autoritário;

f) há, finalmente, uma orientação autonomista, que percebe as experiências autônomas de comissões de fábrica como formas alternativas de organização que, já em si, representam um novo modelo de organização das relações sociais, bem como um novo tipo de subjetividade.

Motta (2001, p.39) considera que um dos principais pontos a serem destacados sobre a participação, a autogestão e as linhas de pensamento apresentadas neste trabalho, como possível nova orientação organizacional, está em sua relevância para 0 campo da administração da educação onde esta pode ser considerada, por si só, como um ato pedagógico. Uma proposta, ou sugestão, de Motta (2001, p.61) em relação à participação nas organizações está em introjetar os aspectos políticos a todos os indivíduos da organização, sem privá-los de iniciativas, responsabilidades e liberdades que os excluam de uma "apropriação do significado social e político de suas funções", que caracterizem um trabalho não alienado, sendo necessário, portanto, criar instituições permeadas por novas relações sociais que permitam essas apropriações, que permitam a participação de fato de todos os atores, com poder de decisão, em todos os processos organizacionais relevantes e estruturantes às coletividades.

O trabalho alienado é uma relação do trabalhador com o produto do trabalho como a um objeto estranho que o domina. Tal relação é similar com o mundo externo sensível. Também é uma relação do trabalho com o ato da produção, com a própria atividade, que não lhe pertence, "da atividade como sofrimento passivo, da força como impotência, da criação como emasculação", da atividade que se torna fim, não meio de vida. Por conseguinte, aliena a natureza do homem, o homem de si mesmo, seu papel ativo e sua atividade fundamental, e consequentemente do próprio corpo físico e suas características externas, da sua vida intelectual, da sua vida humana (Marx, 2002, p.114).

Para Tragtenberg (1990, p.16), a criação de "canais de participação real" para professores, alunos e funcionários do meio universitário, mas também do ambiente escolar público, tomado este como lugar com potencial de fato educativo por não estar necessariamente ligado à ideia de mercado, teria, na autogestão pedagógica, o mérito de devolver-lhes o "sentido de existência" fundado em motivações participativas ao invés de aspirações estritamente técnicas para, desse modo, superar a "delinquência acadêmica" caracterizada por "estruturas de ensino onde os meios (técnicas) se tornam fins", deixando de lado os anseios formativos ao sujeito histórico de criação, reprodução e 
apropriação do conhecimento em detrimento do "controle burocrático de sua produção". Reconhece que, ainda que a participação não seja um "remédio mágico" à esses males, a simples presença de outros suportadores, como alunos e pais, não ligados somente à burocracia escolar é fato de moralização em colegiados.

As relações de poder organizacional também começam a mudar em conjunto com a Industrialização das economias. Conforme Tragtenberg (1992), nos precursores das teorias de administração, Saint Simon especialmente, aparecem teses de transferência de poder administrativo da burocracia estatal para outras burocracias tidas como positivamente mais capazes, no sentido de positivismo científico, as quais eram representadas pelo sucesso e desempenho da classe industrial, daí a necessidade de sintonização com esta de outros interesses sociais, como a educação, a religião, as artes etc. Levando em conta, obviamente, o contexto dessas concepções. Contudo, essa configuração alterava os detentores do poder, mas não a forma pela qual este se dava, ou as relações pelas quais se fazia, visto que o controle era ainda a melhor maneira vislumbrada de exercê-lo. Um dos teóricos que vai mudar isso será Elton Mayo, que acreditava que a cooperação dos operários residia na aceitação espontânea das diretrizes da administração, ou seja, no convencimento dos indivíduos sobre condutas de trabalho vindas de seus superiores hierárquicos, substituindo o papel da contenção direta pela manipulação. A grande falha desta lógica, adotando uma posição, é sua incompatibilidade a interesses estruturalmente divergentes nas organizações (como os interesses salariais da classe operária em relação à classe dirigente, por exemplo) além da escamoteação de situações de conflito. Seria essa mesma lógica que acompanharia a Escola EstruturalFuncionalista em sua incorporação dos conflitos sociais como eventos a serem utilizados, ou "manejados construtivamente", a favor da administração ao invés de refutados por ela. Assim, a Escola das Relações Humanas era "behaviorista", fundada em princípios de estímulo e motivação da psicologia comportamental, a qual buscava "adaptar o indivíduo ao meio sem transformar o meio". Nesse quesito os estudos comportamentais eram submissos à institucionalidade, pois não ultrapassavam seus limites (Id. Ibid.).

Percebe-se nitidamente em Maximiano (2004b, p.268) a força do behaviorismo no campo da administração, no qual o estudo da motivação tenta explicar fatores ligados ao desempenho dos indivíduos em situações de trabalho, este ligado diretamente ao desempenho organizacional. $\mathrm{O}$ entendimento de resultado positivo neste caso pode estar no conjunto entre benefícios individuais, nos grupos de participação, no próprio indivíduo ou em toda a corporação. Assim, para que a motivação ocorra, faz-se necessária uma 
interação de motivos complexos, tanto aqueles internos aos indivíduos: a satisfação de necessidades, explicadas principalmente pela hierarquia de Abraham Maslow como fisiológicas, de segurança, sociais, de estima e de auto-realização, respectivamente, entre outras satisfações, como de aptidões ou de valores; quanto aqueles externos aos indivíduos, como estímulos ou incentivos do ambiente, procurando evitar a frustração, vista como resultado do não-atendimento de necessidades. O que fica evidente, lembrando Tragtenberg (1992) e Motta (2001), é que mesmo as contradições e divergências mais simples existentes entre organização e trabalhador não são abordadas nessas teorias de administração, vide também Dessler (2005), e essa relação pautada no desempenho, e não em questões organizacionais estruturais configura, na verdade, uma maneira de manipular o conflito na medida em que reforça o comportamento de desempenho individual direcionando-o à organização, substituindo o repertório de atitudes dos trabalhadores para algo positivo, muito mais em termos de rendimento corporativo do que de realizações pessoais, sociais, culturais etc.

Compartilhando a postura de Motta (2001), não se deveria criar ou estimular uma cultura organizacional que sirva apenas aos propósitos da organização, que direciona os interesses do trabalhador em prol dos objetivos organizacionais (como se fossem questões convergentes) ao invés de negociá-los. Uma cultura assim só faz se autoalimentar, visando a manutenção dos interesses das altas cúpulas, conforme dito anteriormente, e não a busca pela elaboração de uma cultura organizacional voltada para o livre desenvolvimento humano. Por isso também não é o caso de entender as organizações como "conjunto de elementos organicamente relacionados numa determinada configuração", como pregam as teorias de sistemas, de maneira que o todo se revela maior que a soma das partes, onde o sistema é tido como em contínua mudança em busca de adaptações que garantam sua sobrevivência, conforme pregam as teorias dos sistemas, pois essa alegada "sinergia" precisa ser entendida em suas finalidades, ou seja, a quem é realmente benéfica, assim como para a mutabilidade faz-se necessária a compreensão daquilo que não mudou e como isso afeta os diversos atores das organizações, ao invés do conjunto supostamente "uníssono". Em outras palavras, a falsidade das teorias de sistemas reside na constatação de que, por um lado, modificaram-se as formas de poder nas organizações ao longo do tempo, mas as relações de poder não mudaram, visto que ainda existem mandantes, compostos por minorias, e mandados, compostos pelas maiorias. Se as estruturas organizacionais capitalistas sofreram transformações, não mudaram seus objetivos de lucratividade e 
assim por diante. A intenção última delas, que não tem nada de "neutralidade científica," é a "integração dos dominados numa sociedade burocrática de consumo dirigida de forma a servir a uma camada social que aspira a se tornar classe dirigente: a tecnoburocracia", (Id. Ibid. p.85). Vale explicar que, para o autor, o que diferencia o burocrata do tecnoburocrata é basicamente o canal pelo qual se legitima seu poder. O primeiro é uma autoridade primordialmente formal, que depende da sua posição somente, enquanto o segundo é uma autoridade fundamentalmente profissional, ou seja, que depende de suas competências técnicas, profissionais.

Gramsci (1984) destaca duas formas de poder relacionadas a duas superestruturas: a coerção, ou domínio direto, que diz respeito à sociedade política, ou o Estado no sentido estrito, que se vale de mecanismos de coerção estatal para exercer "legalmente" seu domínio sobre grupos sociais discordantes, entre outras funções obviamente, mas cujas características principais são disciplinadoras, regimentadoras, reguladoras e que, por meio da força, não deixam aos grupos aos quais elas se se aplicam outra alternativa senão a "submissão a seus propósitos". Contudo, o consentimento às medidas disciplinantes só se realiza na presença de instrumentos coercitivos, em que, retirando-se estes, aqueles cessam de ocorrer e; a persuasão - que diz respeito à sociedade civil e aos organismos privados - caracterizada pelo "consenso espontâneo", obtido pelos mecanismos persuasórios inerentes aos meios de comunicação de massa, ao ensino, às associações culturais e científicas em geral, às igrejas, aos sindicatos, aos partidos políticos, enfim, a todos os organismos tidos como "privados". De qualquer forma, esse consenso se fundará na presença de argumentos favoráveis ao consentimento ou na ausência de argumentos contrários, ou em ambas as coisas, mas não em elementos de força direta. Uma grande diferença das duas está no "agente fiscalizador", ou seja, naquele que controla a execução, ou afirmação do poder. A coerção requer um sujeito (individual ou coletivo) externo de fiscalização, enquanto a persuasão incute no próprio sujeito receptor a relação de poder, prescindindo da presença permanente dos elementos persuasores, o que reforça a argumentação sobre as mudanças na forma de poder, mas não nas relações de poder, das organizações.

Não é o interesse aqui aprofundar discussões acerca do exercício do poder, mas, como aponta Paro (2008, p.40-41), vale o esforço de enriquecer o entendimento pretendido nesse sentido quando se faz um discernimento um pouco mais detalhado que o do parágrafo anterior acerca das maneiras pelas quais o poder, entre sujeitos individuais ou coletivos, é exercido. O autor separa três maneiras de praticar o poder: 
1. A coerção, onde "...há claramente um conflito de interesses entre quem detém o poder e quem é objeto dele", assim o poder pode se exercer mediante coação, ameaça de punição ou constrangimento e também por aliciamento.

2. A manipulação, em que "...a conflituosidade encontra-se presente, mas de forma potencial. Mesmo sem o uso da coação, aquele que exerce o poder provoca o comportamento do outro, ocultando ou camuflando seu verdadeiro interesse."

3. A persuasão, que "...supõe a completa ausência de conflito na relação de poder". Sendo que "...esse tipo de relação de poder só é possível se há o autêntico diálogo" entre as partes, o que gera como resultado, segundo o autor, que "...as subjetividades de ambos não ficam diminuídas, mas até reforçadas".

Fruto dos esforços de manipulação do capitalismo industrial, os ideais do progresso e do desenvolvimento das sociedades passam a ser confundidos com avanços tecnológicos, que se apresentam como maneira inexorável de se chegar ao bem-estar da humanidade (Motta, 2001). Na realidade, praticamente toda forma de tecnologia que permitiu a edificação da sociedade industrial está a serviço de formas específicas de dominação econômica e política, sendo esse o motivo pelo qual a construção de uma nova sociedade, que vise à democracia, deve passar, segundo Motta (2001, p.66), pelo "desenvolvimento de tecnologias alternativas a partir da auto-organização social", capazes de submeter a burocracia aos interesses gerais, ou de romper com ela. Lembrando que a Burocracia é, para Tragtenberg (1992), mais que uma mera forma de organização, é antes uma estrutura centralizadora de poder. Mais adiante, Motta (2001, p.98) complementa o raciocínio dizendo que o conhecimento técnico elevado à condição de caminho para a salvação, em que pesam como critério máximo de qualidade o desempenho utilitarista, objetivo e autocentrado de suas ações, causa o descolamento do papel das organizações para fora da estrutura social e desconsidera outras possíveis funções, impactos e determinações delas em seus ambientes.

Motta (2001, p.113) conclui, sobre a teoria das organizações que, enquanto ideologia do poder, ela "não apenas oculta o próprio poder e as contradições que lhe são inerentes, mas também é a forma pela qual a tecnoburocracia vê a organização, base última de seu poder" e que, em última instância, para eliminar seu falso pragmatismo e seus inúteis esforços de incluir aspectos substantivos em suas análises, deveria ser a ideologia dos participantes e não a dos seus senhores. 
Adiante, veja-se uma abordagem de perspectiva crítica sobre a gestão pública nacional, pretendendo permitir melhor visualização de uma conjuntura brasileira nesse tema que possa embasar as análises aqui almejadas.

\subsection{Gestão Pública - ênfase Brasil}

Uma versão relativamente otimista e bastante disseminada da história da gestão pública brasileira é a de Bresser Pereira (2001), que disserta sobre transições que levaram o Brasil, no plano político, de um Estado "oligárquico" e "autoritário", para um Estado "democrático", em que, apesar da continuidade dos traços elitistas, surgem sociedade civil e opinião pública com representatividade e importância crescentes. No plano administrativo, o autor alega a transição do Estado patrimonial, rústico, de economia agrícola e mercantil, seguido de um Estado burocrático, marcado pela regulamentação, para o atual Estado Gerencial, que age como um orquestrador atuante das esferas públicas. No plano social, a mudança se mostra na passagem da Sociedade Senhorial escravista que passa para uma Sociedade Capitalista-Industrial de classes, a uma Sociedade Pós-Industrial marcada pela substituição das classes por camadas ou estratos sociais cujo poder e renda derivam do controle do conhecimento técnico e organizacional. Segundo o autor, o primeiro momento da administração pública brasileira, datado a partir da colonização até o início do século $X X$, foi marcado por oligarquias autoritárias que, em sua gestão simplista, informal e pouco racional, confundiam o patrimônio público com o privado - numa sociedade cujo modo de produção escravista era majoritariamente agrícola-latifundiário - e tinha suas raízes nos moldes da colonização exploratória portuguesa. O segundo período, chamado de autoritárioburocrático, ocorreu durante o primeiro governo Vargas e, em boa medida, surgiu na tentativa de superar e combater as estruturas administrativas herdadas, substituindo-as por uma visão burocrática, principalmente no sentido de racionalização, formalização e profissionalização da gestão pública, que atendesse às novas perspectivas políticas, econômicas e sociais do cenário mundial ocidental. A centralização do poder da União sobre os estados federados e a criação do Departamento Administrativo do Setor Público (DASP) - órgão voltado exclusivamente para a formulação e execução da administração pública - são exemplos de esforços e medidas em ocasião. O termo autoritário se aplica à forma como foram implementadas essas mudanças, visto que não respondiam às reais necessidades da sociedade e foram conduzidas praticamente sem sua participação, 
envolvendo ainda muitas concessões às heranças patrimonialistas. Os anos seguintes serão de aprofundamento e enrijecimento da burocracia e perda da eficiência desta. Os destaques vão para a reforma desenvolvimentista iniciada em 1964 com os militares, baseada no Decreto-Lei 200, que visava à desburocratização e antecipava, em parte, a reforma gerencial, tratando da separação entre administração direta e indireta, a qual diminuía a concentração do poder permitindo maior autonomia aos componentes da administração indireta, como fundações de direito privado, empresas públicas e de economia mista etc. Porém, o período militar teve alguns graves efeitos contrários aos planejados no início do regime sobre os ideais de ordem e progresso - os quais primavam por controle estatal rigoroso sobre a economia e a sociedade e forte crescimento industrial - como o aumento e a disfunção administrativa do Estado, que culminaram, entre outros fatores, nas crises fiscal e política do final do regime militar.

Desse contexto, diz Bresser, surgem as necessidades de redução de custos e melhorias na qualidade dos serviços públicos ofertados à população. Mas vela lembrar aqui que na data em questão essas alterações estavam sob a égide da Constituição de 1988, portanto destaque-se que as mudanças no setor público não foram meramente administrativas e sim de todas as esferas, notadamente a política, além de terem seu início anos antes da chamada Reforma Gerencial. Com a Reforma Gerencial de 1995 (capitaneada pelo mesmo, Bresser Pereira, durante o governo de Fernando Henrique Cardoso), parte-se em busca de uma reestruturação do Estado, a alterar bruscamente o papel deste em suas atribuições e características, baseada nos princípios de "democracia e eficiência". Isso se traduzia, para o autor, em: gerar critérios de desempenho que norteassem a qualidade e efetividade do atendimento público ao cidadão e; limitar as ações do Estado àquelas que fossem tidas como exclusivas deste - em núcleos estratégicos e agências executivas ou reguladoras - assim como no financiamento a organizações cujos propósitos fossem de finalidade exclusivamente pública (como a saúde e a educação), deixando as demais atividades, não-exclusivas do Estado, ao setor privado (produção de bens e serviços para o mercado, por exemplo) (Id. Ibid.).

Neste trabalho, a versão acima colocada da administração pública nacional é posta em cheque, em sua gênese, sua análise de conjunturas e suas conclusões e implicações reais (já que foi posta em prática a "Reforma Gerencial"), conforme aponta Souza (2004, p.80), que faz críticas a diversos aspectos dessas concepções que incluem o paradigma do subdesenvolvimento brasileiro em noções complementares de familismo, personalismo e patrimonialismo para fundamentar a ideia de uma sociedade pré-moderna em que as 
mazelas sociais seriam fruto das expansões dessas noções a todas as suas esferas. 0 pressuposto implícito dessa estratégia analítica ocorre por se manterem as premissas do culturalismo essencialista, onde a cultura é percebida como entidade homogênea, totalizante e auto-referida, e da noção "etapista" da sociologia tradicional, em que se assume que apenas a reprodução do processo contingente da modernização ocidental garante a passagem para a modernização das relações políticas, econômicas e culturais. Assim, a naturalização da desigualdade social e a produção de "subcidadãos" como um fenômeno de massa no Brasil podem ser mais adequadamente vistas não a partir de supostas heranças pré-modernas, mas como resultantes desses processos de modernização importados e implementados em grandes proporções desde o início do século XIX, para os quais se deve analisar a desigualdade, a complexidade e a dinâmica que Ihes são peculiares.

A compreensão sobre gestão pública brasileira adotada neste trabalho acompanha as versões complementares de Alberto Guerreiro Ramos e Ana Paula Paes de Paula. De acordo com Ramos (1983), podem-se distinguir três períodos na evolução da administração federal no Brasil: o primeiro deles, desde a Independência até 1930; o segundo, durante o primeiro governo Vargas, de 1930 a 1945 e; o terceiro, de 1945 até os dias correntes (levando em conta a época em que foi publicado o livro, 1983). O primeiro período, marcado por dois regimes, o monárquico e o republicano, apesar de sua longa extensão de cem anos, "teve significado sociológico bastante estável", em que a administração pública, além de suas funções comuns, atendeu principalmente à necessidade de absorver o excedente de mão-de-obra ao qual o principiante sistema produtivo do país não dava conta de ocupar, assegurando posições e funções a razoáveis contingentes de pessoas e contribuindo, embora precariamente, para a formação de uma classe média não desprezível à nossa evolução política, econômica e cultural. O caráter rudimentar da sociedade se refletiu na administração pública que, em tais condições, tinha em suas atividades exigências muito singelas. Bastava ao servidor, basicamente, o conhecimento das leis, regulamentos e praxes, predominando no seu trabalho o espírito jurídico-legal. A década de 30 denota "a transformação de envergadura nas condições objetivas do país". O contexto mundial, pós-crise de 1929, determina mudanças econômicas profundas. De positivo, a economia nacional passa a substituir grande parte dos suprimentos provenientes do exterior pelo setor interno, fator decisivo à formação de um mercado interno praticamente inexistente até então. Três ministérios foram criados, do Trabalho, Indústria e Comércio, da Educação e Saúde, e da Aeronáutica, mas a 
complexidade da administração pública podia ser percebida pelos inúmeros serviços, notadamente autarquias e sociedades de economia mista que surgiram dos novos encargos impostos ao Estado. Se fosse para evidenciar algo que caracterizasse esse segundo período, comenta o autor, seria o imperativo da eficiência, na medida em que se configuraram significativas padronizações racionais e centralizadoras da utilização dos recursos públicos, podendo-se afirmar que o período foi marcado por uma "verdadeira revolução administrativa no Brasil, tal o porte das modificações de estrutura e de funcionamento que se verificaram em nosso serviço público federal", Ramos (1983, p.346). Contudo, prossegue o autor, a partir de 1945, reforça-se a percepção do crescente descompasso entre a administração pública e a nova realidade nacional, tornando-se notório que esse anacronismo afeta o país em larga escala. A integração dos mercados e a transferência do centro dinâmico do exterior para o interior do país, os avanços tecnológicos em transportes, meios de comunicação e outros, a adiantada graduação de divisão social do trabalho, entre tantas outras questões que criaram novas demandas entre os recebedores dos serviços públicos, impõem a revisão dos critérios de estruturação e funcionamento do sistema administrativo, tornando-se logicamente necessária uma reforma radical, que não considere a questão de maneira fragmentária, mas global e dinâmica. Ainda que algumas providências demonstrem que nossa administração federal já entrou definitivamente na fase de planificação - isto é, compreendendo-se que todo o sistema administrativo anterior tinha cumprido seu papel histórico e se tornara obsoleto - não se pode pensar que os critérios dominantes nas fases precedentes, o jurídico e o da eficiência, tenham perdido vigência.

Enquanto a obra de Guerreiro Ramos supracitada traz um apurado levantamento sociológico crítico da administração pública no Brasil, Paes de Paula (2005), em semelhante perspectiva, faz minucioso estudo da gestão pública mais recente, aprofundando as críticas aos modelos administrativos anteriores e principalmente à corrente denominada "gerencialista". Diz a autora que a administração, historicamente permeada pela racionalidade instrumental, em que se enfatizam as soluções técnicas em detrimento dos fatores sociopolíticos, resulta num descompasso entre três dimensões fundamentais para a elaboração de uma gestão pública democrática, sendo elas: $\underline{\text { a }}$ dimensão econômico-financeira, que envolve questões de natureza fiscal, tributária e monetária; a dimensão institucional-administrativa, que abrange quesitos organizacionais de articulação dos órgãos estatais componentes, de planejamento, direção e controle das ações governamentais e da profissionalização dos servidores públicos para 
desenvolverem suas funções e; a dimensão sociopolítica, que compreende problemas das relações entre Estado e sociedade, de direitos e participação dos cidadãos na gestão pública.

É pautada nessa última dimensão, majoritariamente, que a autora desenrola críticas à vertente gerencial, proposta no Brasil por Bresser Pereira durante o Governo FHC, como já dito anteriormente. Essa vertente não foi bem-sucedida, afirma a autora, por focar a nova administração pública como modelo de gestão empresarial, deixando muito a desejar naquilo que se refere à democratização do Estado, em que se modificaram os contornos administrativos, mas permaneceram as características centralizadoras e autoritárias. Paes de Paula (2005, p.125) salienta que "a reforma gerencial brasileira foi um desdobramento do ajuste estrutural da economia, que teve início com a adesão do governo Collor às recomendações do Consenso de Washington para a crise latino-americana". Num primeiro momento, aqui, o reformismo seguiu à risca as teorias neoliberais - as quais podem ser resumidas numa releitura adaptada para o cenário mais recente, atribuída principalmente à política britânica Margaret Thatcher, do liberalismo clássico de Adam Smith e seus ideais sobre a atuação mínima do Estado, para o qual deveriam restar apenas funções de regulamentação e fiscalização, primando pela liberdade máxima e autorregulação dos mercados como a melhor forma de funcionamento harmônico das economias e, por suposto, de todas as outras questões essenciais ao desenvolvimento das sociedades no mundo - mas após algumas experiências de ajuste estrutural e crescentes críticas que apontavam para a tendência de desmonte do Estado e das políticas sociais, as alianças sociais-liberais brasileiras migraram para a esfera da "terceira via", famosa por meio do seu mais ilustre autor, Anthony Giddens.

Paes de Paula (2005, p.66) reforça as contradições incipientes à essa nova proposta lembrando que, contudo, essa terceira via trazia em seu bojo um paradoxo problemático: no campo do discurso fazia oposição ao neoconservadorismo e seu radicalismo mercadológico, mas, na prática, mantinha a visão liberal de estruturação da nova administração pública, apoiada num princípio de igualdade de oportunidades (muito afastado das realidades sociais), direcionada primordialmente a uma hipotética eficiência técnica, ainda sem compromisso com a dimensão sociopolítica e democrática. Por fim, Paes de Paula (2005, p.178) compara a administração pública gerencial da década de 90 no Brasil a uma sugestão efetivamente inovadora, chamada de "administração pública societal", por ter na dimensão sociopolítica seu eixo formador. A reforma gerencial, ao 
enfatizar mais as questões estruturais da gestão pela divisão das atividades exclusivas e não-exclusivas do Estado, deu maior clareza à organização do aparelho estatal mas, concomitantemente, também o diminuiu e fragilizou em determinadas funções vitais de prestação de serviços graças a um modelo de privatizações de origem estrangeira, portanto elaborado para um outro contexto distante do nosso, sendo assim pouco adequado às nossas condições reais, somado ao agravante do modo apressado da sua aplicação. Ainda, os apelos sobre o desempenho e a qualidade fortemente baseados nas teorias administrativas do setor privado, mesmo que tenham aprimorado a eficiência do setor público, especialmente no campo econômico-financeiro, praticamente não se refletiram em benefícios com alcance universalizante, nem estimularam a elaboração de instituições políticas mais abertas à participação social, pelo contrário, centralizaram os processos decisórios nos tecnoburocratas. Por outro lado, a proposta societal, que não fornece alternativas sistemáticas à organização e gestão coerentes com seu projeto político, nem conseguiu ainda desenvolver uma estratégia que articule as três dimensões citadas, procura construir um projeto de desenvolvimento que atenda aos interesses nacionais, por meio de instituições e políticas públicas mais abertas à participação social e voltadas para necessidades e interesses dos cidadãos, por conseguinte, menos representativas e mais participativas. Recordando-se dos discursos de Alberto Guerreiro Ramos, a autora diz que a resposta para a nova administração pública "deve ser essencialmente não-prescritiva e se orientar para o curso de ações e necessidades dos cidadãos em um dado momento, evitando os enfoques normativos e subordinando a teoria das organizações à teoria do desenvolvimento humano" (Paes de Paula, 2005, p.180).

\subsection{Gestão escolar democrática}

A respeito da democratização do ensino brasileiro, Mendonça (2000, p.80) lembra que o assunto não foi único e consensual ao longo do tempo, já que teve e tem, até hoje, significados distintos para muitas pessoas. Para alguns seu entendimento resume-se ainda à universalização do acesso à escola e foi principalmente essa questão da expansão de matrículas, especificamente no ensino básico, a ter sido perseguida e implementada no Brasil nas últimas décadas, tanto por força de mobilizações sociais acerca do tema, quanto por exigência constitucional a partir de 1988. O Estado, nesse 
período, foi capaz de promover grande expansão no acesso da população à escola pública brasileira ${ }^{1}$, mas esse crescimento não veio acompanhado de preocupação e cuidados, por parte dos governos, em relação à qualidade da educação, a qual é imprescindível à democratização da educação, no sentido de dirimir as diferenças de formação e de oportunidades dadas aos alunos advindas dessas distâncias qualitativas.

Ao se falar de qualidade em educação é vital que se faça aqui uma diferenciação: o conceito "tradicional" de qualidade de ensino a considera passível de medição por meio de testes que pontuem a quantidade de informações exibidas pelos alunos, lembra Paro (2007, p.20). Segundo ele, essa concepção não apenas predomina nas estatísticas utilizadas pelos organismos governamentais, propagando-se de maneira majoritariamente superficial e acrítica por toda a mídia, como acaba por embasar muitos estudos acadêmicos sobre políticas públicas em educação. Nesse sentido confunde-se a qualidade de ensino com as aprovações, ou notas obtidas pelos alunos, nas tradicionais disciplinas curriculares, como Português e Matemática, exaltando-se assim escores que representam a suposta "efetividade" da escola em transmitir uma maior quantidade desses conhecimentos específicos aos educandos. Essas informações curriculares não deixam de ser fundamentais, o que não se deve é tratar da qualidade de ensino, como um todo, pautando-se somente em termos quantitativos, pois assim não são levados em consideração os importantes fatores subjetivos da educação, como a assimilação de valores, gostos, posturas, crenças e aptidões, bem como aquilo que o autor considera ser um elemento mais relevante que buscar e auferir resultados: verificar e desenvolver os processos educativos.

A visão que baseia este trabalho sobre a qualidade em educação e, inserida nesse universo, a qualidade de educação escolar, como dizem Dourado, Santos e Oliveira (2010), é de um conceito amplo, complexo e historicamente constituído, portanto em constante edificação. Os autores tratam de algumas questões consideradas fundamentais desse conceito que se aplicam ao ambiente escolar, tal qual às condições objetivas e subjetivas para os aspectos pedagógicos, de avaliação e de administração escolar, que devem incluir um conjunto de qualidades como: a disposição de recursos não mínimos, mas suficientes para oferecer os insumos indispensáveis às múltiplas necessidades

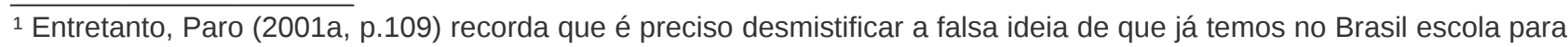
todos, ou quase todos, pois a quantidade "não pode existir no vazio sem referir-se a alguma qualidade", dada a situação precária de tantas escolas brasileiras que não satisfazem sequer as mínimas condições de convivência humana e os mais elementares critérios didático-pedagógicos
} 
escolares, boas condições de trabalho, de materiais, de infraestrutura, de gestão, entre outros, capazes de proporcionar e induzir as escolas à concretização de seus objetivos pedagógicos, à realização de uma função social inclusiva e transformadora, à construção de sujeitos engajados técnica, pedagógica e politicamente.

Embora existam na Constituição Federal mais recente e na Lei de Diretrizes e Bases da Educação Nacional referências e princípios da gestão democrática e da qualidade do ensino público, essas disposições legais esbarram tanto na insuficiência em descrever e definir com maior precisão mecanismos que garantam ações administrativas educacionais efetivamente mais democráticas, explica Mendonça (2000), assim como num Estado cujas história e estrutura são marcadas por características oligárquicas e patrimonialistas, burocráticas e tecnicistas e, mais recentemente, neoliberais, conforme as abordagens complementares de Ramos (1983) e Paes de Paula (2005). Características estas que tiveram seus diferentes momentos mais marcantes na administração pública brasileira, mas que podem ser percebidas com nitidez até os dias atuais e que demonstram formas de governo e gestão ainda muito distantes dos ideais republicanos e democráticos constitucionalmente previstos, principalmente no que se refere à descentralização do poder e à busca por igualdade social.

Entre os fatores essenciais à qualidade de ensino, conforme aponta Mendonça (2000, p.82), figura a gestão escolar democrática, que aparece pela necessidade de alteração das estruturas de poder na gestão dos sistemas de ensino público, incluindo, além das escolas, os departamentos, secretarias e outros órgãos educacionais, os quais não apenas são tutelados e regulamentados pelos sistemas políticos como trazem consigo boa parte das características históricas anteriormente citadas desse Estado, sendo a gestão democrática uma provável resposta ao insucesso da escola pública nacional em democratizar e fornecer um ensino de qualidade, em que pese uma administração escolar voltada para a transformação social em detrimento de uma administração escolar marcada pela racionalidade capitalista excludente.

Paro (2001a, p.10) desenvolve essa lógica explicando que as escolas públicas brasileiras, de maneira geral, são reprodutoras da injustiça social, já que recolocam as pessoas nos lugares reservados por relações econômicas, formando-as para um mercado de trabalho com pequenas chances de mobilidade social. Disto decorre que se é desejável uma escola transformadora que não alimente esse ciclo, é preciso transformar a própria escola e essa mudança passa pela necessidade de profundas alterações nos sistemas de autoridade e de distribuição de trabalho no interior da escola. O que se tem 
hoje é um sistema hierárquico que, em tese, concentra todo o poder nas mãos do diretor, porém gera uma contradição: o diretor supostamente possui direito e autonomia para comandar, mas, de fato, por sua condição de responsável último pelo cumprimento legal, acaba por exercer muito mais esta função que a de gestor escolar, em suas atribuições administrativas e pedagógicas. Esse estado de falta de autonomia do diretor é um reflexo da situação de pouca autonomia da própria escola e, somente à medida em que se conseguir a participação de todos os setores envolvidos com a escola (professores, alunos, pais, funcionários e comunidade), atribuindo-lhes poder de decisão sobre os objetivos e o funcionamento desta, é que haverá condições para pressionar os escalões superiores, sendo esta a única forma crível a conquistar recursos satisfatórios e autonomia para a escola. Por essas razões o anseio de um papel transformador passa pela democratização da gestão escolar.

Também acerca da concepção de gestão escolar democrática do ensino público, Mendonça (2000, p.402) separa cinco categorias essenciais distintas, mas intimamente relacionadas, expressando-as do seguinte modo:

1) A participação dos diferentes segmentos da comunidade escolar e, mesmo da comunidade externa, considerando-a o pano de fundo de todos os fatores que possam propiciar e materializar os processos da gestão democrática na medida em que os interesses da população, portanto públicos, sobreponham-se a interesses particularistas, sendo este um tema em que teoria e legislação já avançaram bastante, embora a prática ainda demonstre a prevalência de diretores, professores e funcionários em relação aos pais e outros integrantes nos foros de participação;

2) A maneira como cada sistema realiza o provimento dos cargos de diretor ${ }^{2}$, sendo mais tradicional o cargo de confiança por meio de nomeação, o qual é altamente criticável por abrir caminhos ao clientelismo e apadrinhamento político, além de sua volátil vinculação aos ciclos políticos. A adoção de concurso público como forma de provimento do cargo é um mecanismo alternativo que representa avanços à indicação, mas a qualificação, com critérios de impessoalidade, pré-requisitos de diplomação e medição por prova, não garante a competência do profissional, aproximando-o mais da figura do funcionário burocrático. A eleição de diretores pela comunidade escolar (sendo apenas os professores elegíveis ao cargo) é o

$\overline{2}$ Sobre o provimento de cargo de diretores recomenda-se também Dourado (2006). 
processo que melhor materializa a luta contra o autoritarismo na administração da educação, de acordo com o autor. Há, por fim, o sistema misto de provimento, com pré-seleção de candidatos por meio de provas de conhecimento seguida de alguma forma participativa de escolha dos classificados;

3) A implantação e o funcionamento dos colegiados, os quais, apesar das dificuldades para se formarem e funcionarem relativas ao relacionamento entre os diferentes segmentos representantes da comunidade escolar, em especial com o diretor, são ainda um mecanismo essencial à promoção do despojamento da dominação de uma só pessoa, o que remete à quarta categoria;

4) A descentralização pedagógica, administrativa e financeira, a qual, defende Mendonça (2000, p.414) não deve se restringir aos aspectos formais da gestão educacional, pois estes não se estendem às questões de processos participativos ou a alterações nas estruturas de poder dos sistemas de ensino, visto que as burocracias centrais e intermediárias expandem-se cada vez mais, justificando-se por meio da criação numerosa de projetos e exigências formais e assim prejudicando a autonomia escolar. As descentralizações também não devem significar completa desvinculação das responsabilidades do Estado com a escola e vice-versa, basta olhar para o exemplo da descentralização financeira que, devido à escassez de recursos, torna-se administração da escassez, em que a escola é instada a superar por si mesma suas dificuldades materiais (ideia esta compartilhada por Paro (2001a)), funcionando como fator agravante de abandono e distanciamento do Estado por isentá-lo, em parte, desse ônus, e podendo ainda aumentar o fosso entre escolas de um mesmo sistema, visto que comunidades em melhor situação econômica naturalmente possibilitariam condições especiais às escolas de seus filhos, enquanto outras, em piores contextos, não conseguiriam o mesmo, aprofundando as desigualdades entre elas;

5) A autonomia escolar, na qual o projeto político pedagógico é apontado, quando sua elaboração é participativa, como uma das principais expressões coletivas da comunidade escolar na busca de sua identidade e, por conseguinte, da autonomia escolar, mas Mendonça (2000, p.417) completa o raciocínio constatando que

(...) não há registros de que as administrações centrais tenham realizado adaptações radicais no sentido de considerar a escola como centro e razão de ser da existência de sua burocracia. Ao contrário, o que se pode verificar pela análise das normas fixadas pelos sistemas de ensino em relação à autonomia escolar é que os documentos são muito parcimoniosos no estabelecimento de mecanismos 
concretos que caracterizem a faculdade de a escola governar-se por si própria, mas profusos em estabelecer limites que verdadeiramente barram sua autonomia.

Vieira et al. (2002) tentam deixar claro o obstáculo a ser ultrapassado pelos gestores da escola, formais e informais, em seus papéis de mediadores e decisores, assim como pelos outros profissionais e pessoas também envolvidos com a instituição, visto que o desafio da elaboração do projeto pedagógico está ligado ao anseio da comunidade de ver demonstrada pela escola uma proposta capaz de explicitar as intenções político pedagógicas que embasam suas práticas. Para tanto, o projeto pedagógico precisa partir do contexto real de cada escola, admitindo sua singularidade e especificidade dinâmica de construção enquanto instituição educativa.

Seguindo o tom sugestivo das citações anteriores, Vieira et al. (2002) levantam alguns desafios que a escola atual deve enfrentar em sua gestão. O primeiro desafio é achar um rumo de ações diante das novas e complexas tarefas que passam a ser exigidas da escola. O segundo está na maneira de encarar as relações da instituição de ensino com a comunidade em que está inserida. O terceiro aparece na dificuldade de construir laços culturais entre o ambiente local e o global. O quarto desafio será de promover o sucesso de todas as crianças. Já o quinto desafio reside na compreensão e aplicação das formas e necessidades de avaliar a escola numa perspectiva transformadora.

Para a concretude de um projeto de escola pública de qualidade, no caso da administração escolar, Paro (2007, p.27) insiste que seus objetos de estudo devem considerar tanto a realização dos fins educativos quanto as mediações necessárias para concretizá-los, ou atividades-meio, e não somente as atividades de direção, tendo em vista a finalidade democrática intrínseca ao empreendimento educacional - finalidade esta que não se reduz ao "consumidor que tem direitos", mas se caracteriza pela participação ativa dos cidadãos na vida pública tanto como "titulares de direitos" quanto como "criadores de novos direitos". Pode parecer óbvia a necessidade de adequação dos meios aos fins, diz Paro (2001a, p.108), mas no ensino público essa evidência é permanentemente ignorada, tanto pela insistente sonegação de recursos materiais e financeiros em quantidades minimamente razoáveis para fazer frente às atividades inerentes à escola, quanto pelo uso de processos administrativos que negam imperativamente o objetivo de relações humanas livres de dominação, essencial a qualquer esforço realmente educativo. Articulada a essa medida, prossegue o autor, é também vital dotar a unidade escolar de autonomia administrativa e financeira em relação 
ao Estado, não se tratando de abandono por parte deste ao seu dever de financiar o ensino, mas de descentralização efetiva de todos os recursos que podem ser geridos pela escola, exigindo desta a prestação de contas direta e disponibilizando mecanismos que permitam, aos usuários, a fiscalização sobre a aplicação dos recursos disponíveis. De acordo com Paro (2001a, p.111), não é questão de defender uma pureza para a escola que a deixaria fora da realidade humana, mas de entendê-la como um meio de transformação que não renuncie a seu papel histórico de contribuir para a superação, pelos sujeitos, da alienação ${ }^{3}$ e ausência de criticidade prevalentes no processo capitalista de produção. Constatando o conservadorismo da teoria e da prática da administração escolar vigente, Paro (2001b) traz alguns pressupostos básicos de uma administração escolar de fato comprometida com a transformação social. O primeiro deles diz respeito à especificidade da administração escolar, assumindo seu papel revolucionário na medida em que consiga levar os sujeitos ao direito de se apropriarem do saber historicamente acumulado pela humanidade, desenvolvendo consciência crítica da realidade em que se encontram. O segundo se relaciona às racionalidades internas e externas à escola, em que pesem as determinações sobre a sua função perante a sociedade e seus objetivos próprios, que não podem ser neutros, a-históricos, mas direcionados a essa função. O terceiro trata da participação coletiva, sem a qual suas atribuições e finalidades, aqui já discutidas, se tornariam educacionalmente inválidas. O quarto se refere à consideração das condições concretas para essas realizações, as quais incluiriam novos padrões de racionalização do trabalho e de coordenação dos esforços humanos coletivos, além de questões sobre os recursos suficientes, também anteriormente já levantadas.

Desse modo, podem ser aventadas algumas medidas aos inúmeros assuntos aqui problematizados, de acordo com Paro (2001a), Paro (2001b) e Paro (2007): há que se rever o papel do atual diretor da escola pública como responsável último e culpado primeiro das questões escolares, o qual se perde em meio à multiplicidade de tarefas burocráticas que pouco têm a ver com a busca por objetivos pedagógicos, transformandoo de "chefe" a colaborador que, embora tenha atribuições, compromissos e responsabilidades diante do Estado, não seja o único detentor da autoridade, a qual deve ser distribuída entre todos os membros da equipe escolar.

Pode-se pensar, sugere Paro (2001a, p.112-114), num "Conselho Diretivo" em que a direção seria exercida por um colegiado, onde o "Coordenador Geral", de cargo eletivo,

${ }^{3}$ Conforme o conceito marxista de alienação, que pode ser encontrado em Marx (2002). 
não teria o papel que hoje desempenha o diretor, mas seria mais voltado à integração dos vários setores e ao desempenho do pessoal, pois o dividiria com seus membros, que poderiam ser um "Coordenador Pedagógico", responsável por cuidar mais das atividadesfim da situação do ensino e de sua viabilização, um "Coordenador Comunitário", que cuidaria mais de perto de promover o envolvimento da comunidade e um "Coordenador Financeiro", a quem estariam subordinadas questões de aplicação de recursos e da parte escritural da escola, os quais seriam recrutados na própria unidade escolar entre os professores (providos por concurso público) e teriam mandatos temporários, eleitos por parte do pessoal escolar, alunos e pais. Paralelamente a esse "Conselho Diretivo" continuaria a existir o Conselho de Escola, de caráter consultivo e deliberativo, em composição semelhante à atual, mas com enriquecimento de suas funções, englobando também as finalidades legais das atuais Associações de Pais e Mestres, que seriam extintas. Outro ponto desejável numa "reestruturação administrativa das escolas públicas, visando a uma gestão escolar consistente, diz respeito aos Conselhos de Classe e de Série, procurando remover seus vícios de supervalorização de notas e conceitos e de não conseguir perceber a inadequação da escola para o ensino, jogando a culpa de sua incompetência sobre o aluno alegando falta de motivação e compromisso. Portanto é preciso admitir a irracionalidade da avaliação externa da escola por meio de testes semelhantes aos concursos vestibulares. "Por isso, em termos administrativos, a escola tem de ser avaliada em seu conjunto, levando em conta a avaliação como elemento imprescindível no processo de realização de objetivos".

Se faz sentido preocupar-se com a gestão das escolas, Paro (2001b, p.18) alerta que há que se considerar inicialmente o próprio conceito de administração, ou de gestão (tomados aqui como sinônimos), adotando assim uma concepção mais simples destas, como "utilização racional de recursos para a realização de determinados fins" lembrando que para a educação e o ensino esses fins devem vincular-se à função de transformação social - a fim de lhes atribuir um significado abrangente, menos associado às suas determinações históricas e sociais, em especial àquelas do modo de produção capitalista e de uma sociedade de classes. Sob essa ótica torna-se possível raciocinar os termos em que essa administração pode ser vislumbrada para que esteja voltada à mudança social e a propósitos não autoritários.

Após expor aqui algumas concepções acerca da qualidade de ensino e da gestão escolar democrática, nota-se ao menos um juízo de valor comum, dentre os autores, a esses conceitos: a perspectiva de transformação social. No campo teórico, a distinção 
crítica desses autores, ao enxergarem esse valor como possibilidade real, apesar do conjunto de estruturas objetivas e subjetivas capitalistas desfavoráveis, pode ser explicada por Saviani (2008, p.4), que parte do problema da marginalidade para classificar as outras teorias educacionais em dois grupos:

1) Teorias que pressupõem a educação como um mecanismo de inserção social, logo, de superação da marginalidade, porque veem esta como fator acidental da sociedade, uma distorção a ser corrigida. Nesse contexto a educação tem a função de reforçar os laços sociais, integrando e conformando os indivíduos ao corpo social e evitando sua desagregação. Desse ponto de vista a educação possui grande autonomia em face da sociedade, por ser muito mais determinante desta que o contrário. Assim sendo, por encararem a educação como independente e buscarem compreendê-la a partir dela mesma, desconsiderando seus condicionantes objetivos (a estrutura socioeconômica em que estão inseridos os fenômenos educativos), Saviani (2008, p.5) denomina este primeiro grupo de "teorias não-críticas";

2) Teorias que concebem a sociedade como sendo marcada pela divisão de classes, cujos interesses opostos as mantêm em conflito. A marginalidade, nesse cenário, é vista como parte inerente à estrutura social que ocorre por apropriação desproporcional, pelos grupos dominantes, dos frutos da produção social. Consequentemente, parcela dessa sociedade é relegada à marginalidade. Nessa situação, essas teorias entendem a educação como subordinada à estrutura socioeconômica geradora de marginalidade e, portanto, reprodutoras da marginalização e dominação. Por esse motivo são denominadas pelo autor como "teorias crítico-reprodutivistas".

De fato, pontua Saviani (2008, p.24), a escola na sociedade capitalista reproduz a exploração e a dominação, conservando um caráter segregador, de natureza seletiva, já que é determinada socialmente. Contudo, prossegue o autor, se não é possível descontextualizar a escola de seus condicionantes objetivos, também não é sensato pensá-la fatalmente aprisionada por essa estrutura socioeconômica. Desse modo, uma teoria crítica da educação que não seja reprodutivista só poderá ser construída a partir do interesse dos dominados.

Da inferência a respeito de uma teoria crítica da educação que não seja reprodutivista, surge uma questão proveniente da mesma encontrada em Saviani (2008, 
p.25), dotada de uma pequena modificação restritiva ao objeto de interesse (a escola), mas não de conteúdo (administração escolar), com o intuito de adequá-la ao tema central deste trabalho: é possível uma teoria que capte criticamente a gestão escolar como um instrumento capaz de contribuir para a superação do problema da marginalidade?

Tendo em conta a sugestão de Vitor Paro sobre a relevância de pensar o próprio conceito de administração quando se trata do ambiente escolar e que, conforme proposto por Demerval Saviani, essa elaboração teórica deve ser permeada pela criticidade nãoreprodutivista, segue-se agora para o aprofundamento na questão de uma teoria crítica em administração.

\subsection{Estudos Organizacionais Críticos nacionais}

O termo que dá título a este tópico está vinculado ao trabalho de Paes de Paula et al. (2010), assim como ao livro de Paes de Paula (2008), nos quais os Estudos Organizacionais Críticos (EOC) recebem atenção pelo pioneirismo, tradição nacional e base científica diferente dos trabalhos estrangeiros dessa natureza, categorizados como Critical Management Studies. Da leitura desses trabalhos foram selecionadas algumas características aqui consideradas mais relevantes. Destaca-se primeiramente a origem dos EOC, que está ligada ao nome de dois principais autores, sendo eles: Alberto Guerreiro Ramos e Maurício Tragtenberg, cujas obras evidenciam-se pela base epistemológica considerada como humanista radical, por seu alinhamento com a fenomenologia e o existencialismo, que inspiraram Ramos, com o marxismo heterodoxo e o anarquismo, peculiares a Tragtenberg, e com a competência dialógica no questionamento radical de pressupostos científicos da Escola de Frankfurt. Em segundo lugar, cabe aqui uma breve explanação de Paes de Paula (2008, p.111) sobre as significações que esse humanismo radical implica e que são compartilhadas por Ramos e Tragtenberg, sendo elas: a importância que atribuem ao sujeito, individual ou coletivo (classes), e à ação deste nas organizações, incorporando a criticidade e a desesperança de que os sujeitos possam se emancipar no contexto de corporações econômicas, mas sem descartar essa possibilidade de vida em outros formatos organizacionais, em que exemplos práticos de participacionismo e autogestão ${ }^{4}$ ajudam a vislumbrar um cenário compatível com a autonomia e autoconsciência ${ }^{5}$. Por fim, faz-se necessário suscitar o que é ser crítico para os EOC, o que foi feito por Davel e Alcadipani (2003, p.74), ao 
estabelecer três parâmetros fundamentais para apontar um estudo do campo da administração como sendo de natureza crítica, os quais serão aqui abordados somente nas dimensões que concernem ao tema deste trabalho, conforme segue:

1) A adoção de uma visão desnaturalizada da administração, que assume a organização como construção social e histórica, denunciando aspectos de dominação, exploração, controle e exclusão na teoria e na prática administrativa, em contraposição ao processo de naturalização utilizado pelas teorias administrativas tradicionais, que tratam os arranjos institucionais como eventos naturais alheios à escolhas ou relações de poder, separando as organizações de seus contextos históricos, de suas composições e origens conflituosas;

2) Intenção desvinculada da performance, onde a busca por desenvolvimento de conhecimentos visa à superação das pessoas em relação aos mecanismos que as oprimem, rompendo com a lógica instrumental da maximização de resultados (pela eficiência, efetividade e eficácia) e com a suposta neutralidade científica, que não deixa espaço para questionamentos quanto a seus meios e, principalmente, seus propósitos.

3) Intenção emancipatória, em que se enfatizam e promovem a autonomia e a responsabilidade dos indivíduos, entendendo-se por autonomia a capacidade dos sujeitos de desenvolverem julgamentos que não sejam impedidos ou subordinados à relações de poder e desigualdade ${ }^{6}$ e, por responsabilidade, a consciência de interdependência social, de compromisso coletivo.

Tomando por pressuposto que as teorias administrativas, em sua natureza, podem ser qualificadas como uma ciência social, vale adicionar aos critérios de criticidade acima mencionados algumas notas, de Ramos (1957, p.19), sobre defeitos, ou tendências, presentes em boa parte dos estudos acadêmicos das ciências sociais no Brasil7: o primeiro deles reside na simetria, encontrada na disposição desses estudiosos a adotar literalmente aquilo que se apresenta como mais avançado nos centros europeus e norteamericanos e no sincretismo, fruto da tentativa desses autores de conciliar aqui doutrinas

\footnotetext{
${ }^{4}$ As reflexões e exemplos históricos acerca do participacionismo e da autogestão neste trabalho referem-se aos livros de Prestes Motta et al. (1987) e Tragtenberg (2005).

5. Paes de Paula (2008, p.32-33) explica a autoconsciência por: "...um sujeito que embora esteja sendo constituído por configurações subjetivas das quais não pode se conscientizar, está ao mesmo tempo produzindo de forma consciente um conjunto de projetos, reflexões e representações que são fontes de significados e sentidos que influenciarão o próprio desenvolvimento de sua subjetividade"
} 
peculiares a outros países, portanto, de outras realidades; o segundo defeito consiste no dogmatismo da ampla assunção de argumentos de autoridade, em que as discussões e avaliações dos fatos esgotam-se na mera sobreposição de textos de autores prestigiados, o que leva ao; dedutivismo, pois, ao considerar a validade absoluta das obras estrangeiras, estas passam a ser ponto de partida para a explicação dos eventos de contexto nacional; disto decorre a alienação da ciência social brasileira, visto que esta não se origina de esforços inclinados a promover a autodeterminação da nossa sociedade; resulta dessas quatro características a inautenticidade, já que o estudioso brasileiro dessa área recebe e usa processos científicos pré-fabricados, não baseados em experiências cognitivas genuínas, porque não participa de sua gênese. O autor completa a ideia explanando a criticidade para estudos em ciências sociais em dois termos: serão críticos na medida em que forem autênticos e colaborem para a autoconsciência nacional, mas para tal tarefa devem ser precedidos pela autocrítica, a servir como instrumento para afastar equívocos e vícios de análise, o que também implica na disposição para o debate, no trabalho coletivo da construção dos pensamentos e o que os suceder.

Mais especificamente sobre a área da administração, Tragtenberg (2005) reforça essas posições críticas relacionando-as à falsa representação das determinações sociais reais geradas pela ideologia administrativa das grandes corporações, a qual desconsidera os conflitos de classes e mesmo a existência de classes com interesses opostos, ou, quando o faz, trata a questão como problema a ser solucionado em prol da corporação, pois esta é tida num plano superior de relevância na sociedade em detrimento dos indivíduos que a suportam. Nessa ideologia também as discussões relativas à relações de poder não são representadas a partir de seus fatores de existência, mas suscitadas dentro de um pressuposto de que existem por uma "ordem natural dos fatos" a ser pensada em termos de otimização, e não de transfiguração, escamoteando o sentido das mudanças teóricas e práticas em novas maneiras que dizem respeito somente às formas e não ao conteúdo dessas relações de poder. Tratenberg (2005, p.54) exemplifica o que isso significa, lembrando que "a linguagem tecnocrática emprega o termo inovação em lugar de mudança. Sucedem-se revoluções organizacionais que nada mudam, revoluções

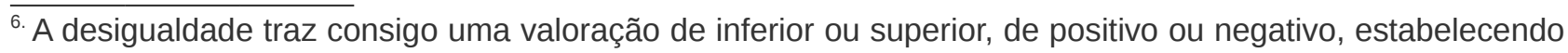
uma relação de poder, de hegemonia entre as partes, segundo Benevides (2010, p.11).

7. Considerando que essas observações não são definitivas, de acordo com Ramos (1957, p.26), e nem se aplicam à todas as ciências sociais, elas ainda podem ser facilmente verificadas, nos dias atuais, em alguns compêndios nacionais (de larga utilização) sobre teorias administrativas, como Chiavenato (2009) e Maximiano (2004).
} 
filosóficas que são revoluções filológicas". Disto decorre o equívoco envolto sob o nome racionalidade, visto que esse sistema carrega consigo o caráter de conservação de seus arranjos, de sua ordem.

Para a definição de outro conceito fundamental àquilo que se pretende neste trabalho, o da ação administrativa, faz-se necessária a distinção de ao menos duas compreensões sobre a racionalidade, a exemplo de Ramos (1981, p.23), quando escreve que "a razão é o conceito básico de qualquer ciência da sociedade e das organizações": na racionalidade funcional aprecia-se uma série sistemática de atos, independentemente do conteúdo que possam ter essas ações, para atingir um objetivo predeterminado; já a racionalidade substancial está ligada às ações intrinsecamente inteligentes, baseadas em conhecimentos lúcidos e autônomos das relações entre os fatos, que atestam a transcendência do ser humano, disserta Ramos (1983, p.39). O autor afirma que a razão da ação administrativa não é entendida como faculdade humana transcendental, mas restringe-se a eficácia e a operações produtivas que combinem recursos e meios de trabalho com vistas à concretização de objetivos contingentes, sendo que a inteligência da ação administrativa também requer outras referências sistemáticas, dentre elas a racionalidade substancial.

Ainda que pareça evidente a importância da relação entre as racionalidades e as ações administrativas, retomando Tragtenberg (1990, p.16), entende-se que o afastamento entre o pensamento e a ação revela uma das doenças que tipificam a delinquência acadêmica, que também pode ser compreendida como delinquência intelectual, já que a valorização de uma pessoa que se possa dizer culta passa pelas ideias que defende, pelo seu discurso, pelo seu comportamento, por sua existência, os quais, por si mesmos, já constituem atos políticos, formas de ação indistinguíveis da razão. O autor refere-se a essa desvinculação como delinquência, mais precisamente nos meios educativos, pelo engessamento burocrático causado pela inversão de valores pedagógicos em que as técnicas (meios) se tornam fins e as finalidades formativas são pormenorizadas, ou até abandonadas. A busca por conhecimento e sua propagação, sua incorporação pelos indivíduos, dão lugar à produção burocraticamente regimentada e parametrizada desse saber. Dadas essas circunstâncias, a maneira sugerida pelo autor para que as academias - o que pode ser compreendido como válido para todas as instituições de ensino - voltem a ter sentido em suas existências, está na autogestão pedagógica, a qual não transformaria questões políticas em problemas técnicos, nem trocaria vontades e decisões públicas por decisões de gabinete, sendo, possivelmente, 
capaz de romper com a inversão de valores e estruturas antes mencionadas. Ressalte-se que a proposição não é defendida como solução, mas possibilidade, considerando o que argumenta Lima (2001, p.112):

\begin{abstract}
Não basta alterar as regras formais para mudar as realidades escolares, e estas mudam, com frequência, mesmo quando as primeiras se mantêm inalteradas. Ou seja, não são apenas os modelos decretados que influenciam as práticas de gestão; estas práticas são influenciadas por múltiplos factores, objectivos, interesses, circunstâncias etc., que, por sua vez, não deixam de influenciar o entendimento e até a produção dos modelos decretados. E, assim, as diversas realidades escolares não se transformam automaticamente por simples mudança dos modelos decretados, como também a mera manutenção destes não assegurará necessariamente a cristalização de tais realidades.
\end{abstract}

Ao mesmo tempo que a sugerida autogestão no ensino não deve ser vista como solução definitiva dos problemas da gestão escolar, tendo em conta os trabalhos de Maurício Tragtenberg examinados, também não é correto associá-la à acepção de Lima (2001) de doutrina gestionária, ou modelo organizacional normativista e pragmático, cuja função é reproduzir, regulamentar e manter as estruturas organizacionais formais, mas pelo contrário, partindo de uma interpretação compartilhada também por Paes de Paula (2008), a autogestão defendida por Tragtenberg procura valorizar bases organizacionais democráticas, com relações horizontalizadas e cooperativistas, participação direta ${ }^{8}$ da sociedade civil e dos diversos atores da organização não somente nas decisões como nos processos de constituição e funcionamento da organização. E se fica a impressão de que a autogestão é utópica, maneira pela qual a ideia é frequentemente rotulada, Prestes Motta (2001, p.66) indica a incoerência dessa suposição atentando para o fato de que, todavia, "é bem menos comum a identificação do ideal do progresso técnico como via de construção de uma sociedade de bem-estar como utopia".

Tendo sido abordadas as questões e relações sobre a administração e a gestão escolar democrática, parte-se para o próximo capítulo visando a suscitar reflexões e posições para este trabalho acerca da qualidade do ensino nacional, assunto este essencial ao alcance do objetivo aqui proposto.

\footnotetext{
8. Diferentemente da co-gestão que é, na verdade, conforme Tragtenberg (2005), uma pseudo participação, já que escamoteia uma democratização parcial, portanto uma falsa democratização.
} 


\section{QUALIDADE EM EDUCAÇÃO ESCOLAR - ÊNFASE BRASIL}

\subsection{Concepções e contexto}

Sander (2008) procura tratar da educação brasileira a partir de espaços mais amplos, a estudando, interpretando e contextualizando ao fenômeno da globalização, no cenário da América Latina e do mundo, posto que a globalização possa representar hoje uma "crescente gravitação dos processos econômicos, políticos e culturais de caráter mundial sobre os processos de caráter regional, nacional e local". É crescente, portanto, a influência internacional, por meio de seus protagonistas, (organismos intergovernamentais de cooperação, agências de financiamento etc.) sobre a formulação das agendas sociais globais - e as agendas educacionais não são exceção a essa regra. Nas décadas de 50 e 60 as correntes desenvolvimentistas e o forte movimento internacional da economia do bem-estar social, com destaque para as teorias de capital humano, trouxeram a ideia de economia da educação, onde esta passou a ser considerada o motor das etapas do crescimento econômico e do atendimento aos planos de desenvolvimento. Outra corrente surgiu a fim de "evitar o assistencialismo reprodutivista e favorecer um genuíno processo de aprendizagem e construção coletiva", desde que fosse aceitável e relevante para os países e instituições participantes da OEA (Organização dos Estados Americanos). O principal compromisso dessa corrente, firmado numa reunião promovida pela UNESCO (Organização das Nações Unidas para a Educação, a Ciência e a Cultura) tinha por objetivo "erradicar o analfabetismo até o final do século XX, garantir dez anos de educação básica para todas as crianças em idade escolar e elevar a qualidade e eficiência da gestão dos sistemas educacionais", mas o projeto, que teve início em 1981, esbarrou nas dificuldades econômicas da chamada "década perdida" dos anos 80 e retrocedeu, dando lugar a "novas estratégias de gestão dos sistemas educacionais, baseadas na modernização institucional e na eficiência econômica". Porém, "não existem mais ilhas de prosperidade e segurança em nossa aldeia global" e dois desafios se apresentam ao Brasil e ao mundo, neles inclusa e indispensável a temática da educação, que serão de retomar os esforços de cooperação no campo das políticas públicas mundiais e agendas educacionais promotoras de cidadania planetária, sem perder de vista a fidelidade às realidades e aspirações locais (Id. Ibid., p. 159).

Maria Malta Campos (2000) entende que o tema "qualidade em educação" começa 
a aparecer com maior frequência nas pautas públicas brasileiras de discussões a partir da década de 80, período que coincide com a abertura política no país. O assunto, que já era tratado pela literatura educacional há mais tempo, passa a gerar preocupações, estas advindas dos graves problemas revelados pelos estudos no campo educacional assim como das demandas dos movimentos sociais, que foram capazes de surtir efeito nas políticas públicas na tentativa de responder a essas questões. As deficiências eram muito profundas, principalmente naquilo que dizia respeito ao acesso à educação escolar e à universalização do ensino, vistos num primeiro momento de elaboração constitucional como de responsabilidade pública, o que, entre outras medidas, implicava em aumento de investimentos públicos, mas afetados posteriormente por outras visões que tentavam responder à crise financeira do Estado à época, meados dos anos 90, com teses de enxugamento deste e de direcionamento de seus esforços para segmentos limitados da população, dividindo certas responsabilidades com o setor privado. Porém, o contorno dos debates ao redor da qualidade em educação escolar sofreu fortes mudanças, notadamente nos quesitos de quantidade e qualidade, a partir da década de 90, por meio da expansão das matrículas no período, evento este que transformou radicalmente o panorama do ensino escolar em suas características e composições humanas.

É difícil chegar a um consenso, mesmo entre especialistas, de uma noção do que seja qualidade de ensino, embora Oliveira e Araujo (2005) sugiram que se possa distinguir no Brasil três momentos desta: o primeiro deles priorizava a oferta do ensino, tida como insuficiente; o segundo trazia percepções mais direcionadas àquilo que se entendia como "disfunções no fluxo do ensino fundamental" e; o terceiro momento, que enfatiza uma "generalização de sistemas de avaliação baseados em testes padronizados". No primeiro momento evidencia-se o fosso criado entre as conquistas e garantias sociais estabelecidas na constituição de 1988, de cunho mais universalizante, em relação às necessidades de controle e restrição dos gastos públicos brasileiros do período. A problemática disso, para o ensino, foi que esse contexto favoreceu uma perspectiva de qualidade apoiada em ideias de eficiência e produtividade vindas de uma matriz claramente empresarial, que não compactuam com a democratização e a busca pela igualdade em amplos sentidos. Já para a questão das disfunções no fluxo do ensino, algumas medidas foram tomadas na tentativa de diminuir as diferenças entre matrículas do ensino básico para o fundamental, a fim de inibir a evasão escolar provocada pelas reprovações, que incluíam a progressão automática, os ciclos de ensino, programas de aceleração da aprendizagem, entre outros. O equívoco dessas medidas estava em 
orientações políticas de combate à reprovação que não se traduziram em novos arranjos organizativos, atingindo apenas parcialmente o quadro de imensas desigualdades da educação brasileira e cumprindo "de forma precária e pouco efetiva o seu ideal igualitário e emancipador". Por fim, o movimento mais recente tem sido da difusão de indicadores pautados em testes padronizados de larga escala (Exame Nacional do Ensino Médio ENEM e o Sistema Nacional de Avaliação da Educação Básica - SAEB, por exemplo), que aferem, em tese, os conhecimentos dos alunos conforme a etapa em que se encontram, mas que encontram bastante resistência entre os profissionais da educação, por motivos diversos.

Pedro Demo (2007, p.12) diz que sobre a dicotomia quantidade e qualidade em educação escolar não cabem argumentos de relevância ou importância comparativa. A quantidade é pré-condição e base para qualidade, é "corpo, tamanho, número e extensão", estrutura física e metafísica, indicando que qualquer pretensão qualitativa passa necessariamente pela quantidade. Como a qualidade aponta para uma dimensão de intensidade, ligada com a profundidade, a perfeição, a participação, a criação, está mais para o "ser" do que para o "ter". Paro (2001b, p.79) reforça essa argumentação, dizendo que antes da qualidade, a fim de que existam condições para as práticas educativas e administrativas escolares, é necessário um mínimo de condições, propiciadas pela disponibilidade de recursos, as quais, na atual situação do ensino, são sistematicamente negadas pelo Estado brasileiro. Já em relação ao significado da qualidade em educação, Demo (2007, p.13) propõe que o termo é mais propriamente aplicado à "ação humana", definida como o "toque humano" na realidade como tal, consequência natural da intensidade, que por sua vez só existe naquilo que tem a marca do homem, visto que se trata de "vivência, consciência, participação, cultura e arte". Assim sendo, apenas o que é histórico tem a capacidade de ser qualitativo, de saberfazer história, "ser" sujeito histórico ao invés de "massa de manobra, objeto de influência externa, sequela natural".

Freire (2002, p.110) complementa essa ideia de qualidade, dizendo ser imprescindível defendê-la como uma forma de intervenção no mundo, descartando sua neutralidade e afirmando o que se considera como imoralidade: os casos comuns de predominância dos interesses de mercado em detrimento daqueles radicalmente humanos vistos na educação.

Dourado e Oliveira (2009, p.204) enfatizam que "um primeiro aspecto a ser ressaltado é que qualidade é um conceito histórico, que se altera no tempo e no espaço". 
Portanto, o alcance desse conceito está intimamente vinculado ao contexto, às demandas e processos sociais de um dado período histórico. Milton Santos (2007) contribui para 0 entendimento dessa percepção quando acrescenta ao fator temporal da história humana também o elemento espacial, já que esses períodos distintos também subdividem-se em espaços humanos distintos, explicando o espaço do homem como "a acumulação desigual de tempos", ou melhor, a sobreposição não-estática, caótica e histórica da interferência humana.

A definição e a compreensão teórico-conceitual da qualidade da educação escolar, fenômeno complexo e abrangente, envolve múltiplas dimensões, não se limitando ao reconhecimento de variedades e quantidades mínimas de recursos necessários ao "desenvolvimento do processo de ensino-aprendizagem", complementam Dourado e Oliveira (2009, p.207). Ela deve incluir dimensões extra e intra escolares, considerando seus diferentes atores e sua dinâmica pedagógica, ou seja, os processos de ensino, os currículos escolares, as expectativas de aprendizado, entre outras questões externas aos muros dessas instituições de ensino. Devem também identificar as pretendidas condições objetivas e subjetivas de organização e gestão escolar e da avaliação dessa qualidade. Para tal, faz-se necessária a priorização da educação como política pública, o que implica em aumentar os recursos destinados a ela, regulamentar o regime de colaboração entre os entes federados, articular melhor as políticas e os programas da área, perseguir a gestão democrática dos sistemas e das escolas, consolidar programas de formação inicial e continuada juntamente com melhorias aos planos de carreira dos profissionais da área etc.

Qualidade de ensino não é questão de simples atualização de informações, visão implícita ao conceito "tradicional" de ensino, segundo Paro (2007). Em seu desenvolvimento, cada indivíduo reproduz, em sua biografia, o próprio desenvolvimento da espécie humana, vai-se fazendo histórico à medida que se apropria da cultura humana historicamente produzida, sendo a cultura entendida em sentido amplo e rigoroso, de produção em termos de valores, conhecimentos, objetos, crenças, tecnologia, hábitos, artes, ciência, filosofia etc. Nessa percepção, considerar a qualidade do ensino é levar em conta a que ponto se alcança essa formação, tendo presentes duas dimensões: a individual, que se refere à constituição da personalidade do educando enquanto ser que se autocria e transcende necessidades naturais em sua postura ética de modo a propiciar sua realização e bem-estar e; a social, que deriva da pluralidade do homem, não se tratando de educar apenas para o bem viver individual, mas para que o sujeito seja capaz 
de contribuir para o bem viver de todos - dado o momento da história em que são criados e sustentados valores sobre as carências e possibilidades de convívio livre e pacífico entre os vários sujeitos (individuais e coletivos), ou seja, democrático - pode-se dizer que a dimensão social do ensino deve referir-se obrigatoriamente à formação para a democracia. "Educar-se, portanto, é realizar-se como indivíduo componente de determinada sociedade" (Id. Ibid., p.110).

Parece fundamental deixar claro algumas restrições em se tratando de universo escolar, donde não se pode ignorar a intimidade entre as instituições formais de ensino com a educação, nem se pode atribuir somente a elas o peso desta, conforme afirma Ghanem (2008, p.2), lembrando que são poucos os que hoje discordam do papel educativo das organizações escolares, assim como também são raros aqueles que não admitem a força do convívio familiar à educação das pessoas, contudo, são muitos os questionamentos sobre as formas e conteúdos exibidos pelos meios de comunicação de massa e ocorrem em maior quantidade e intensidade quanto mais se reconhece o poder desses meios na formação de opiniões e nas definições ideológicas de preferências e estilos das pessoas, entre outros fatores, mostrando a contradição entre a aceitação da enorme amplitude e gama de fenômenos educacionais ao se pensar em intervenções em educação tendo em mente apenas o universo da educação escolar. Dourado e Oliveira (2009, p.203) também reforçam a importância em se situar um horizonte analítico para o assunto aqui tratado, lembrando que a educação pode ser entendida como "espaço múltiplo", que reúne inúmeros atores, espaços e dinâmicas formativas que ocorrem de maneira sistemática e assistemática. Nesse ínterim, o ensino formal é tido como importante elemento constitutivo, constituinte, transformador e mantenedor das relações sociais mais amplas.

\subsection{Função social e legislação}

Este tópico pretende abordar as questões da função social das escolas e da legislação vigente, traçando paralelos entre eles quando pertinente. A ideia é contextualizar e comparar aspirações e constatações teóricas sobre as finalidades da educação e realidades do ensino nacional com as disposições legais vigentes.

Para falar em educação escolar, portanto, é prudente situá-la em seu espaço teórico e prático, em sua função, o que representa para a educação como um todo e para 
a sociedade a que pertence, já que, nas palavras do atual ministro da educação Fernando Haddad (2007, p. 6) no PDE (Plano de Desenvolvimento da Educação), a educação não pode ser vista como elemento sócio-cultural isolado, portanto, não se deve tratá-la de maneira simplista ou unilateral, visto que:

(...) o objetivo da política nacional de educação deve se harmonizar com os objetivos fundamentais da própria República, fixados pela Constituição Federal de 1988: construir uma sociedade livre, justa e solidária; garantir o desenvolvimento nacional; erradicar a pobreza e a marginalização e reduzir as desigualdades sociais e regionais e promover o bem de todos, sem preconceitos de origem, raça, sexo, cor, idade e quaisquer outras formas de discriminação. Não há como construir uma sociedade livre, justa e solidária sem uma educação republicana, pautada pela construção da autonomia, pela inclusão e pelo respeito à diversidade. Só é possível garantir o desenvolvimento nacional se a educação for alçada à condição de eixo estruturante da ação do Estado de forma a potencializar seus efeitos. Reduzir desigualdades sociais e regionais se traduz na equalização das oportunidades de acesso à educação de qualidade.

Em verdade, o trecho acima, assim como o restante do plano, inclui duas dimensões da educação que são fundamentais para o entendimento daquilo que se procura aqui trazer à tona em termos de qualidade de ensino, sendo elas a política e a social. No panorama político-legal, além do citado alinhamento constitucional da proposta, há certa concordância com o Art. $1^{\circ}$ da Lei $n^{\circ}$ 9394, que estabelece as diretrizes e bases da educação nacional (conhecida por LDB), no que se refere a uma visão holística sobre o papel desta na sociedade, reconhecendo o direito de acesso a ela para todos e entendendo-a como aquela que "abrange processos formativos que se desenvolvem na vida familiar, na convivência humana, no trabalho, nas instituições de ensino e pesquisa, nos movimentos sociais e organizações da sociedade civil e nas manifestações culturais". Nota-se também um forte posicionamento perante a função social da escola, a qual deve possuir, segundo o ministro, capacidade de mobilizar e transformar realidades sociais de maneira equalizadora e, consequentemente, inclusiva. Por outro lado, Dourado (2011) trata de contextualizar de maneira crítica esse assunto à conjuntura nacional, apontando problemas do PDE não mencionados por Haddad:

Essa lógica e dinâmica política é, ainda, uma realidade no cenário educacional brasileiro, na medida em que não se elaborou a lei complementar que definiria o regime de colaboração recíproca entre os entes federados, manteve-se a indução de políticas, por meio de financiamento de programas e ações priorizadas pela esfera federal, e não se adotou o Plano Nacional de Educação (PNE) como referência base para as políticas educacionais. Adicione-se a isso, mais recentemente, a apresentação pelo MEC de um Plano de Desenvolvimento da Educação (PDE), que não contou, na sua elaboração, com a participação efetiva de setores organizados da sociedade brasileira, de representantes dos sistemas 
de ensino e de setores do próprio Ministério. O PDE apresenta indicações de grandes e importantes ações direcionadas à educação nacional. No entanto, não está balizado por fundamentação técnico-pedagógica suficiente e carece de articulação efetiva entre os diferentes programas e ações em desenvolvimento pelo próprio MEC e as políticas propostas. Tal constatação revela a necessidade de planejamento sistemático, que, após avaliar o conjunto de ações, programas e planos em desenvolvimento, contribua para o estabelecimento de políticas que garantam organicidade entre as políticas, entre os diferentes órgãos do MEC, sistemas de ensino e escola e, ainda, a necessária mediação entre o Estado, demandas sociais e o setor produtivo, em um cenário historicamente demarcado pela fragmentação e/ou superposição de ações e programas, o que resulta na centralização das políticas de organização e gestão da educação básica no país. Trata-se de um cenário ambíguo, no qual um conjunto de programas parece avançar na direção de políticas com caráter inclusivo e democrático, enquanto, de outro lado, prevalece a ênfase gerencial, com forte viés tecnicista e produtivista, que vislumbra nos testes estandardizados a naturalização do cenário desigual em que se dá a educação brasileira (Dourado, 2011, p.928).

Retomando os ideais da Revolução Francesa, é essencial abordar a significação da igualdade e do direito à igualdade, partindo-se da premissa de que esta não é sinônimo de uniformidade, homogeneidade, daí o seu conceito pressupõe - o que não é uma contradição - o direito à diferença, pois diferença não é desigualdade. A desigualdade traz consigo uma valoração de inferior ou superior, de positivo ou negativo, estabelecendo uma relação de poder, de hegemonia entre as partes. A diferença é uma relação horizontalizada (homens são fundamentalmente diferentes de mulheres, mas não superiores, por exemplo). Portanto, igualdade significa isonomia (perante a lei), igualdade diante da justiça, igualdade diante das oportunidades na sociedade, quando esta é democraticamente aberta a todos, igualdade em termos sócio-econômicos, de um mínimo que garanta a vida com dignidade em seu ambiente, igualdade como direito à diferença, à diversidade cultural, à liberdade de escolhas (Benevides, 2010, p.11)

É interessante também trazer aqui a análise de Bordieu (2007, p.53) sobre as questões legais e a função escolar, chamada por Saviani anteriormente de teoria crítico reprodutivista que, de uma maneira parcialmente distinta dos outros autores aqui citados - e pode-se até dizer que mais pessimista sobre essas questões — afirma que "a igualdade formal que pauta a prática pedagógica serve como máscara e justificação para a indiferença no que diz respeito às desigualdades reais diante do ensino e da cultura transmitida, ou melhor dizendo, exigida." Ou seja, para que se favoreça os mais favorecidos e desfavoreça os menos favorecidos basta que a escola ignore, nos conteúdos que transmite, nos métodos, técnicas e critérios de avaliação dessa transmissão, as desigualdades culturais entre crianças de diferentes classes sociais, tratando os educandos, por mais desiguais que sejam, como iguais em direitos e deveres. 
Assim, o sistema escolar na verdade sanciona e perpetua as desigualdades iniciais diante da cultura, sendo que:

\begin{abstract}
É provavelmente por um efeito de inércia cultural que continuamos tomando o sistema escolar como um fator de mobilidade social, segundo a ideologia da "escola libertadora", quando, ao contrário, tudo tende a mostrar que ele é um dos fatores mais eficazes de conservação social, pois fornece a aparência de legitimidade às desigualdades sociais, e sanciona a herança cultural e o dom social tratado como dom natural (Id. Ibid., 2007, p.54)
\end{abstract}

Voltando às questões legais vigentes, após a consideração dessa relevante visão de Bordieu a ressaltar as contradições entre as regulamentações educacionais supostamente democratizantes e as realidades excludentes, a Lei de Diretrizes e Bases da Educação ainda trata, em seu segundo artigo, dos princípios e fins da educação nacional, ressaltando a responsabilidade da família e do Estado que, regidos por princípios de liberdade e apoiados em ideais de solidariedade, devem ter por finalidade o pleno desenvolvimento do educando, preparando-o para o exercício da cidadania, o que pressupõe, por mínimo, o gozo e o respeito dos direitos e deveres civis, além de qualificação para o trabalho, donde se pode ver que, ao menos neste artigo, não são mencionados nem o princípio da igualdade, nem sequer a possibilidade de reconhecimento das notórias desigualdades sociais brasileiras, sejam elas históricas ou subprodutos da modernização capitalista, conforme visto anteriormente nas colocações de Jessé de Souza.

Em relação ao que deveria ser esse desenvolvimento pleno e exercício da cidadania, Vieira et al. (2002) resumem ao afirmar que "cabe à instituição escolar formar cidadãos críticos e participativos, com consciência e clareza das fronteiras em relação aos seus direitos e deveres". Os mesmos autores ainda dissertam sobre os objetivos escolares defendendo uma postura dessas em que hão de extrapolar a mera transmissão de conhecimento sistematizado e conceber, organizar e avaliar o trabalho que produzem no sentido de potencializar o senso crítico dos sujeitos que a compõem. Segundo os mesmos, a concepção e a organização do projeto pedagógico envolvem duas vertentes básicas para que o processo seja permeado por democratização, também um dos princípios legais, e descentralização. A primeira vertente, dizem, está atrelada ao poder, sendo importantes a clareza, o respeito e a compreensão da distribuição do poder entre os atores e a extensão desse poder para cada um. A segunda vertente diz respeito ao conhecimento, que permite aos grupos contribuírem para os resultados do processo em vista da função social anteriormente citada. 
Paro (2007, p.18) coloca que, em relação à dimensão social, a atuação da escola tem sido tanto mais ausente quanto necessária diante dos vários e profundos problemas sociais brasileiros atuais, como as desigualdades e injustiças sociais, a criminalidade, a corrupção, o desemprego, a ausência de consciência ecológica, a violação de direitos, a deterioração dos serviços públicos, a dilapidação do patrimônio social e privatização de bens públicos, entre tantos outros, que só se agravam. Paro (2001a, p.103) reforça dizendo que "neste contexto, a educação poderá contribuir para a transformação social, na medida em que for capaz de servir de instrumento em poder dos grupos sociais dominados em seu esforço de superação da atual sociedade de classes". O currículo essencialmente informativo deixa de lado a necessidade de formação para a ética e a cidadania dos educandos, como se fossem atribuições somente da família, resistindo a propiciar valores e conhecimentos que capacitem e encorajem os alunos a exercerem ativamente sua cidadania no aprimoramento da sociedade. Ao mesmo tempo, desconsidera o marcante crescimento da mídia, enquanto importante formadora de opinião, e a subsequente concorrência de outros meios de comunicação que passam a desenvolver funções antes atribuídas à escola. Ainda assim, sem sombra de dúvida, a principal falha do ensino escolar parece estar na sua omissão na função de educar para a democracia.

\subsection{Financiamento da educação}

Como foi abordada, no primeiro tópico deste capítulo, a questão da quantidade, imprescindível à qualidade educacional, este terceiro tópico teve por finalidade fazer um breve panorama acerca do fornecimento de recursos à educação e ao ensino no Brasil, para que se tivesse fundamentação teórica dessa dimensão ao analisar o estudo de caso proposto.

Segundo as normas legais brasileiras a educação pública deve ser realizada pelos entes federados, União, Estados e Municípios, que têm a responsabilidade pela manutenção e expansão dos ensinos fundamental, médio e superior. A viabilização dos gastos com esses sistemas se dá por uma estrutura de financiamento correspondente. Esse regime de financiamento, diz Abrahão (2005, p.842), deve se pautar pela colaboração, onde parcela dos recursos da União pode ser transferida aos Estados, que incorporam esses recursos aos seus próprios e também podem efetuar transferência aos 
Municípios, que somam isso às suas receitas, mas essas ações supletivas e redistributivas estão condicionadas ao esforço fiscal dos entes, o que significa que a estrutura de financiamento da educação é "fortemente baseada em impostos", visto que uma parcela das arrecadações destes fica reservada aos gastos em educação e tem sido uma medida política crucial para garantir disponibilidade de recursos que se destinem ao cumprimento das responsabilidades do Poder Público nessa área. O Fundo de Manutenção e Desenvolvimento do Ensino Fundamental (o FUNDEF) ressalta a necessidade de estados e municípios cumprirem os dispositivos da Constituição Federal de 88 relativos à vinculação de $25 \%$ das arrecadações de impostos para a manutenção e desenvolvimento do ensino. Outras políticas também reforçam esse cenário, mas com o mesmo viés de estarem muito ligadas ao ensino fundamental apenas, gerando descompensações aos outros níveis educacionais.

Nos últimos anos, mais especificamente de 1990 até 2006, o atendimento da educação voltado para o ensino fundamental teve seu perfil radicalmente alterado, afirma Pinto (2007b, p.879). O principal responsável por essa alteração foi o FUNDEF, que passou a atrelar uma parcela dos recursos destinados à educação ao número de matrículas no ensino fundamental regular, o que provocou uma "municipalização" das redes de ensino em busca desses recursos, em outras palavras, o número de matrículas, consequentemente a oferta de ensino, por escolas municipais aumentou drasticamente, enquanto as matrículas nas escolas de redes estaduais diminuiu bastante. Cresce assim não apenas a participação, mas a relevância das escolas municipais para a educação escolar.

O Fundo de Manutenção e Desenvolvimento da Educação Básica e de Valorização dos Profissionais da Educação (FUNDEB) surge como resposta a uma reivindicação de atores sociais ligados à educação para superar as descompensações financeiras do ensino fundamental em relação aos outros níveis educacionais, incluindo mais equitativamente o ensino infantil e o ensino médio na distribuição desses recursos, aponta Abrahão (2005, p.845), que diz haver também uma importante ressalva a ser feita, já que essa política pública, até a data em questão, deixou fora de suas contas as creches, importantes componentes do ensino infantil e contribuidoras da qualidade da educação escolar, cuja discussão passa necessariamente pela disponibilidade de recursos financeiros. Alguns estudos simulam situações em que o "Fundo completo", aquele que atinja todos os níveis de ensino, dependerá de cenários configurados a partir da relação gasto aluno/ano, levantando hipóteses sobre o "custo aluno/qualidade", que procura 
equacionar a constituição de um fundo amplo e a consequente ampliação dos recursos públicos que dê conta, de fato, das necessidades de manutenção e desenvolvimento de uma educação que se pretende de qualidade.

Saviani (2007, p.1248) afirma que é preciso reconhecer também que o FUNDEB não representou aumento de fato dos recursos financeiros, conforme foi divulgado em junho de 2007, pelo contrário, na ocasião da sanção da lei que regulamentou o fundo, o número de estudantes atendidos pelo Fundo passava de 30 milhões para 47 milhões, portanto, um aumento de $56,6 \%$. Por outro lado, o montante do fundo passou de 35,2 bilhões para 48 bilhões, o que significa um acréscimo de somente $36,3 \%$. Esse fundo passa a abarcar toda a educação básica, sem que, em sua composição, se insiram todos os recursos que estados e municípios devem destinar, por motivo constitucional, à educação. Em consequência, o FUNDEB representa um ganho de gestão, caso os recursos nele alocados sejam efetivamente aplicados e corretamente geridos, mas não um ganho financeiro, por sua natureza contábil que não chega a resolver a questão do financiamento da educação.

Carreira e Pinto (2007) procuram detalhar as condições objetivas para a "garantia de padrão de qualidade", prevista no art. 206 da Constituição Federal, assim como dos "padrões mínimos de qualidade de ensino" descritos como "a variedade e quantidade mínimas, por aluno, de insumos indispensáveis ao desenvolvimento do processo de ensino-aprendizagem", previstos no art. $4^{\circ}$, inc. IX, da Lei de Diretrizes e Bases da Educação, que assume a característica indispensável de insumos, mas não estabelece de forma mais clara as medidas e intensidades da utilização desses recursos, tal qual não especifica com maior precisão as finalidades qualitativas e quantitativas desses padrões mínimos. Assim, edificaram a ideia do "Custo Aluno Qualidade Inicial" (CAQi), cujas bases estão numa matriz que se assenta em dimensões estéticas, num sentido amplo, ambientais, principalmente sobre a interatividade, e de relacionamento humano, com ênfase na participação, dividindo-a em três pilares: da equidade, em termos econômicosociais, de gênero, de etnia, de condições especiais etc.; dos recursos, pensados para condições de estruturas física e organizacionais, para a gestão democrática, para o acesso e a permanência e; das etapas e modalidades de ensino, sendo elas a educação infantil, fundamental, média, de jovens e adultos, do campo, especial, indígena e à distância.

É bom lembrar que o Plano Nacional de Educação de 2001 possuía um grande número de descrições voltadas ao preenchimento desse "vazio" normativo, em que fixava 
meios e metas para alcançar uma ampliação de recursos que satisfizesse boa parte desses anseios, no qual os gastos públicos deveriam atingir a razão de $7 \%$ do Produto Interno Bruto (PIB) brasileiro, mas foi vetado nesse quesito pelo então Presidente Fernando Henrique Cardoso. E vale dizer que, nesta questão, permaneceu assim no governo Lula. Já para o CAQi, "o conceito de qualidade que norteou a proposta referenciou-se em uma perspectiva democrática e de qualidade social", visando o conjunto da população brasileira e não partes dela, assim foram estabelecidos padrões de "construção, equipamentos, número de profissionais, padrões de remuneração, alunos/turma", entre outros, alerta Pinto (2007a). 


\section{METODOLOGIA}

Acompanhando o pensamento de Demo (2008, p. 13-14) supõe-se aqui que a Administração (em seu sentido mais amplo, exposto durante o trabalho) e a Educação podem ser consideradas, num primeiro momento, como ciências primordialmente humanas, justificando para elas uma metodologia relativamente específica ao diferenciálas das ciências exatas e naturais "porque o fenômeno humano possui componentes irredutíveis às características da realidade exata e natural", em outras palavras, que não podem ser explicados por leis universais. Num segundo momento, a administração e a educação também podem ser tidas como ciências sociais, pois seus objetos de estudo são socialmente condicionados, visto que tornam-se incompreensíveis se separados do contexto da inter-relação social. Nesse sentido, a metodologia deste trabalho concorda com as particularidades das ciências humanas e sociais defendidas pelo autor e procura respeitá-las, sendo elas:

1) O objeto de estudo das ciências sociais é histórico e caracteriza-se pela provisoriedade processual de "estar", não de "ser". Portanto, sua objetividade não é definitiva, nem estática, mas se dá em termos de perspectiva, visto que o sujeito pensante e o objeto (sociedade) estão interligados e suas realidades estão em permanente constituição.

2) O ser humano faz história, mas em dadas condições. Entretanto, isso não elimina a possibilidade de consciência histórica desses condicionamentos, de transcendência, de fazer acontecer, de intervir nas realidades, afastando a ideia de que esses condicionantes sejam completamente determinantes aos sujeitos.

3) As realidades sociais manifestam-se em formas mais qualitativas, ou subjetivas, que quantitativas, ou objetivas, o que dificulta o uso de mensurações como critério último de análise, mas não implica em falta de rigor analítico, pelo contrário, representa um desafio a mais à construção científica cuidadosa.

4) O caráter intrinsecamente ideológico das ciências sociais, entendida a ideologia aqui como a maneira pela qual se justificam as posições políticas, os interesses sociais, os valores e preceitos éticos implícitos ou explícitos, as finalidades, enfim, as escolhas e posturas inerentes aos sujeitos. Assim, não se propõe eliminar a ideologia, o que seria ingenuidade, mas ponderá-la criticamente.

Segundo as bases lógicas da investigação buscou-se utilizar neste trabalho o 
método fenomenológico, preconizado por Husserl, não sendo nem dedutivo, nem indutivo, mas, conforme explicam Diehl e Tatim (2006, p. 50):

Preocupa-se com a descrição direta da experiência tal como ela é. A realidade, construída socialmente, é entendida como o compreendido, o interpretado, o comunicado. Assim, ela não é única: existem tantas quantas forem suas interpretações e comunicações, e o sujeito/ator é reconhecidamente importante no processo de construção do conhecimento.

Giles (1989, p.56) exprime o ideal husserliano e sua determinação de estabelecer a Filosofia numa base sólida de racionalidade (racionalidade filosófica enquanto concepção de mundo em seu mais alto grau de elaboração, portanto, importante não confundir com a racionalidade instrumental de alto rigor lógico, coerência e sistematização). Por conseguinte não se pensa em sistemas fechados, acabados, pois a fenomenologia pretende fundamentar-se, por essência, no "dinamismo intencional de uma consciência sempre aberta". Assim, todos os conceitos e termos devem permanecer de uma certa maneira em devir, prontos a se diferenciarem conforme o progresso da análise da consciência e do conhecimento no interior daquilo que já foi primitivamente reconhecido. Trata-se de ver cada vez mais nítida e profundamente, descrevendo com toda a fidelidade os fenômenos observados, vividos, experimentados etc. "Se a ciência for realmente digna desse nome, ela fundamentar-se-á na própria ideia de ciência, e não em suas configurações contingentes". Em outras palavras, é preciso analisar, fundamentar e explicitar a "intenção do sábio, ou seja, a intencionalidade da consciência", deixando claras as relações sujeito-fenômeno. Deve-se entender o fenômeno enquanto presença da coisa, perspectiva dentro da qual a coisa se apresenta. Em vista disso, o ser e o fenômeno sempre vão juntos, indiscerníveis na massa do ser. Para conseguir tal unidade científica requer-se uma conexão "teorético sistemática" que implica no encadeamento e ordem na sucessão da fundamentação do saber.

Traduzindo isso para a metodologia deste trabalho, note-se a ordenação e os conteúdos do referencial teórico alinhados à perspectiva crítica, explicada por Paes de Paula (2008), em suma, como uma perspectiva humanista radical, voltada para a emancipação do homem na "superação da incapacidade de se servir de seu entendimento sem a direção de outrem", que procuram desencadear uma série de teorias e autores que se relacionem e expliquem, sucessivamente, na medida em que tornem evidente ao leitor a essência ideológica deste autor nesses quesitos, em consonância com as ideias trazidas de outros autores, de modo a se demonstrar propositadamente a 
intencionalidade da relação do sujeito (este pesquisador) com os fenômenos (objetos a serem pesquisados), excluindo assim a premissa de neutralidade científica relativa ao padrão dominante de valores da sociedade e visando a assumir uma postura transparente (ou reconhecível, manifesta) e consequentemente, por reconhecimento próprio, inacabada (imperfeita, imprecisa e subjetiva) frente ao tema, por almejar coerência e validade metodológica.

Freire (2006, p.120) porém, atenta para um cuidado nessa relação sobre o conhecimento visto por um autor, mesmo quando este se posiciona firmemente perante o assunto, demonstrando seus métodos de estudo, como pensa e se "aproxima" de um certo tema, a maneira com que se envolve e desenvolve, tanto crítica quanto emocionalmente nessa empreitada. É que a "relação de conhecimento não termina no objeto", não é exclusiva de um sujeito cognoscente com um objeto cognoscível, já que se estende a outro sujeito, a outros sujeitos, tornando-se, no fundo, uma relação sujeitoobjeto-sujeitos.

Já para a abordagem do problema optou-se pela pesquisa preponderantemente qualitativa que permite maior subjetividade para analisar a complexidade da gestão escolar, compreendendo e classificando os processos dinâmicos vividos pelos grupos sociais envolvidos, contribuindo ao processo de gestão e buscando entendimento sobre as particularidades do comportamento dos indivíduos (Diehl e Tatim, 2006, p. 45).

\subsection{Método}

Conforme a proposta de análise, para o procedimento técnico optou-se pelo método do estudo de caso, visto como a melhor opção diante das aspirações e objetivos deste trabalho, caracterizado pelo "estudo profundo e exaustivo do objeto de pesquisa, de maneira que permita seu amplo e detalhado conhecimento, tendo como vantagens a ênfase na totalidade e a simplicidade dos procedimentos" (Diehl e Tatim, 2006, p.48).

O intuito específico foi de realizar um estudo de caso em uma escola municipal de ensino fundamental de Bebedouro, concordante com a pesquisa e que tenha passado pelo INDIQUE. O critério para a escolha do município de Bebedouro ocorreu pelo fato de que todas as escolas municipais da cidade fizeram a avaliação proposta pelo INDIQUE e pela conveniência de certa proximidade com o município de Ribeirão Preto, local onde reside o autor. A escolha do ensino fundamental é dada por sua relevância à gestão 
democrática relacionada à fase de formação dos alunos desse período mencionada no capítulo "Qualidade de ensino e gestão escolar democrática" e a opção do ensino público deu-se pela acessibilidade às informações e pela convicção sobre incompatibilidade entre educação privada, cujos interesses são essencialmente mercadológicos, e democracia, concordando com a visão de Tragtenberg (1990). Já a opção pelo estudo de caso se dá pela prudência alertada por determinados autores para este método em buscar o aprofundamento da análise, em detrimento da escala, nos termos em que Paro (2001a, p.41) se refere à questão da representatividade, sendo que aquilo que torna relevante um estudo de caso não é a representatividade estatística dos fenômenos, mas sim, por menor que ela seja - de uma parcela do conjunto em relação a esse todo - o importante é que ela valha pela sua "exemplaridade".

\subsection{O INDIQUE}

Vieira et al. (2002) criticam, num primeiro momento, alguns aspectos ainda vigentes relacionados às comuns avaliações objetivas de desempenho que perpetuam, na prática, uma visão tradicionalista e simplista desta, já que estão centrados na relação aluno-professor-aprendizagem, baseados em modelos de meritocracia , os quais remetem a uma abordagem competitiva, o que é inconsistente e incoerente com os objetivos da avaliação que visa ao aperfeiçoamento da qualidade da educação, pois se limitam às quatro paredes da sala de aula e geram resultados insuficientes ou até mesmo equivocados. Isto ocorre porque essa percepção desconsidera o processo de desenvolvimento do homem na sua pluri dimensionalidade, complementam. Propõem, após revisões históricas e conceituais do tema, que as avaliações sejam calcadas numa perspectiva transformadora, com enfoque humanizador, que busquem avaliar de diversas maneiras, sistemáticas, participativas, quantitativas, qualitativas, globais, individuais e coletivas, envolvendo o maior número possível de atores dos processos reflexivos e da construção da prática da escola em ações continuadas. Não basta que a avaliação dimensione desempenhos pontuais ou indique habilidades, o que defendem é que ela precisa mostrar rumos, estabelecer relações e atribuir significados.

É nesse sentido que este trabalho procura se valer de um instrumento de avaliação qualitativo que fuja aos restritos parâmetros quantitativos mais difundidos e que se enquadre nas características qualitativas consideradas mais adequadas à complexidade 
inerente ao tema, evitando assim o empobrecimento analítico, já que, conforme Motta (2001, p.100), "a hegemonia da razão instrumental pressupõe a desvalorização do pensamento ético e da ação afetiva" onde a multidimensionalidade não tem espaço e a diferença vira sinônimo de ameaça ao poder. Essa característica é contrária ao que aqui se busca em termos de análise, pois, como lembra Paro (2007, p.22), "o produto da educação - o ser humano educado - não se deixa captar por mecanismos convencionais de aferição de qualidade", sendo que uma aproximação mais adequada seria a avaliação dos processos que visam à qualidade, representados aqui pela avaliação da gestão democrática.

Isso exige investigar a anatomia das práticas pedagógicas e das demais relações sociais que acontecem no dia a dia da escola, para compreender seus problemas, considerar suas virtudes e avaliar suas potencialidades. Ao mesmo tempo, é preciso conhecer a opinião dos atores (professores, alunos, pais, direção e demais funcionários), seus interesses e expectativas, sua visão da educação e dos problemas a ela correlatos, bem como os determinantes de suas posturas e sua disposição para aderir a novas propostas (Paro, 2007, p.27-28).

O INDIQUE, critério de avaliação e seleção do objeto de estudo para esta pesquisa, não só demonstra ter essas características em seu formato, como apresenta uma proposta em termos de essência e finalidade, consonante às teorias e anseios aqui apresentados, visto que a própria metodologia do projeto incentiva a participação da comunidade escolar e do corpo docente na construção de um plano de ação para a escola. Veja-se a seguir um trecho de texto que clarifica melhor essas questões:

É muito comum ouvir que o ensino público no Brasil é de má qualidade. Mas o que é qualidade? Será que uma escola considerada de qualidade cem anos atrás ainda hoje seria vista assim? Será que uma escola boa para a população que vive no interior da floresta amazônica também é boa para quem mora nos centros urbanos?

Como todos vivemos num mesmo país e num mesmo tempo histórico, é provável que compartilhemos muitas noções gerais sobre o que é uma escola de qualidade. A maioria das pessoas certamente concorda com o fato de que uma escola boa é aquela em que os alunos aprendem coisas essenciais para sua vida, como ler e escrever, resolver problemas matemáticos, conviver com os colegas, respeitar regras, trabalhar em grupo. Quem pode definir bem esse conceito de qualidade na escola e ajudar nas orientações gerais sobre essa qualidade, de acordo com os contextos socioculturais locais, é a própria comunidade escolar. Não existe um padrão ou uma receita única para uma escola de qualidade. Qualidade é um conceito dinâmico, reconstruído constantemente. Cada escola tem autonomia para refletir, propor e agir na sua busca pela qualidade da educação.

Os Indicadores da Qualidade na Educação foram criados para ajudar a comunidade escolar a avaliar e melhorar a qualidade da escola. Este é seu objetivo principal. Compreendendo seus pontos fortes e fracos, a escola tem condições de intervir para melhorar sua qualidade conforme seus próprios critérios 
e prioridades. Para tanto, identificamos sete elementos fundamentais - aqui nomeados como dimensões - que devem ser considerados pela escola na reflexão de sua qualidade. Para avaliar essas dimensões, foram criados alguns sinalizadores de qualidade de aspectos importantes da realidade escolar: os indicadores (INDIQUE, 2007).

As sete dimensões a que o texto se refere são: ambiente educativo; prática pedagógica e avaliação; ensino e aprendizagem da leitura e da escrita; gestão escolar democrática; formação e condições de trabalho dos profissionais da escola; ambiente físico escolar e; acesso e permanência dos alunos na escola. Já os indicadores, neste caso, seriam sinais reveladores de aspectos referentes à realidade escolar nessas dimensões (INDIQUE, 2007).

Por fim, a avaliação proposta pelo INDIQUE não possui um modelo pré-definido de execução, já que defende não existir uma forma única de aplicação, mas sugere e recomenda maneiras para tal, e também reforça seus pontos principais, entre eles a participação e mobilização de todos os atores (pais, alunos, professores, funcionários etc.) da comunidade escolar, atuantes ou não na rotina da escola.

\subsection{Procedimentos}

Utilizou-se, para a parte estruturada da pesquisa, o levantamento das informações apresentadas no relatório elaborado pelo processo do INDIQUE e os dados e informações referentes ao Plano Gestor da EMEB Alfredo Naime. Foram feitas entrevistas semiestruturadas, cujo roteiro de entrevista encontra-se nos anexos deste trabalho, e nãoestruturadas, a respeito do tema, com representantes de todos os principais atores escolares, sendo eles professores, alunos, pais, direção e demais funcionários. Também foram feitos acompanhamentos e observações presenciais na EMEB Alfredo Naime, tanto em suas atividades rotineiras (trabalhos, aulas e oficinas) quanto em suas atividades específicas (reuniões de professores, de conselho escolar e dos atores em geral, no caso da devolutiva dos resultados do INDIQUE). A elaboração do roteiro de entrevistas semiestruturadas buscou seguir os formatos e conteúdos de questionamento encontrados em Paro (2007) e Mendonça (2000). Ainda assim, foram feitos testes prévios do roteiro de entrevistas semi-estruturadas a fim de adequações pertinentes ao contexto escolar e à dinâmica das conversações.

Ao todo foram feitas dez visitas à EMEB Alfredo Naime que duraram cerca de três 
horas cada, em média, todas elas no primeiro semestre de 2011, sendo que em quatro visitas foram feitas as entrevistas semi-estruturadas aos profissionais da escola, em outras duas visitas houve participação em reuniões sobre o INDIQUE, em outras duas visitas fez-se acompanhamento de atividades escolares e outras duas visitas constituíram-se de conversas informais e entrevistas não-estruturadas a alunos, exalunos, pais e professores. É importante destacar que a recepção dos atores escolares a este pesquisador foi muito simpática e solícita, em todas as ocasiões, o que facilitou o acesso e a obtenção de informações, principalmente nas conversas informais, as quais foram anotadas após cada visita para composição das análises e conclusões deste trabalho.

A partir das entrevistas (todas elas gravadas integralmente em áudio e em anexo no $C D$ que acompanha este trabalho), dos acompanhamentos (cuja reunião da devolutiva dos resultados do INDIQUE foi gravada integralmente e também consta no CD em anexo), das informações obtidas pelo Plano Gestor e pelo relatório elaborado no processo do INDIQUE, foram elaboradas análises dessas entrevistas, acompanhamentos e informações que possibilitassem algumas conclusões, pautadas pelo referencial teórico aqui disposto, visando o objetivo deste trabalho em relação à EMEB Alfredo Naime. 


\section{ANÁLISES DO INDIQUE E DAS ENTREVISTAS}

\subsection{Análise do INDIQUE na Alfredo Naime}

O INDIQUE (Indicadores da Qualidade na Educação), como dito outras vezes ao longo dessa dissertação, possui metodologia de avaliação qualitativa e democrática, em que participam todos os atores escolares opinando e discutindo de maneira não paramétrica sobre dimensões essenciais do ensino e da escola, a fim de chegar a um plano de ação para a escola coletivamente elaborado. O material e mais informações que concernem ao INDIQUE (2009) podem ser encontrados via internet, conforme indicação de sítio eletrônico que consta na bibliografia deste trabalho.

As análises aqui presentes do "Plano de Ação para o Ensino Fundamental" (em anexo) gerado após o processo do INDIQUE são fruto do acompanhamento, observação e participação deste autor na reunião de apresentação e discussão do Plano para a comunidade, nas entrevistas feitas aos atores escolares e numa reunião do HTPC (informações verbais) $^{9}$ (horário de trabalho pedagógico coletivo, em que participam professores e corpo gestor) voltada para a reflexão sobre as medidas necessárias para a consecução das ações propostas no Plano.

Antes do início das análises é preciso evidenciar que o processo do INDIQUE na EMEB Alfredo Naime não seguiu estritamente a metodologia proposta pois, conforme o relato de professores do Ciclo I da escola, no dia de sua aplicação, a pessoa responsável, que é ligada ao DEMEC, não incluiu nem orientou os professores a também participarem ativamente, mas apenas acompanhar e ajudar operacionalmente na execução do processo, o que pode ser considerado um desvio metodológico grave, já que diz respeito à uma característica fundamental dessa avaliação, a perspectiva democrática. Por isso é necessário destacar que o Plano de Ação não contém a visão dos professores, o que restringe, mas não retira o valor dos seus conteúdos. Por fim, é também importante dizer que o Plano de Ação aqui apresentado possui somente os indicadores em que foi apontado algum problema referente à dimensão avaliada, sendo que os outros indicadores contidos na proposta do INDIQUE foram avaliados como satisfatórios e, por conseguinte, não geraram propostas de ações porque, no entendimento dos participantes, a escola já atendia a contento àquela questão.

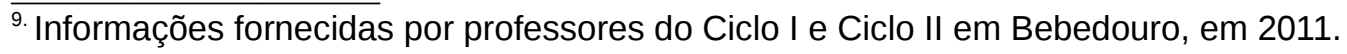




\begin{tabular}{|c|c|c|c|c|c|c|}
\hline \multicolumn{7}{|c|}{ Quadro 5 - Ambiente educativo } \\
\hline \multicolumn{7}{|c|}{ Plano de Ação para o Ensino Fundamental da EMEB Alfredo Naime } \\
\hline Dimensão & Indicador & Problema & Ação proposta & $\begin{array}{l}\text { Objetivo } \\
\text { da ação }\end{array}$ & Responsáveis & Prazo \\
\hline $\begin{array}{l}\text { Ambiente } \\
\text { educativo }\end{array}$ & Alegria & $\begin{array}{l}\text { Tempo de } \\
\text { permanência na } \\
\text { escola }\end{array}$ & $\begin{array}{l}\text { É uma escola de período } \\
\text { integral que atende em sua } \\
\text { maioria a zona rural. Por isso } \\
\text { não temos como diminuir o } \\
\text { tempo de permanência dos } \\
\text { alunos na escola. }\end{array}$ & & $\begin{array}{l}\text { Pais dos } \\
\text { alunos }\end{array}$ & \\
\hline
\end{tabular}

Fonte: Plano de Ação para o Ensino Fundamental da EMEB Alfredo Naime, INDIQUE 2011.

O problema do tempo de permanência na escola foi levantado pelos pais e alunos, não no intuito de que as crianças passassem necessariamente menos horas na escola, mas que a rotina pudesse ser modificada, tendo em vista que boa parte do dia elas ficavam lá. Uma sugestão deles para a questão foi lembrada na reunião de apresentação do INDIQUE à comunidade pela diretora Sueli (informações verbais) ${ }^{10}$, em que pediam um tempo de descanso para os alunos, ou mesmo repouso, após refeições, principalmente do almoço. A queixa para diminuir a carga horária realça ainda uma posição dos alunos, mas reforça que eles não consideraram a importância desse tempo de permanência na escola e a tendência atual para o ensino de aumentar a carga horária, diz Sueli, no que os pais concordaram. A ação proposta não atende a essa demanda e foi justificada também pelo seu impeditivo legal. Como resultado, os alunos não terão a demanda que apresentaram atendida. A este trabalho pareceu bastante razoável o pedido dos alunos, que alegam ter sono logo após as refeições, fator este que obviamente atrapalha 0 acompanhamento das aulas nesse período se não lhes for permitida uma pausa para descansar. 


\begin{tabular}{|c|c|c|c|c|c|c|}
\hline \multicolumn{7}{|c|}{ Quadro 6 - Ensino e aprendizagem da escrita e da leitura } \\
\hline \multicolumn{7}{|c|}{ Plano de Ação para o Ensino Fundamental da EMEB Alfredo Naime } \\
\hline Dimensão & Indicador & Problema & Ação proposta & $\begin{array}{l}\text { Objetivo } \\
\text { da ação }\end{array}$ & Responsáveis & Prazo \\
\hline \multirow[t]{2}{*}{$\begin{array}{l}\text { Ensino e } \\
\text { aprendiza } \\
\text {-gem da } \\
\text { escrita e } \\
\text { da leitura }\end{array}$} & $\begin{array}{l}\text { Existência } \\
\text { de práticas } \\
\text { alfabetiza- } \\
\text { doras na } \\
\text { escola }\end{array}$ & $\begin{array}{l}\text { Falta de } \\
\text { informações } \\
\text { sobre a } \\
\text { prática da } \\
\text { escola }\end{array}$ & $\begin{array}{l}\text {-Na reunião de pais, } \\
\text { informar a prática } \\
\text { pedagógica da escola e } \\
\text { do professor } \\
\text {-Informar o que está } \\
\text { sendo feito para recuperar } \\
\text { os alunos com } \\
\text { dificuldades e os } \\
\text { investimentos feitos para } \\
\text { garantir a qualidade do } \\
\text { ensino pela escola e pelo } \\
\text { DEMEC } \\
\text {-Atendimento individual } \\
\text { aos pais dos alunos com } \\
\text { dificuldades de } \\
\text { aprendizagem pelo } \\
\text { professor e coordenador }\end{array}$ & $\begin{array}{l}\text { Que os pais } \\
\text { fiquem } \\
\text { cientes do } \\
\text { que é feito } \\
\text { para seus } \\
\text { filhos na } \\
\text { escola em } \\
\text { relação a } \\
\text { prática } \\
\text { pedagógica } \\
\text { e de como } \\
\text { eles } \\
\text { também } \\
\text { podem } \\
\text { auxiliá-los }\end{array}$ & $\begin{array}{l}\text { Direção, } \\
\text { coordenação, } \\
\text { professores e } \\
\text { pais }\end{array}$ & $\begin{array}{l}\text { No final do } \\
1^{0} \\
\text { bimestre, } \\
\text { tornando- } \\
\text { se contínua } \\
\text { no decorrer } \\
\text { do ano } \\
\text { letivo }\end{array}$ \\
\hline & $\begin{array}{l}\text { Acesso e } \\
\text { bom } \\
\text { aproveita- } \\
\text { mento da } \\
\text { biblioteca }\end{array}$ & $\begin{array}{l}\text { Necessidade } \\
\text { de uma } \\
\text { pessoa para } \\
\text { cuidar do } \\
\text { acervo da } \\
\text { biblioteca e } \\
\text { instalações de } \\
\text { computadores } \\
\text { para aprimora- } \\
\text { mento da } \\
\text { leitura e } \\
\text { escrita }\end{array}$ & $\begin{array}{l}\text { 1-Elaborar um } \\
\text { projeto,onde os alunos da } \\
\text { 8asérie irão ser } \\
\text { responsáveis pela } \\
\text { organização, divulgação e } \\
\text { empréstimo de livros para } \\
\text { alunos e comunidade } \\
\text { 1.1-Elaboração de um } \\
\text { cronograma de } \\
\text { atendimento com } \\
\text { dia,horário e dois alunos } \\
\text { para cada dia de } \\
\text { atendimento } \\
\text { 2-Os computadores já } \\
\text { estão na escola,mas a } \\
\text { instalação depende de } \\
\text { recursos } \\
\text { financeiros,licitações e de } \\
\text { outros departamentos da } \\
\text { prefeitura }\end{array}$ & $\begin{array}{l}\text { Melhorar e } \\
\text { garantir o } \\
\text { acesso dos } \\
\text { alunos e } \\
\text { comunidade } \\
\text { a biblioteca }\end{array}$ & $\begin{array}{l}\text { 1-professor } \\
\text { da aula de } \\
\text { leitura das } \\
\text { oficinas e } \\
\text { alunos da } \\
8^{a} \text { série com a } \\
\text { colaboração } \\
\text { dos gestores } \\
\text { da escola } \\
\text { 2-DEMEC }\end{array}$ & $\begin{array}{l}1 \text { e } 1.1- \\
\text { mês de } \\
\text { maio } \\
\text { 2-O mais } \\
\text { breve } \\
\text { possível }\end{array}$ \\
\hline
\end{tabular}

Fonte: Plano de Ação para o Ensino Fundamental da EMEB Alfredo Naime, INDIQUE 2011.

As ações propostas para a solução do problema da falta de informações sobre a prática da escola para a comunidade já estão sendo tomadas pela escola por meio de reuniões e boletins informativos de acompanhamento que serão elaborados bimestralmente e apresentados aos pais. $O$ atendimento individual de professores aos pais dos alunos com dificuldades de aprendizagem é exceção e ainda não está sendo feito, mas está sendo discutido pelos professores.

O problema de pessoas para cuidar da biblioteca já foi praticamente resolvido, mas a questão da instalação dos computadores tem sido um entrave a diversas atividades almejadas pelos atores escolares. Segundo relatos de professores e da coordenadora pedagógica na reunião do HTPC para discussão do INDIQUE, a sala de informática já 
está reservada, os computadores já estão na sala, mas ainda fechados nas suas caixas, pois não podem ser abertos sem uma autorização simples do Prefeito de Bebedouro, cuja requisição pela escola já foi feita, porém aguardando resposta a dois anos. Enquanto isso os alunos estão sem acesso à atividades escolares digitais práticas por um impeditivo burocrático supérfluo.

Outra questão suscitada nessa reunião do HTPC foi o questionamento sobre os investimentos que não estão sendo feitos pelo DEMEC e pela Prefeitura de Bebedouro para garantir a qualidade de ensino, como melhorias na remuneração dos profissionais da educação, por exemplo, para que os professores não precisassem dar tantas aulas em dois ou três turnos a fim de conseguir salários mais dignos (conforme constatado nas entrevistas), sobrando tempo para que preparassem melhor suas aulas e exercessem atividades extracurriculares importantes à suas formações e interações com a comunidade, mostrando o viés do Plano em não conter a perspectiva dos professores.

\begin{tabular}{|c|c|c|c|c|c|c|}
\hline \multicolumn{7}{|c|}{ Quadro 7 - Prática pedagógica e avaliação } \\
\hline \multicolumn{7}{|c|}{ Plano de Ação para o Ensino Fundamental da EMEB Alfredo Naime } \\
\hline Dimensão & Indicador & Problema & Ação proposta & $\begin{array}{l}\text { Objetivo } \\
\text { da ação }\end{array}$ & Responsáveis & Prazo \\
\hline $\begin{array}{l}\text { Prática } \\
\text { pedagógica } \\
\text { e avaliação }\end{array}$ & \begin{tabular}{|l} 
Projeto \\
político \\
pedagógico \\
definido e \\
conhecido \\
por todos
\end{tabular} & $\begin{array}{l}\text { Pais, alunos e } \\
\text { funcionários } \\
\text { sabem da } \\
\text { existência do } \\
\text { PPP, porém } \\
\text { nem todos } \\
\text { conhecem } \\
\text { seu conteúdo }\end{array}$ & $\begin{array}{l}\text { 1- Nas reuniões de pais e } \\
\text { momentos com os alunos } \\
\text { passar informações do } \\
\text { PPP } \\
\text { 2- Aproveitar o projeto de } \\
\text { jornal da } 7^{a} \text { série e dedicar } \\
\text { uma página, para que os } \\
\text { alunos passem } \\
\text { informações sobre o PPP } \\
\text { para todos da escola e } \\
\text { comunidade } \\
\text { 3-Na elaboração do novo } \\
\text { PPP para o próximo ano } \\
\text { contar com a participação } \\
\text { dos funcionários, alunos e } \\
\text { membros da comunidade } \\
\text { utilizando o resultado da } \\
\text { avaliação do Indique }\end{array}$ & $\begin{array}{l}\text { Que todos } \\
\text { conheçam o } \\
\text { conteúdo do } \\
\text { PPP e } \\
\text { participem } \\
\text { ativamente da } \\
\text { elaboração do } \\
\text { próximo }\end{array}$ & $\begin{array}{l}\text { - Equipe } \\
\text { escolar } \\
\text { - Alunos } \\
\text { - Professor de } \\
\text { informática e } \\
\text { produção } \\
\text { textual }\end{array}$ & $\begin{array}{l}\text { 1-Reunião de } \\
\text { pais, dia 11/05 } \\
\text { 2-A proposta } \\
\text { para o jornal } \\
\text { da escola } \\
\text { (alunos e } \\
\text { professores) } \\
\text { em Abril } \\
\text { 2.1-Primeiro } \\
\text { jornal com } \\
\text { informações } \\
\text { do PPP no } \\
\text { segundo } \\
\text { bimestre } \\
\text { 3-Para } \\
\text { elaboração do } \\
\text { próximo PPP } \\
\text { iniciar reuniões } \\
\text { no quarto } \\
\text { bimestre }\end{array}$ \\
\hline
\end{tabular}

Fonte: Plano de Ação para o Ensino Fundamental da EMEB Alfredo Naime, INDIQUE 2011.

As propostas deste quadro da "Prática pedagógica e avaliação" são muito significativas em termos de democratização da gestão escolar, de acordo com o referencial teórico, pois a escola passou a estender a elaboração do Projeto Político 
Pedagógico a todos os atores escolares e o fez de maneiras distintas, de modo a elucidar os agora participantes ativos da gênese do PPP sobre seus conteúdos e sua relevância, assim como transmitir essas informações por diferentes vias de comunicação visando atingir o maior número possível de pessoas envolvidas, num louvável esforço democrático, transformando o PPP em verdadeiro instrumento de expressão da comunidade escolar na procura e afirmação de sua identidade. Lamenta-se somente que o projeto do jornal da sétima série, que chega aos pais em suas casas, e a divulgação do PPP neste jornal não tenham dado certo ainda, já que os computadores da sala de informática que estão desativados até o momento são necessários para a concretização do projeto.

\begin{tabular}{|c|c|c|c|c|c|c|}
\hline \multicolumn{7}{|c|}{ Quadro 8 - Gestão escolar democrática } \\
\hline \multicolumn{7}{|c|}{ Plano de Ação para o Ensino Fundamental da EMEB Alfredo Naime } \\
\hline Dimensão & Indicador & Problema & Ação proposta & $\begin{array}{l}\text { Objetivo } \\
\text { da ação }\end{array}$ & Responsáveis & Prazo \\
\hline \multirow[t]{2}{*}{$\begin{array}{l}\text { Gestão } \\
\text { escolar } \\
\text { democrática }\end{array}$} & $\begin{array}{l}\text { Acesso, } \\
\text { compreensão } \\
\text { e uso dos } \\
\text { indicadores } \\
\text { oficiais de } \\
\text { avaliação da } \\
\text { escola e das } \\
\text { redes de } \\
\text { ensino }\end{array}$ & $\begin{array}{l}\text { Somente } \\
\text { professores e } \\
\text { equipe gestora } \\
\text { têm acesso a } \\
\text { informações de } \\
\text { avaliação da } \\
\text { escola }\end{array}$ & $\begin{array}{l}\text { - Colocar no mural da } \\
\text { escola as informações } \\
\text { sobre as avaliações } \\
\text { realizadas } \\
\text { - Divulgar essas } \\
\text { informações no Blog da } \\
\text { escola }\end{array}$ & $\begin{array}{l}\text { Maior } \\
\text { circulação } \\
\text { das } \\
\text { informações } \\
\text { na escola e } \\
\text { fora dela }\end{array}$ & $\begin{array}{l}\text {-Professor de } \\
\text { matemática e } \\
\text { de informática } \\
\text { - Alunos } \\
\text { - Colaboração } \\
\text { da equipe } \\
\text { gestora }\end{array}$ & $\begin{array}{l}\text {-Após a } \\
\text { realização } \\
\text { das } \\
\text { avaliações e } \\
\text { divulgação } \\
\text { dos } \\
\text { resultados }\end{array}$ \\
\hline & $\begin{array}{l}\text { Participação } \\
\text { em programas } \\
\text { de repasse de } \\
\text { recursos } \\
\text { financeiros }\end{array}$ & $\begin{array}{l}\text { Utilização dos } \\
\text { recursos } \\
\text { financeiros não } \\
\text { é discutida } \\
\text { democratica- } \\
\text { mente }\end{array}$ & $\begin{array}{l}\text { Esclarecimento sobre a } \\
\text { utilização das verbas e } \\
\text { o papel dos conselhos } \\
\text { na democracia }\end{array}$ & $\begin{array}{l}\text { Esclarecer } \\
\text { dúvidas. }\end{array}$ & Direção & $\begin{array}{l}\text { Próxima } \\
\text { reunião de } \\
\text { pais }\end{array}$ \\
\hline
\end{tabular}

Fonte: Plano de Ação para o Ensino Fundamental da EMEB Alfredo Naime, INDIQUE 2011.

O problema do acesso a informações de avaliação da escola já está sendo resolvido. Avisos sobre as avaliações da escola serão colocados nos corredores, transmitidos pelos alunos aos pais e comunicados nas reuniões. Contudo, nesta dissertação, conforme o que foi abordado sobre o uso de testes padronizados, entende-se que a exposição dessas informações, principalmente aquelas que contenham indicadores de desempenho das avaliações de larga escala feitas pelos governos estadual e federal, como a Prova Brasil, o SAEB (Sistema de Avaliação da Educação Básica) e o SARESP (Sistema de Avaliação do Rendimento Escolar do Estado de São Paulo), deve ser cautelosa, de modo a não transformá-los em indicadores de qualidade de ensino, ou falta 
de qualidade, ou ainda como parâmetros comparativos com outras escolas, entendendo que a qualidade é uma dimensão ampla que não pode ser simplesmente mensurada a partir de avaliações restritas em conteúdo, sistemáticas em suas formas e bastante específicas em seus objetivos. A comparação com outras instituições a partir desses índices também não deve ser feita, na compreensão aqui trazida, pois a realidade de cada escola é única, mesmo que seus ambientes sejam muito similares, não podendo ser reduzida a apontamentos estritamente numéricos.

Quanto à discussão democrática da utilização dos recursos financeiros, é uma requisição justa, mas parece recair apenas sobre a responsabilidade do diretor, o que pôde ser percebido como pouco significante na entrevista com a diretora Sueli, já que, segundo a mesmo, a verba sobre a qual a direção da escola tem autonomia para atuar é muito pequena, cerca de dois mil e quinhentos reais anuais. É importante que o uso desse recurso, ainda que pequeno, seja discutido com a comunidade, mas quase todo o orçamento da escola depende dos desígnios do DEMEC, e este da Prefeitura. Portanto, a real democratização e esclarecimento da utilização dos recursos financeiros para a escola ocorreria se esta fosse debatida pela comunidade com a diretoria e o DEMEC $\underline{e} a$ Prefeitura, ou seja, com as instâncias superiores de poder. Seria, no mínimo, um canal de reivindicação da população para investimentos em educação.

\begin{tabular}{|c|c|c|c|c|c|c|}
\hline \multicolumn{7}{|c|}{ Quadro 9 - Formação de condições de trabalho dos profissionais da escola } \\
\hline \multicolumn{7}{|c|}{ Plano de Ação para o Ensino Fundamental da EMEB Alfredo Naime } \\
\hline Dimensão & Indicador & Problema & Ação proposta & $\begin{array}{l}\text { Objetivo } \\
\text { da ação }\end{array}$ & Responsáveis & Prazo \\
\hline \multirow{3}{*}{$\begin{array}{l}\text { Formação de } \\
\text { condições de } \\
\text { trabalho dos } \\
\text { profissionais } \\
\text { da escola }\end{array}$} & $\begin{array}{l}\text { Formação } \\
\text { inicial e } \\
\text { continuada }\end{array}$ & $\begin{array}{l}\text { Dificuldade na } \\
\text { formação e no } \\
\text { trabalho com } \\
\text { alunos com } \\
\text { deficiência }\end{array}$ & $\begin{array}{l}\text { Viabilizar mais cursos de } \\
\text { formação em horário de } \\
\text { aula para os professores } \\
\text {-Orientação para os } \\
\text { coordenadores } \\
\text { realizarem estudos no } \\
\text { HTPC sobre o assunto }\end{array}$ & $\begin{array}{l}\text {-Auxiliar o } \\
\text { trabalho do } \\
\text { professor em } \\
\text { sala de aula } \\
\text { com alunos de } \\
\text { inclusão }\end{array}$ & $\begin{array}{l}\text { DEMEC - } \\
\text { Equipe da } \\
\text { coordenação } \\
\text { pedagógica }\end{array}$ & $\begin{array}{l}\text { Durante o } \\
\text { ano letivo }\end{array}$ \\
\hline & $\begin{array}{l}\text { Suficiência e } \\
\text { estabilidade } \\
\text { da equipe } \\
\text { escolar }\end{array}$ & $\begin{array}{l}\text { Número de } \\
\text { funcionários } \\
\text { insuficiente e } \\
\text { contratação de } \\
\text { uma equipe } \\
\text { multidisciplinar }\end{array}$ & $\begin{array}{l}\text { Informar a comunidade } \\
\text { sobre as razões da alta } \\
\text { rotatividade dos } \\
\text { professores e número } \\
\text { insuficientes de } \\
\text { funcionários. } \\
\text { Contratar funcionários } \\
\end{array}$ & $\begin{array}{l}\text { - Esclarecer } \\
\text { dúvidas } \\
\text { - E garantir um } \\
\text { bom } \\
\text { funcionamento } \\
\text { da escola }\end{array}$ & $\begin{array}{l}\text { Direção, } \\
\text { Demec e RH }\end{array}$ & $\begin{array}{l}\text { Esclarecer } \\
\text { dúvidas } \\
\text { imediato e } \\
\text { contratação } \\
\text { o mais } \\
\text { rápido } \\
\text { possível } \\
\end{array}$ \\
\hline & $\begin{array}{l}\text { Assiduidade } \\
\text { da equipe } \\
\text { escolar }\end{array}$ & $\begin{array}{l}\text { Número de } \\
\text { faltas }\end{array}$ & $\begin{array}{l}\text { - Conscientização do } \\
\text { compromisso com a } \\
\text { educação através de } \\
\text { conversas em grupo }\end{array}$ & Conscientizar & Equipe gestora & Curto prazo \\
\hline
\end{tabular}

Fonte: Plano de Ação para o Ensino Fundamental da EMEB Alfredo Naime, INDIQUE 2011. 
O problema da dificuldade na formação e no trabalho com alunos com deficiência está sendo discutido pelos professores. Na reunião do HTPC sobre o INDIQUE alguns professores do ciclo II comentavam que não estavam preparados para atender alunos com deficiências por duas razões: a primeira é que eles não tinham formação especializada no tratamento dessas pessoas especificamente, o que acreditavam ser tarefa difícil e exigir uma formação de base voltada para esses sujeitos e não um curso que pudesse teoricamente capacitá-los para tal; a segunda razão é que alguns ali mostravam clara discordância em que a escola atendesse a alunos com deficiências porque esta não possui estrutura física nem competências humanas em seu corpo profissional para esse atendimento (realmente pôde-se observar que a escola não possui as adaptações de acesso para deficientes) e também porque não haviam se formado com aquele objetivo, pois isso não dizia respeito às atribuições de professores regulares, mas a professores com essa especialização. Entende-se aqui que a escola e o DEMEC devem providenciar condições e recursos materiais e humanos para o acesso desses alunos, mas isso não ausenta os "professores regulares" da responsabilidade de também atender a esses alunos, para que essa parcela de pessoas não seja excluída dos processos educativos.

O número de professores e funcionários insuficiente é outro problema que depende mais do DEMEC e da Prefeitura que qualquer outra entidade, mas as informações sobre a alta rotatividade e a conscientização do compromisso com a educação já estão sendo realizados pela escola para atendimento à requisição da comunidade e possível diminuição do número de faltas no corpo docente.

\begin{tabular}{|c|c|c|c|c|c|c|}
\hline \multicolumn{7}{|c|}{ Quadro 10 - Ambiente físico escolar } \\
\hline \multicolumn{7}{|c|}{ Plano de Ação para o Ensino Fundamental da EMEB Alfredo Naime } \\
\hline Dimensão & Indicador & Problema & Ação proposta & $\begin{array}{l}\text { Objetivo } \\
\text { da ação }\end{array}$ & Responsáveis & Prazo \\
\hline $\begin{array}{l}\text { Ambiente } \\
\text { físico } \\
\text { escolar }\end{array}$ & $\begin{array}{l}\text { Qualidade } \\
\text { do } \\
\text { ambiente } \\
\text { físico } \\
\text { escolar }\end{array}$ & $\begin{array}{l}\text { Falta de infra } \\
\text { estrutura, } \\
\text { acessibilidade } \\
\text { para pessoas } \\
\text { com } \\
\text { deficiências }\end{array}$ & $\begin{array}{l}\text { 1- Mobilizar a comunidade para } \\
\text { reivindicar a cobertura da quadra } \\
\text { 2- Já fizemos uma parceria com } \\
\text { o fisk através do projeto do } \\
\text { superação jovem para reativar a } \\
\text { horta e o paisagismo } \\
\text { 3- Investir no visual da biblioteca } \\
\text { 4- Construções de rampas e } \\
\text { ambientes adequados para } \\
\text { deficientes }\end{array}$ & $\begin{array}{l}\text { Melhorar a } \\
\text { qualidade do } \\
\text { espaço } \\
\text { utilizado } \\
\text { pelos alunos }\end{array}$ & $\begin{array}{l}\text { 1- Direção e } \\
\text { comunidade } \\
\text { 2- Alunos da } 8^{a} \\
\text { série } \\
\text { 3- Direção, } \\
\text { professores e } \\
\text { alunos } \\
\text { 4- DEMEC }\end{array}$ & $\begin{array}{l}\text { 1.Próxima } \\
\text { reunião de } \\
\text { pais em } \\
\text { maio } \\
\text { 2. A curto } \\
\text { prazo }\end{array}$ \\
\hline
\end{tabular}

Fonte: Plano de Ação para o Ensino Fundamental da EMEB Alfredo Naime, INDIQUE 2011. 
A mobilização da comunidade aparece como proposta de ação somente para reivindicar a cobertura da quadra, mas, como foi percebido neste trabalho há outras necessidades da escola que poderiam também receber essa atenção. A requisição de adaptações para deficientes reforçam o que foi dito antes e dependem de investimentos.

\subsection{Entrevista da Coordenadora Pedagógica}

Ao longo das entrevistas, as partes foram separadas segundo os arquivos de áudio originais, para facilitar ao leitor que queira encontrar os trechos de falas aqui colocadas nos arquivos digitais de áudio, em anexo neste trabalho.

Entrevista de Luciana Felizardo de Andrade (informações verbais) ${ }^{11}$, Coordenadora Pedagógica da EMEB Alfredo Naime, Andrade (2011), parte 1:

Perguntada sobre o papel da escola na sociedade, Andrade (2011) responde que este é "formar o indivíduo como um todo... não é só a transmissão do conhecimento". Essa formação acontece da seguinte maneira, conforme Luciana: trabalhos de sala de aula; projetos institucionais; alunos ficam de manhã nas aulas curriculares e de tarde nas oficinas (para todas as escolas de período integral de Bebedouro), mas a escola tem autonomia pra escolher as oficinas conforme suas especificidades. Na EMEB Alfredo Naime, quem escolhe quais oficinas serão dadas (exceto algumas oficinas que são obrigatórias, como a OEP (oficina de estudo e pesquisa)) são os alunos numa pesquisa no final do ano. E quem decide quais das oficinas escolhidas pelos alunos serão mantidas ou trocadas é a diretoria (Sueli e Luciana), que geralmente acata as decisões dos alunos, afirma a entrevistada. A coordenadora, contudo, não toca nos assuntos de redução das desigualdades, de equalização de oportunidades ou mesmo de inserção social, focando sua perspectiva para a função social escolar no aspecto individual dos alunos. Mas enaltece o esforço em favorecer o diálogo e não o autoritarismo na rotina escolar quando diz que:

Aqui a gente preza muito assim, pelo diálogo, então a gente conversa muito, os alunos... num tem aquela coisa 'ai a diretoria, diretor...' num tem muito assim aquela coisa que tinha, pelo menos na nossa época e ainda existe escola assim né, que você... às vezes nem via o diretor e quando via era porque aconteceu alguma coisa... aqui não, eles têm muito assim, acesso, pede pra conversar com a gente, eles mesmo vêm reivindicar... então a gente preza muito por isso, pelo

\footnotetext{
11. Informações fornecidas por Andrade em Bebedouro, em 2011.
} 
diálogo entre os alunos, entre os professores... até quando você for conversar com os professores... eles comentam que aqui é muito diferente... até porque é pequeno, acho que por isso também, é uma escola pequena, com poucos alunos, porque se fosse uma escola enorme num dava pro diretor dar atenção, ou mesmo o coordenador, que nós damos pra eles aqui né, aí seria impossível também porque se for ficar atendendo aluno toda hora e dando atenção ele não vai fazer mais nada né, então aqui como é menor nós temos muito isso e até mesmo pra dar o exemplo, pra que eles se sintam mais confiantes e possam ter a escola como amiga, como uma aliada deles e não né, como "ai, eu tô só passando por aqui porque eu tenho que vir, porque eu tenho que aprender, porque eu sou obrigado e pronto' (ANDRADE, 2011).

As oficinas são oportunidades de descobrir talentos, pois pela característica da região, rural, se não fosse esse contato artístico na escola provavelmente o aluno não o teria, aponta Luciana. Esse trabalho de oficinas, diz ela, ajuda os alunos em aspectos que vão além da educação formal e contribuem inclusive para o aprendizado dos conhecimentos curriculares.

"A escola foi adotada por uma empresa", fala a coordenadora pedagógica, referindo-se à uma empresa de suco de laranja que faz parte do projeto "Adote uma Escola", em que mandam uniforme, suco e uma quantia em dinheiro todo mês, a qual serve para o pagamento da psicóloga, conhecida como Cida, que faz acompanhamento psicológico dos alunos. Usa como exemplo o projeto de combate ao Bullying na escola que a Cida participa. A psicóloga auxilia também orientando professores, principalmente os novos, ao lidar com os alunos em seus primeiros contatos, momentos estes que são mais difíceis nesse relacionamento professor/aluno, considera Luciana.

Perguntada sobre o seu entendimento do papel do professor nesse contexto mais dialógico e pouco autoritário defendido por Luciana, ela diz:

\footnotetext{
O professor é o modelo... além de formador, de passar o conhecimento pros alunos... tanto dentro da sala como fora... quando um aluno tem um problema pessoal ele chega a contar pra esse professor e quando tem algum problema ele para a aula né, porque nós já tivemos reuniões em que eles falam 'é aula de geografia, mas surgiu um problema lá', que um aluno tá com um problema e ele percebe aquilo e o aluno quer falar, então pára-se a aula de geografia e vai-se resolver aquele problema com o grupo porque é mais importante isso do que ele continuar dando a aula de geografia e ninguém participar, ninguém vai aprender, se tiver... alguma coisa, algum conflito naquele grupo e ele chegar... porque não basta ele chegar e 'bom dia, boa tarde', ir lá passar a matéria dele e sair, então ele tem que criar uma relação aí dele com os alunos, um vínculo com esses alunos, pra que eles aprendam né, porque a afetividade é muito importante (ANDRADE, 2011).
}

Essa visão revela preocupações acerca da relação do professor com o aluno no sentido de tratá-lo mais como ser humano complexo do que como objeto educativo, em 
que se force a aprendizagem e desrespeite o aluno enquanto sujeito, impondo ao estudante uma relação de poder desigual e prejudicial à sua formação.

Parte 2:

Quando indagada sobre aquilo que concerne à um ensino de qualidade, sobre seu entendimento do que é qualidade de ensino e como ela pode ocorrer, Luciana fala o seguinte:

Pode oferecer qualidade de ensino investindo em formações né, tanto pra funcionários quanto pra professores, em acompanhamento né, pedagógico, e ela investir... em acervos literários pra biblioteca, em acervos de livros, em tecnologia né, um investimento grande, é lousa digital, em computadores, em tudo pra tá auxiliando né, tanto os alunos como os professores né... na alimentação, também (ANDRADE, 2011).

Notou-se nesta fala e no decorrer da entrevista que a Coordenadora Pedagógica tratou de questões de melhorias qualitativas e quantitativas para o sistema escolar neste assunto, mas não abordou ideias de mudança mais profunda, em termos políticos por exemplo, ou daquilo que seria necessário mudar em maior escala para que essas melhorias não soem tanto como desejos muito improváveis, mas direitos humanos inegáveis.

Para a questão da qualidade em termos materiais, de recursos, infraestrutura, entre outros, Andrade (2011) diz que a infraestrutura da escola é "razoável", contando com uma quadra poliesportiva não coberta, salas médias, espaço externo bom, que não é da escola, é público, mas bastante utilizado pelos alunos pela proximidade e tranquilidade do local. Pôde-se observar também a boa conservação geral da escola. Porém, não há sala de artesanato, não há laboratório e a sala de informática já recebeu computadores, mas ainda não está funcionando. A conversa sobre os recursos levou à pergunta sobre a satisfação de Luciana com sua remuneração, ao que responde:

$\mathrm{Na}$ educação é uma defasagem grande, principalmente municipal, porque são muitos anos sem reajuste e... é difícil... tá abaixo do que é pra sobrevivência porque se nós ganhássemos melhor... porque tem professor que dá aula três períodos, aí como que você vai exigir qualidade desse professor? Ele até produz... mas a gente sabe que fica comprometida essa qualidade. Se ele ganhasse um ordenado melhor ele não precisaria desses três períodos (ANDRADE, 2011). 
Parte 3:

Falando agora sobre o que entende por democracia e cidadania, Luciana cita um exemplo de ação democrática — na verdade consultiva no entender deste trabalho — em que, ao invés de reprimir os alunos na ocorrência de um conflito ou problema, eles são consultados individual e coletivamente (observado na prática em sala de aula), tendo espaço e abertura pra dar suas versões, demostrando, como dito anteriormente, tratamento respeitoso que não coloca o aluno em posição inferior ao professor, o que também pôde ser visto pela facilidade de acesso à sala de diretoria que fica sempre aberta e fisicamente próxima das salas, onde os alunos não têm pudor de ir para conversas ou reclamações. A ideia é evitar a punição e avaliar a situação do aluno ou professor em seu contexto, ponderar a vida e os acontecimentos que podem levar aos problemas, comenta Luciana. Esse trabalho também diminui o receio dos estudantes em se posicionarem diante de problemas entre os colegas e entre adultos. Com os pais não é diferente.

Nesse ponto, Andrade (2011) cita espontaneamente o INDIQUE como grande facilitador para transformar as requisições dos pais em ações: "antes não sabíamos bem o que fazer com as coisas que os pais pediam", mostrando que o processo dos indicadores da qualidade na educação tiveram papel essencial nessa articulação da escola com a comunidade, não apenas em termos de comunicação, mas também de ações e rumos para essas ações.

Parte 4:

Em termos de participação e descentralização a coordenadora diz que a escola mudou o sistema de participação na APM, pois perceberam que as perguntas feitas nas reuniões presenciais para saber quem gostaria de participar deixavam algumas pessoas constrangidas em se oferecerem. Assim, passaram a fazer esse levantamento do interesse em participar por meio de comunicados informativos a respeito das atividades e funções da APM, em que as pessoas têm tempo para pensar se querem ou não fazer parte dela, o que, segundo Luciana, teve efeitos positivos sobre a participação na APM.

Luciana aponta também que será inserida no jornal bimestral da escola (que é elaborado por alunos da sétima série com auxílio de um professor responsável pelo projeto e depois enviado às famílias desses alunos) uma página dedicada a informações 
sobre o Projeto Político Pedagógico (PPP) da escola, no intuito de melhorar as informações dos pais em relação ao PPP. Essa ação consta também no relatório do INDIQUE e parece fundamental à democratização no sentido de representar o esforço da escola em não somente buscar maior presença da comunidade na escola, mas levar informação e conteúdo a esses encontros, o que é essencial ao enriquecimento das discussões e consequentemente das ações.

Parte 5:

Quando indagada acerca da relação entre a democracia e a qualidade de ensino, Andrade (2011) diz que "são interligadas, porque se há qualidade de ensino tem que existir a democracia dentro da escola... você tem que dar voz a todos os elementos". A resposta mostra um entendimento de qualidade de ensino ligado à democratização das relações escolares, mas repita-se, não há aprofundamento da coordenadora, ao longo da entrevista, em relação ao que significa essa democratização em termos extra-escolares, ou seja, das relações democráticas pretendidas aos alunos em suas interações com o universo fora do ambiente escolar.

Sem essa relação, ela completa:

(...) você não vai ter essa qualidade, porque aí você nunca vai saber se o que tá acontecendo realmente tá favorecendo a aprendizagem, o conhecimento, como ser humano, se você num der essa oportunidade pra ouvir, pra que haja democracia, pra que as pessoas questionem, pra que as pessoas tenham dúvidas, pra que elas reivindiquem, você num tem como crescer, como melhorar... você num vai saber o que tá bom, o que tá ruim, o que precisa ser melhorado se você num der essa... abertura (ANDRADE, 2011).

O que se viu durante este trabalho foi que a gestão democrática não é aquela que simplesmente "permite" o espaço de manifestação e de ação das pessoas, mas aquela que não inibe esse direito de possuir e também de criar direitos e deveres. A "permissão" não é condenável, vale frisar, mas não é suficiente, caso contrário essa participação seria o que Tragtenberg chamou de co-gestão, a qual configura uma democratização parcial, portanto, uma falsa participação. 


\subsection{Entrevista dos Funcionários}

Entrevista feita com dois funcionários da EMEB Alfredo Naime, juntos (informações verbais) $^{12}$ : Carlos Fregatto (Oficial Administrativo), Fregatto (2011), e Maria Aparecida de Souza (Inspetora de Alunos), Souza (2011), parte 1:

Perguntados a respeito do papel da escola na sociedade, Fregatto (2011) e Souza (2011) mostram opiniões parecidas nesse tema, separando o papel da educação escolar da educação familiar. Maria pensa, sobre o papel da escola, que "...faz parte um pouco da educação das crianças, apesar que a maior parte da educação tem que vim de casa" e Carlos complementa dizendo que "o objetivo da escola... o que a gente vê muito, é instruir, educar, como muita gente fala, educar é de casa, é da família", mas explica o que entende por instruir colocando que “...instruir, se for ver, o indivíduo para que ele se realize como um todo né, porque na escola você não tem só a parte de conhecimento... você aprende, só que você tem a relação com o professor, com os colegas...", no que Maria concorda e completa "o alicerce... é o familiar... a escola acho que vem complementar..."

Sobre a participação deles na administração escolar, foram indagados se são informados sobre esses assuntos e as funções da escola, onde afirmam que sim, recebem informações e instruções de outras questões que não aquelas apenas relacionadas às suas atividades formais de trabalho, caracterizando atitudes não alienadoras de suas condições por parte da diretoria, porém, quando questionados se participam de discussões e reuniões, dizem ter abertura para emitir opiniões, para sugerir, só que participam de muito poucas reuniões, sendo elas apenas as da APM, ocasionalmente. Evidente que isso os deixa muito à margem dos processos decisórios escolares, mas lembram de ter feito parte do movimento de avaliação e proposição feito no INDIQUE, citando-o espontaneamente e sem que houvessem sido indagados especificamente neste quesito, como evento de discussão escolar participativo.

Acerca do papel deles como funcionários, tanto para o que foram contratados quanto para o que exercem de fato, Maria fala que sua função é, principalmente, monitorar todos os alunos no tempo em que ficam fora da sala de aula, cuidar da disciplina, observar se os comportamentos deles estão adequados, atentar para a

\footnotetext{
12. Informações fornecidas por Fregatto e Souza em Bebedouro, em 2011.
} 
prevenção de acidentes, condições de saúde, entre outros, portanto seu trabalho está majoritariamente ligado aos alunos, ainda que tenha contato também com os profissionais escolares e a comunidade. Já Carlos tem no seu cargo atribuições voltadas à parte administrativa, o que faz com que tenha pouco contato com alunos, mas esteja em constante comunicação com a diretoria, os professores e pais, já que boa parte das atividades operacionais rotineiras dependem dele, como impressões, transmissão de informações por telefone, agendamentos, organização de materiais requisitados por professores etc. $\mathrm{O}$ trabalho de ambos tem em comum a característica de fornecer-Ihes amplo conhecimento do dia a dia da escola por acompanharem de maneira bastante próxima o funcionamento escolar, cada qual em sua especificidade, evidentemente, o que os torna imprescindíveis e em boa medida insubstituíveis em suas funções, característica esta que os distancia do trabalhador típico do capitalismo industrial, popularmente conhecido como "trabalhador de chão de fábrica", ao qual se atribui comumente o exemplo do conceito marxista de trabalho alienado, de coisificação do ser humano.

Contudo, como se percebe no discurso de todos os profissionais de educação entrevistados, a valorização dada pela administração pública a eles, notadamente em termos de remuneração, chega a ser constrangedora, conforme os depoimentos que se encontram adiante.

Parte 2:

Souza (2011), ao ser perguntada se sua remuneração é justa, ou adequada às suas necessidades afirma "é pouco... o que eu ganho é pra pagar aluguel, água, luz, telefone... e você come o básico... é só isso, eu num faço mais nada" e exemplifica "...eu adoro ler... mas tenho que pensar mil vezes antes de comprar um livro... porque se for comprar com o salário que eu ganho, num dá... porque tem outras prioridades né."

Outro problema apontado por Carlos e Maria foi da dificuldade de ascensão social. Souza (2011) fala dessa questão do ponto de vista ainda da remuneração, que a limita também de melhorar sua formação e conseguir cargos melhores, já que não pode pagar por um curso superior particular e nem considera a universidade pública, sabendo das barreiras seletivas impostas pelo vestibular, quando declara "...eu tenho um sonho de fazer uma faculdade, só que... faz três ano que eu tô tentando uma bolsa, porque pagar nem pensar, num dá". Carlos recorda que a Prefeitura de Bebedouro e o Departamento de Educação oferecem cursos gratuitos, o que os possibilitaria galgar cargos mais 
elevados, entretanto, isso ocorre somente para professores, não para funcionários, mostrando que as oportunidades geradas ou patrocinadas pelo poder público a essas duas categorias distintas são muito diferentes, salvo uma exceção, de um curso gratuito oferecido pela Prefeitura, porém distante de Bebedouro sem que haja o fornecimento de transporte gratuito, o que, segundo Maria, torna essa única opção dada a eles também inviável.

Fregatto (2011) comenta ainda que "o que falta muito pra gente é... um plano de carreira... por exemplo... o professor começa, depois ele pode ser indicado, tem o sindicato... pra parte de funcionário, principalmente os que trabalham na parte de educação, num tem tanto esse apoio". A afirmação de Carlos levou à outra pergunta lógica, a respeito do sindicato dos funcionários, se ele não existia, se não os representava ou se eram ligados a ele. E ele responde que existe um sindicato, mas que não é específico dos funcionários da educação e sim do funcionalismo público em geral, o que dispersa a sua atuação na defesa dos interesses de determinados trabalhadores, enquanto Maria mal sabia da existência do sindicato. A entrevista indicou, em primeiro lugar, que Carlos e Maria não são engajados ativamente na sindicância, seja ela como for, nem são ligados ao sindicato. Ainda nesse raciocínio, ficou claro que ambos não se consideram inseridos na categoria dos funcionários públicos, enquanto classe, ao separar as demandas do funcionalismo público como um todo de suas necessidades de trabalhadores da educação ${ }^{13}$. Mas as queixas dos entrevistados não se limitam a sindicatos e sim à inexistência de qualquer tipo de organização trabalhista direcionada à defesa dos interesses dos funcionários da educação em Bebedouro, pois nesse quesito dizem estar desamparados. Outra pergunta lógica decorrente dessas queixas foi tentar saber se eles participariam de uma organização assim, que os representasse com mais especificidade, ao que hesitaram, mas responderam que sim, a depender, é claro, das propostas que essa organização tivesse, ressaltou Maria.

Em relação à administração escolar, tanto Carlos quanto Maria opinam que a parte administrativa e a pedagógica devem ser separadas na escola, sendo o cargo de diretor de caráter administrativo, não havendo necessidade do requisito da condição de professor

\footnotetext{
13. Pressupõe-se aqui a existência de classes com interesses opostos e relação de dominação ente elas, conforme já mencionado neste trabalho pela opinião de Tragtenberg e reforçado nas palavras de Wood (2003, p.29), ao contrário do que pretende a "economia política burguesa", a qual "atinge seu objetivo ideológico ao tratar a sociedade como algo abstrato", sem classes antagônicas, determinada por leis naturais acidentais, desvinculadas da história, das relações de poder e das escolhas humanas desses processos.
} 
para a função, já que a parte pedagógica é de responsabilidade dos professores e do coordenador pedagógico. A argumentação de ambos pauta-se pela lógica de funcionamento de uma empresa, em que, segundo eles, dentro de certos departamentos o tempo de serviço tende a levar o trabalhador aos cargos mais altos na hierarquia. As comparações com o setor privado não foram incomuns na entrevista e reforçam o entendimento suscitado ao longo deste trabalho sobre os efeitos da disseminação da ideologia das grandes corporações.

Das condições de trabalho: trabalham nove horas diárias, com uma hora de folga para almoço, de segunda a sexta-feira, e dizem-se satisfeitos com seu ambiente de trabalho, tanto nas relações pessoais, em que mostram e é perceptível o clima amistoso entre os profissionais, quanto nos aspectos de infraestrutura. Recebem alimentação também da escola, comem o mesmo que as crianças, a merenda, que segundo Maria é boa. E parece mesmo ser. A única reclamação de ambos é sobre o calor, já que não há aparelhos ar-condicionado na escola, apenas ventiladores, e a região é bastante quente, principalmente no verão. De fato, sem a necessidade de qualquer aparato meteorológico ou evidência científica, qualquer pessoa que conheça essa região sabe que os tempos quentes, que na verdade predominam no ano, são muito incômodos de suportar sem o arcondicionado. Perguntada se sofre com o calor, a expressão de Souza (2011) não deixa dúvidas: "Vixe!"

\subsection{Entrevista da Diretora}

Entrevista da Diretora da EMEB Alfredo Naime (informações verbais) ${ }^{14}$, Sueli Aparecida Occaso Latorre, Latorre (2011), parte 1:

A opinião de Sueli é de que o papel da escola é formar cidadãos integralmente, nas questões emotivas e sociais também, além dos conteúdos formais, preparar pessoas para a vida. "Antes", diz a diretora, referindo-se à antigamente, ou décadas atrás, a pessoa ascendia socialmente se fosse para a escola, tinha um diferencial, mas atualmente não, as pessoas têm que estudar para sobreviver, para ter cidadania, explica a entrevistada.

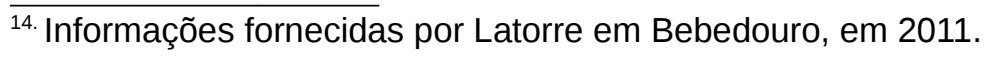


Parte 2:

Complementando as respostas anteriores, Sueli diz que a escola hoje tem também uma função bem mais ampla que a anterior. Antes você apenas ensinava o "ba, be, bi, bo, bu" e não pensava em questões psicológicas e sociais, então a função da escola ampliou, "alguns criticam" hoje, mas "eu" acho que a escola é isso.

Além do ensino formal — pergunta-se a Sueli — qual o papel da escola?

Formar para a sociedade... a criança aprende a viver em sociedade num lugar que é social, porque a família é um lugar social, mas muito pequeno... a primeira vivência na sociedade assim, com mais pessoas, é dentro da escola... é onde você aprende a dividir tudo, a respeitar, ou a não respeitar... então ela tem essa função também, além dos conhecimentos... de ajudar a criança a desenvolver as atitudes, porque é um outro olhar né (LATORRE, 2011).

Sueli fala ainda sobre essa visão de formação no aspecto institucionalizado, pois existem já parâmetros curriculares nacionais que orientam também as escolas nessa direção:

Quando vem os PCNs, os parâmetros curriculares nacionais né, eles já trazem isso aí, quer dizer, além dos conhecimentos básicos nós temos que trabalhar na escola... as atitudes. As relações humanas são através das atitudes, quer dizer, eu saber ler e escrever não me garante que eu vá ser um bom profissional se eu não saber respeitar né, e respeitar não é igual a antigamente que era pelo medo, tem que ser... pelo conhecimento, pela interação mesmo... você saber conversar (LATORRE, 2011).

Parte 3:

Sobre o papel do professor nesse contexto, Latorre (2011) pontua que "ele tem que ser essa pessoa que vai mediar, os conhecimentos, as atitudes né, que vai fazer isso fluir, isso acontecer na vida dos alunos".

Parte 4:

Para isso, coloca Sueli continuando o raciocínio anterior, o professor tem que ter a formação acadêmica, que é importantíssima, mas como ele (professor) tem o papel de mediar, às vezes encontra coisas que desconhece, então tem que ter uma característica muito importante que é a humildade de reconhecer que não sabe, que vai procurar saber e que isso não tira o valor dele, ressaltando que 
...mediar, é você fazer comparações e aceitar que não existe certo e errado e que existe formas diferentes de se pensar, né, e isso precisa ser trabalhado... porque a formação acadêmica num dá isso né, infelizmente nós não temos uma formação acadêmica que vê o professor pensando dessa forma (LATORRE, 2011).

O HTPC, que é o horário de trabalho pedagógico coletivo, serve para discutir a formação continuada dos professores, formação que não tiveram na academia, mas estão tendo dentro da escola, completa a diretora.

O foco da escola parece não estar no professor monológico, mas no dialógico, porém Sueli reconhece a precocidade dessa ideia na escola:

...só que a gente tá engatinhando nisso né, porque ainda a gente não tem uma totalidade, porque pra esse professor, pra gente ter isso mesmo, garantido, a gente precisa também de um professor que acredite nessa postura... e como é feito o processo seletivo nas escolas, num garante que você tenha professores que acreditem... claro que depois é um convencimento, é um trabalho, que você vai falando (LATORRE, 2011).

E exemplifica o que isso significa na prática escolar:

Muitas vezes o professor também, nessa concepção de que 'você ouve o aluno, você ouve o professor', eles acham que quem só tem que ser ouvido é o professor, o aluno não, então você também cria um outro problema, que muitas vezes você escuta conversa dizendo que... 'ah, aqui só, só passa a mão na cabeça do aluno' (LATORRE, 2011).

Questionada se os alunos e os pais conseguem intervir nessa formação, Sueli responde que "os alunos sim... por exemplo, o professor que num escuta eles, eles vem aqui pra gente pontuar, ou, se não, põe na caixa de sugestão". A "caixa de sugestões" mencionada foi a maneira enxergada pela direção de possibilitar a opinião anônima, de fornecer mais uma alternativa de reivindicação aos alunos.

\section{Parte 5:}

Direito de ser ouvido e o dever de ouvir, respeitosamente, mas isso não significa que temos a razão, é preciso respeitar também o "discordar".

Tem muita deturpação na democracia ainda dentro da escola... na questão de representação, quando você pensa em conselhos de representação né, como é o eletivo, o de poder público, como todas as escolas, as instituições, APM, conselho 
de escola, grêmio né, então eles têm muita dificuldade de saber separar que, você na democracia, nem tudo você opina né, você delega a outrem pra ele opinar né... porque não dá pra você ouvir todos dentro de um volume muito grande, né (LATORRE, 2011).

Parte 6:

Em relação à qualidade de ensino, Sueli primeiro responde tendo em vista essa dimensão voltada para o aluno:

Qualidade é ele ser protagonista mesmo... dessa escola né, de ele ser esse ser que reivindica porque, os conhecimentos básicos... a gente vai ter lá no livro didático, se eu pegar o google, sei lá, vou querer pesquisar qualquer coisa, eu vou encontrar, agora, que que é que nós vamos aprender mais? Talvez como vivenciar isso no mundo, né, que é a crise que nós tamo vivendo de... ética né, e de valores aí, você vê tanta violência, tanta... barbárie no mundo, por conta dessa crise... talvez a gente num tá aprendendo nos espaços né, essa vivência democrática, aonde todos são seres, têm direitos, deveres né, mas não tão sabendo se ouvir ou parar pra ouvir e... mudar esse mundo, porque essa qualidade tá muito vinculada a isso (LATORRE, 2011).

Ela comenta sobre as maneiras que essa democracia, essa qualidade, se dão na escola: pela abertura dada aos alunos para reivindicarem coisas na escola; pelo INDIQUE que foi uma das formas de avaliação que eles (pais e alunos) tiveram para se manifestar amplamente; também foram feitas algumas pesquisas de opinião sobre a escola, para alunos e pais, além da "caixa de sugestões" para os mais tímidos... a ideia é criar canais de comunicação, entendendo estes como canais de participação, mas é importante lembrar, pelo que foi levantado no referencial teórico, que somente "dar voz" a esses elementos não basta, a discussão deve incluir as relações de poder entre os sujeitos.

Sobre o acesso e a permanência escolar Sueli é mais pragmática, mostrando certa concordância com a obrigatoriedade legal para evitar a omissão familiar da sua responsabilidade de matricular e manter os filhos por determinado período de tempo na escola:

Essa questão do acesso e da permanência, hoje, na escola... ela num tá mais assim tão democrática, assim 'eu quero, eu não quero' né, eu acho que isso tem que ficar claro, o acesso e a permanência, ele é um quesito que é obrigatório né, então esse aí num dá pra gente falar da questão democrática, ele é obrigatório, então as vagas existem dentro da nossa escola porque é uma escola pequena... a obrigatoriedade não se abre mão, porque é uma legislação e a permanência também não... porque se você deixa aberto isso também... nós vamos ter umas omissões, de famílias aí que não vão mandar alunos (LATORRE, 2011).

Como algumas coisas são obrigatórias, por lei, e os alunos têm que ir às aulas e 
permanecer na escola, principalmente na Alfredo Naime, que é de período integral, a escola, para ter qualidade, tem que ser prazerosa, comenta, permitindo aos alunos escolher, dentro do possível, as atividades que preferem.

\title{
Parte 7:
}

Perguntada sobre a administração escolar e o papel do gestor: o que é, significa, como se pratica, para quem e por quem? Sueli responde que:

\begin{abstract}
A administração escolar, ela recai sobre o papel do diretor né, que é o quê? É gerir, fazer essa máquina, vamo pensar... funcionar né, de uma maneira mais assim... efetiva né. É você propiciar pra que todos consigam mesmo trabalhar nesse ambiente de maneira organizada e... que consiga ter um objetivo... um objetivo que seria o ensino e a aprendizagem dos alunos né... porque o nosso recurso... nosso produto é o ensino e a aprendizagem né, e que aí é um pouco mais difícil de lidar com tudo isso porque você pensa que você tem que formar pessoas... é diferente de você montar um produto, né. Por isso que a gente caba tendo que assim é, pensar em várias outras questões, dessa questão da democracia, dessa questão do papel de cada um né... precisa ter um envolvimento muito grande (LATORRE, 2011).
\end{abstract}

Ao ser indagada a respeito dos requisitos, as características que os gestores de ensino precisam ter para que essa administração voltada para o ensino e a aprendizagem ocorra, a diretora enaltece o acompanhamento das atividades e a propensão ao diálogo, respondendo que:

Os requisitos, é claro que assim, alguns são de organização mesmo né, você tem
que pegar, organizar isso, organizar aquilo, tal, mas assim, o requisito maior numa
escola eu acho que é o acompanhamento, é você ir vendo, fazendo essas
observações 'olha, isso aqui num tá legal, isso aqui vamo ver como que a gente
pode fazer diferente pra melhorar né...' eu acho que o quesito maior quando você
lida com administração escolar, que você tá lidando com pessoas, porque é aquilo
que eu falei pra você, a gente não lida com um produto né, com pessoas é
acompanhamento, é conversa, é diálogo, né... se num tiver esse foco, fica difícil
de administrar... porque também se você não tiver o diálogo você também não
ouve... então você fica aquela coisa de autoritária... e a gente procura não ser isso
(LATORRE, 2011).

Da descentralização, nas dimensões pedagógicas, administrativas e financeiras, observou-se que ainda há muito a se fazer, já que essas dimensões ainda ficam sob a tutela e a responsabilidade, quase que totalmente e em última instância, da Diretora Sueli e da Coordenadora Pedagógica Luciana. Alguns assuntos fundamentais à descentralização nessas dimensões foram levantados no INDIQUE, como: a necessidade de conhecimento, definição e atualização, por todos os atores envolvidos com a escola, 
do Projeto Político Pedagógico; discussão e participação democrática sobre a utilização dos recursos financeiros e; o a ampliação do acesso a informações de avaliação da escola.

Da questão sobre a participação, Latorre (2011) diz que cada pessoa tem uma visão sobre o que é escola de qualidade e que a compreensão dos pais pode não ser a mesma dos gestores nesse quesito. Cita então alguns avanços da escola nos últimos anos na tentativa de reunir e considerar essas divergências, entre eles: consultaram os vários atores escolares na elaboração do plano gestor para o quadriênio de 2008 a 2011; organizaram, com assessoria do CENPEC (Centro de Estudos e Pesquisas em Educação, Cultura e Ação Comunitária), seminários que serviram de canal alternativo de comunicação com a comunidade, por sua abordagem diferenciada; por fim, passaram pelo INDIQUE em 2010, onde foi feito um grande encontro das pessoas da comunidade escolar para a discussão de várias questões referentes à escola que ajudaram a construir, coletivamente, um plano de ação a partir dos pontos debatidos nesse encontro, pontos estes que serão detalhados adiante neste trabalho. Apesar de achar que a participação da comunidade na escola é boa, em termos gerais, Sueli destaca três problemas de participação: a falta de interesse de algumas pessoas em participar dos processos escolares relevantes, talvez por falta de noção da importância dessa adesão e de conhecimento sobre os mecanismos de participação; a dificuldade de acesso e transporte, com frequência, de boa parte da comunidade para a escola, por sua característica rural e; a "correria" da rotina e do trabalho escolares, já repletos de tarefas e exigências que quase não deixam tempo livre para atividades em que a comunidade participe.

Sobre os benefícios trazidos pelo INDIQUE, notadamente aos colegiados neste caso, Sueli comenta:

...agora nós estamos fazendo um movimento diferente, porque antes a gente ouvia
e num tava sabendo muito bem o que fazer com essas informações. Hoje nós
traçamos metas. Então, por exemplo, uma coisa que a gente observou... com o
INDIQUE... é eles (os pais dos alunos) não saberem o papel dos conselhos,
porque, vamo supor, nós temos os colegiados dentro da escola, mas funcionar
como deveria ainda tá faltando, porque você chama um pai ele geralmente num
vem pra reunião né... às vezes ele até opina, mas ele nem sabe o que que ele tá
opinando... ele não tem claro ainda que ele está representando esses outros pais.
Os pais não têm claro que ao eleger... tá elegendo alguém pra representá-lo,
então isso é um trabalho que a gente vai ter que começar a intensificar, né
(LATORRE, 2011).

Os colegiados constituídos são: a APM (Associação de pais e mestres), a qual, diz 
Sueli, também ainda não conhece bem o seu papel; o Conselho Escolar, idem e; o Grêmio Estudantil, que Sueli considera um "entrave" à tentativas democráticas com os alunos, pois a participação dos estudantes no grêmio restringe-se à requisição de atividades de lazer, já que não exercem também o papel de colaboradores do processo de ensino-aprendizagem. Ao menos duas constatações podem ser feitas aqui: se a APM, o Conselho Escolar e o Grêmio Estudantil não sabem bem seu papel isso mostra, pelo menos, que a escola foi falha em elucidá-los sobre isso e; a requisição de atividades de lazer pelo Grêmio Estudantil é legítima e compreensível, afinal, é natural crianças que adolescentes queiram lazer.

Partes 7 e 8:

Exemplo de possível ganho de autonomia e menor intervenção externa na EMEB Alfredo Naime, conforme lembrado por Mendonça (2000, p.416), diz respeito ao Regimento da escola em que, como medida imediata após o INDIQUE, começará a ser reescrito com a participação do conselho escolar, o qual possui composição igualitária entre comunidade (basicamente pais e alunos) e escola (professores, gestores e funcionários), segundo diz a diretora Sueli:

Nós vamos começar a reescrever o Regimento da escola... as regras mesmo de convivência da escola. Então, pra isso, a gente... tá fazendo uma minuta pra passar pra supervisão, a supervisão vai avaliar, vai ver se tá de acordo pra ver se não tem nada de ilegalidade pra depois a gente trazer junto dos pais, discutir com eles pra aprovar e eles serem esse mediador sabe, que tá participando desse processo (LATORRE, 2011).

Já o orçamento é restrito às quantidades ditadas pelo DEMEC (Departamento Municipal de Educação e Cultura de Bebedouro), o qual, por ser Departamento e não Secretaria, não possui autonomia administrativa em relação à Prefeitura e depende do aval do prefeito, em última instância, para a autorização de distribuição dos seus recursos, comenta Latorre (2011). Pode-se dizer, a partir dos relatos obtidos com todas as entrevistas, que a quantia de recursos estipulada pelo Departamento para a Alfredo Naime é minimamente suficiente para que as atividades escolares ocorram, mas está longe de ser satisfatória, visto que partes consideradas importantes dessas atividades, como a contratação de uma psicóloga, a complementação alimentar da merenda, dos uniformes e até de materiais didáticos, só são viáveis, principalmente, graças a outras 
duas fontes de recursos, uma pública, que é o PDDE (Programa Dinheiro Direto na Escola, do governo federal) e outra privada, por meio do programa "Adote uma Escola", via uma grande empresa do setor de insumos agrícolas que possui instalações em Bebedouro. Ainda há questões importantes não resolvidas nem por verbas complementares, como: parte do transporte; instalações relevantes de infraestrutura como laboratório e sala de informática e; a remuneração considerada insatisfatória, pra dizer o mínimo, dos profissionais escolares. Some-se a isso o fato de que a maior parte das verbas destinadas à escola tem como parâmetro o número de alunos, mas não considera o período de atividade escolar, o que se torna um agravante, principalmente para a Alfredo Naime, por ser uma escola de período integral com número de alunos relativamente baixo, no total e por sala de aula. Assim, o planejamento orçamentário da própria escola se dá apenas numa pequena quantia de recursos para cobrir despesas eventuais

Partes 9 e 10:

Sueli acha salutar a autonomia pedagógica parcial, no sentido de seguir linhas pedagógicas que foram historicamente construídas no mundo e no Brasil, portanto seguir certos parâmetros gerais de conteúdos, o que não impede a liberdade de a escola escolher também seus próprios caminhos, ou seja, a maneira pela qual esses conteúdos serão abordados. A diretora, ao mesmo tempo que reconhece a influência hierárquica no planejamento pedagógico, não demonstra críticas a esse modelo burocrático instituído e dá a entender que a ação democrática ocorra nas formas de abordagem pedagógica e não nos conteúdos. 


\section{CONSIDERAÇÕES FINAIS}

Antes de qualquer consideração a respeito da qualidade do ensino, na dimensão da gestão democrática, faz-se necessário dizer que, por melhores que sejam as intenções e ações, administrativas ou pedagógicas, dos profissionais escolares da EMEB Alfredo Naime, elas esbarram em pelo menos três questões fundamentais ao tema aqui exposto: a questão da escassez de recursos financeiros, onde o investimento da Prefeitura de Bebedouro atende às necessidades mínimas de funcionamento da escola, mas não satisfaz condições que possam levar à qualidade no ensino, como a má remuneração de todos os trabalhadores da escola, que os afeta diretamente no desempenho de suas atividades e, consequentemente, impede ou dificulta que eles as exerçam bem, restringindo também as importantes melhorias em infraestrutura que a escola precisa; a questão da falta de tempo, visto que a rotina de trabalho dos profissionais escolares é sobrecarregada de tarefas e não é por acaso que no Plano de Ação aparecem reivindicações pela comunidade de contratação de mais pessoas para a escola, onde os dizeres de um professor do ciclo I são emblemáticos, pois "exige-se demais, mas num dá tempo de pensar... de executar", de modo que não resta tempo para se dedicarem com a devida atenção às dimensões pedagógicas, políticas e democráticas, que chegam a ser discutidas, mas raramente postas em prática e; a questão da falta de autonomia da escola, não apenas do diretor, mas de todos os funcionários, que, como foi mostrado neste trabalho, não podem sequer instalar os computadores que já foram adquiridos e estão na escola há quase dois anos.

Ainda que fiquem evidentes essas limitações da escola, a qualidade e a gestão escolar democrática não se resumem a isso. É essencial avaliar aqui um aspecto ideológico que pôde ser observado nas entrevistas e conversas com todos os atores escolares e principalmente com o corpo gestor da Alfredo Naime. Mesmo com discurso e comportamento coerentes e pró democráticos, os quais não se pretende aqui desvalorizar, pelo contrário, a diretora e a coordenadora pedagógica não demonstram a mesma preocupação para além dos muros da escola, quando não reconhecem, ou não enxergam, as desigualdades sociais e de relações de poder no contexto em que a escola está inserida, nem posicionam o papel da escola como confrontador dessas realidades excludentes. Essa característica pode ser entendida como próxima do que Saviani (2008, p.6) chamou de "pedagogia nova" onde o eixo de preocupação da qualidade de ensino passa do âmbito político, relativo ao conjunto da sociedade, para o âmbito técnico 
pedagógico, relativo ao interior da escola.

A participação da comunidade é outra dimensão criticável da escola estudada. Notou-se durante a pesquisa que a direção procura várias maneiras de aproximar os pais da escola, informando-os sobre os acontecimentos e conteúdos pertinentes desta sempre que possível e exaltando a relevância da presença e acompanhamento deles. Como se não bastassem esses esforços da direção, o tamanho do Povoado de Andes, o fato de que a maioria das famílias possui carros, segundo os professores, e os horários marcados para encontros e reuniões, quase sempre fora do horário comercial, facilitam a participação dos pais nesses eventos. Mas, assim mesmo a adesão é baixa, dizem os professores. Todavia, os próprios professores parecem ter uma possível solução a esse problema, quando afirmam que basta haver festividade ou comida no encontro que a comunidade aparece. Ora, se fatores simples como a presença de alguns comes e bebes, ou música, são suficientes para melhorar a participação e, se esta é desejável, há que se ponderar um formato mais festivo ou gastronômico para as reuniões.

Outro fator relevante acerca da gestão democrática do ensino concerne ao modo de provimento do cargo de diretor. O caso da EMEB Alfredo Naime nesse quesito é peculiar, porque possui as características de duas maneiras consideradas paradoxais, em termos democráticos, neste trabalho: a indicação política pelo DEMEC para cargo de confiança, meio pelo qual Sueli foi contratada e; a eleição, pois os relatos das pessoas ligadas à escola mostram que a indicação política veio após a legitimação de Sueli na comunidade, ou seja, ela foi informalmente indicada pelo Povoado de Andes à função e essa vontade popular vem sendo legitimada e perpetuada pelas autoridades públicas por mais de dez anos.

Na mesma medida em que foi crucial apontar as principais restrições da escola e críticas a seu respeito tendo em vista o objetivo desta dissertação, também é vital reconhecer ao menos uma limitação deste trabalho nesse sentido, pela sua proposta, onde o debruçar do estudo sobre a escola, ainda que tenha levantado questões referentes à suas instituições superiores e suas conjunturas, não permitiu avaliar com maior profundidade as estruturas de poder extraescolares, tão marcantes nas gestões das escolas.

Por fim, a despeito de todas as limitações mencionadas para a escola, em sua capacidade de oferecer qualidade de ensino numa perspectiva de gestão democrática, para o INDIQUE e para este estudo, algumas afirmações ainda podem ser feitas. Em 
primeiro lugar, que as compreensões e as ações dos atores escolares sobre educação e administração - com algumas ressalvas trazidas ao longo das análises neste trabalho demonstraram uma gestão que percorre caminhos democratizantes em vários sentidos, principalmente no que diz respeito ao gradativo aumento de participação direta dos diversos atores escolares (notadamente após o INDIQUE), fenômeno este aqui compreendido como elemento possibilitador de alcance do ideal da autogestão e, por essa razão, pode-se dizer que rumam, sim, à qualidade no ensino enquanto dimensão desta. Em segundo lugar, que ficou nítida a importância do INDIQUE nesse processo ao levar a discussão e a reflexão dessas questões educacionais até a comunidade e da comunidade de volta para a escola. Também ficaram claros os avanços alcançados pela avaliação dos Indicadores da Qualidade na Educação desde as atividades corriqueiras até questões ideológicas e subjetivas dos envolvidos, os quais já podem ser percebidos pouco tempo depois de sua aplicação, mostrando que o INDIQUE é efetivamente um mecanismo democrático de avaliação, capaz de resultados muito mais efetivos do que gerar classificações numéricas às escolas, que é promover uma rica reflexão coletiva para o estabelecimento dos meios e fins de cada escola. 


\section{BIBLIOGRAFIA}

AÇÃO EDUCATIVA; UNICEF; PNUD; MEC/INEP. INDIQUE: Indicadores da qualidade na educação. 3 ed. São Paulo: Ação Educativa, 2007. Disponível em: $<$ http://www.acaoeducativa.org.br/downloads/indicadores/Indicadores2007Miolo.pdf > . Acesso em 05 Dez. 2009.

BEBEDOURO. Plano Gestor 2008/2011 da EMEB Alfredo Naime. DEMEC, 2008.

BENEVIDES, M.: Cidadania e direitos humanos. São Paulo, IEA/USP. Disponível em: $<$ http://www.iea.usp.br/artigos/benevidescidadaniaedireitoshumanos.pdf $>$. Acesso em 29 Jun. 2010.

BRASIL. Constituição (1988). Constituição da República Federativa do Brasil. Brasilia, DF: Senado Federal, 1988.

BRASIL. Lei n. 9.394, de 20/12/1996. Estabelece as diretrizes e bases da educação nacional. Diário Oficial da União. Brasília, 1996.

BRASIL. Ministério da Educação. Plano de Desenvolvimento da Educação. Brasília, DF: MEC, 2007. Disponível em: <http://portal.mec.gov.br/arquivos/pdf/livromiolov4.pdf>. Acesso em 19 Jan. 2007.

BRASIL. Ministério da Educação. In: Portal do Ministério da Educação. Disponível em: $<$ http://portal.mec.gov.br/index.php/?option=com_content\&view=article\&id=12320 > . Acesso em 02 Jul. 2011.

BORDIEU, P. Escritos de Educação. 9. ed. Rio de Janeiro: Vozes, 2007.

CAMPOS, M. M. A qualidade da educação em debate. Relatório do Observatório da Educação, 2000.

CARREIRA, D.; PINTO, J. M. R. Custo aluno-qualidade inicial: rumo à educação pública de qualidade no Brasil. São Paulo: Global, 2007.

CHIAVENATO, I. Administração: Teoria, Processo e Prática. São Paulo: Elsevier, 2009.

DAVEL, E.; ALCADIPANI, R. Estudos críticos em administração: a produção científica brasileira nos anos 1990. RAE-revista de administração de empresas, v. 43, n. 4, p. 72-85, out./dez. 2003.

DEMO, P.: Educação e Qualidade. 11. ed. Campinas: Papirus, 2007.

DEMO, P. Introdução à metodologia da ciência. São Paulo: Atlas, 2008.

DESSLER, G. Administração de recursos humanos. 2. ed. São Paulo: Prentice Hall, 2003.

DIEHL, A. A.; TATIM, D. C. Pesquisa em ciências sociais aplicadas: métodos e técnicas. São Paulo: Pearson Prentice Hall, 2004. 
DOURADO, L.F. A escolha de dirigentes escolares: políticas e gestão da educação no Brasil. In: FERREIRA, N.S.C. (Org.). Gestão democrática da educação: atuais tendências, novos desafios. 5. ed. São Paulo: Cortez, 2006. p. 77-95.

DOURADO, L. F.; OLIVEIRA, J. F. de. A qualidade da educação: perspectivas e desafios. Cad. CEDES [online]. 2009, vol.29, n.78, pp. 201-215. Disponível em: $<$ http://www.scielo.br/scielo.php?script=sci arttext\&pid=S010132622009000200004\&lng=en\&nrm=iso>. Ācesso em 15 dez. 2009.

DOURADO, L.F.; OLIVEIRA, J.F.; SANTOS, C.A. A qualidade da educação: conceitos e definições. Série Documental: Textos para Discussão, Brasília, DF, v. 24, n. 22, p. 5-34, 2007. Disponível em: <http://www.redecaes.com.br/luiz.html>. Acesso em 13 jul. 2010.

DOURADO, L. F. Políticas e gestão da educação básica no Brasil: limites e perspectivas. Educ. Soc. [online]. 2007, vol.28, n.100, pp. 921-946. Disponível em: $<$ http://www.scielo.br/scielo.php?script=sci arttext\&pid=S010173302007000300014\&lng=en\&nrm=iso >. Acesso em 20 mar. 2011.

FREIRE, P. Pedagogia da autonomia. 23 ed. São Paulo: Paz e Terra, 2002.

FREIRE, P. Pedagogia da Esperança: um reencontro com a Pedagogia do Oprimido. 13. ed. São Paulo: Paz e Terra, 2006.

GHANEM, E. O que pode significar a gestão da educação. FEUSP, Ação Educativa. Disponível em <http://www.hottopos.com/videtur20/elie.htm>. Acesso em 07 Mar. 2008.

GILES, T. R. História do existencialismo e da fenomenologia. São Paulo: EPU, 1989.

GRAMSCI, A.: Maquiavel, a Política e o Estado Moderno. 5. ed. Rio de Janeiro: Civilização Brasileira 1984.

HOLANDA, S. B. Raízes do Brasil. 18 ed. São Paulo: José Olympio, 1986.

LIMA, L. C. A Escola como Organização Educativa: uma abordagem sociológica. São Paulo: Cortez, 2001.

MARX, K. Manuscritos Econômico-Filosóficos. São Paulo: Martin Claret, 2002.

MAXIMIANO, A. C. A. Teoria Geral da Administração. 4. ed. São Paulo: Atlas, 2004a.

MAXIMIANO. Introdução à Administração. 6. ed. São Paulo: Atlas, 2004b.

MENDONÇA, E. F. A regra e o jogo: democracia e patrimonialismo na educação brasileira. Campinas: FE/UNICAMP, 2000.

MOTTA, F. C. P. Teoria das Organizações: evolução e crítica. 2. ed. São Paulo: Pioneira Thomson Learning, 2001.

MOTTA, F. C. P. et al. Participação e participações: ensaios sobre autogestão. São Paulo: Babel, 1987. 
OLIVEIRA, R. P. ; ARAUJO, G. C.: Qualidade do ensino: uma nova dimensão da luta pelo direito à educação. Revista Brasileira de Educação, Rio de Janeiro, n. 28, 2005.

PARO, V. H. Gestão democrática da escola pública. 3. ed. São Paulo: Ática 2001a.

PARO, V. H. Administração escolar: introdução crítica. 10. ed. São Paulo: Cortez 2001b.

PARO, V. H. Gestão escolar, democracia e qualidade do ensino. São Paulo: Ática 2007.

PARO, V. H. Educação como exercício de poder: crítica ao senso comum em educação. São Paulo: Cortez, 2008.

PAES DE PAULA, A. P; Por uma nova gestão pública: limites e potencialidades da experiência contemporânea. Rio de Janeiro: FGV, 2005.

PAES DE PAULA, A. P; Teoria crítica nas organizações. São Paulo: Thomson Learning, 2008.

PAES DE PAULA, A. P. et al. A tradição e a autonomia dos estudos organizacionais críticos no Brasil. RAE-revista de administração de empresas, v. 50, n. 1, p. 10-23, jan./mar. 2010.

PEREIRA, L. C. B. ; SPINK, P. Reforma do Estado e administração pública gerencial. 4. ed. Rio de Janeiro: FGV, 2001.

PINTO, J. M. R.: A política recente de fundos para o financiamento da educação. Educ. Soc., Campinas, v. 28, n. 100, 2007a.

PINTO, J. M. R.: O financiamento do PDE. Em Questão, Ação Educativa, São Paulo, v. 4, 2007b.

RAMOS, A. G. Introdução crítica à sociologia brasileira. Rio de Janeiro: Editorial Andes Ltda., 1957.

RAMOS, A. G. A nova ciência das organizações: uma reconceituação da riqueza das nações. Rio de Janeiro: FGV, 1981.

RAMOS, A. G. Administração e contexto brasileiro: esboço de uma teoria geral da administração. 2. ed. Rio de Janeiro: FGV, 1983.

ROMANELLI, O. O. História da educação no Brasil, 1930-1973. Petrópolis: Vozes, 1978.

SANDER, B. Educação na América Latina: Identidade e globalização. Educação, Porto Alegre, v. 31, n. 2, 2008.

SANTOS, M. Pensando o Espaço do Homem. 5. ed. São Paulo: Edusp, 2007.

SAVIANI, D. O plano de desenvolvimento da educação: análise do projeto do MEC. Educ. Soc., Campinas, v. 28, n. 100, 2007. 
SAVIANI, D. Escola e democracia. Edição Comemorativa. Campinas: Autores Associados, 2008.

SÃO PAULO. Fundação Sistema Estadual de Análise de Dados. Perfil Municipal de Bebedouro. SEADE 2011.

SOUZA, J. A gramática social da desigualdade brasileira. Revista Brasileira de Ciências Sociais, São Paulo, v. 19, n. 54, 2004.

TRAGTENBERG, M. Sobre Educação, Política e Sindicalismo. São Paulo: Cortez, 1990.

TRAGTENBERG, M. Burocracia e Ideologia. 2. ed. São Paulo: Ática, 1992.

TRAGTENBERG, M. Administração, poder e ideologia. 3. ed. São Paulo: Editora UNESP, 2005.

VIEIRA, S. L. et al. Gestão da Escola: Desafios a Enfrentar. Rio de Janeiro: DP\&A, 2002.

WEBER, M. A ética protestante e o "espírito" do capitalismo. São Paulo: Companhia das Letras, 2004.

WOOD, E. M. Democracia contra capitalismo: a renovação do materialismo histórico. São Paulo: Boitempo Editorial, 2003. 
ANEXOS 
Roteiro das entrevistas

Papel da escola:

1. O que você pensa sobre o papel da escola na sociedade, a estrutura didática (conteúdo e forma de ensino - projeto pedagógico)

2. O que você pensa sobre a qualidade de ensino?

3. Além do ensino formal, ensinar a ler e escrever, o que mais é importante na educação?

4. Nesse contexto, qual o papel do professor?

5. Qual você pensa que deve ser a formação do professor para isso?

Democracia:

1. Qual a sua visão sobre o significado de democracia? Cidadania, conhecimento de direitos e deveres, criação de diretos e deveres etc.

2. Qual a relação entre a democracia e a qualidade do ensino?

3. Nesse sentido, como formar o cidadão? Garantir acesso, universalização e permanência ao ensino?

Administração escolar:

1. O que é, como se pratica, para quem e por quem?

2. Descentralização: há representação de conselhos e colegiados? Quais seus papéis? E o alcance de suas decisões?

3. Como você vê a participação: pais, alunos, comunidade, funcionários?

4. Os recursos disponíveis, de remuneração, de infraestrutura, de manutenção e melhoria, entre outros, são suficientes ou satisfatórios?

Autonomia:

1. Planejamento e orçamento vem do Departamento de Educação (DEMEC) ou são feitos pela própria escola? Qual parte cabe à escola?

2. O Regimento Escolar foi elaborado por quem? 